\title{
Note
}

\section{Filling the Void: Judicial Power and Jurisdictional Attacks on Judgments}

In any system of law there is a tension between the goal of resolving disputes quickly and finally and that of assuring that the resolutions so reached will be perceived as "fair" or "just." The recognition that there must be agencies with power to resolve disputes has always been tempered by the fear of arbitrary exercise of that power. This tension has been reflected in judicial attitudes toward the relationship between the jurisdiction of a court and the finality of its judgments. For over three centuries it has been black-letter law that the judgment of a court without jurisdiction over the subject matter of the action before it ${ }^{1}$ is null and void in its entirety. ${ }^{2}$ This "voidness doctrine" has served to check excesses of judicial power, but only at some real cost to finality; to say a judgment is void is to deny its existence and a fortiori to deny that the underlying dispute has been resolved. As cases have arisen in which the demands of finality appeared more important than the original excess of jurisdiction, courts have developed doctrines to counter the voidness doctrine. ${ }^{3}$ In this century the exceptions have become the rule, but the voidness doctrine has not disappeared; courts and commentators alike have acknowledged at least a small place for it.4

This Note argues that the voidness doctrine deserves no place in

1. "Jurisdiction over the subject matter of an action," for the purposes of this Note, shall encompass all questions of a court's power orer an action or class of actions except the power to bind specific parties to judgment, which is referred to as "jurisdiction over the person," or personal jurisdiction. Subject-matter jurisdiction as used here thus comprehends questions such as the types of cases a court may hear (e.g., criminal, divorcc, contract actions with a limited amount in controversy), what relief it may award, what things it can affect, and so forth. See generally F. JAMEs, Civil Procedure 536-37, 621-36 (1965); D. Louisell \& G. Hazard, Cases and Materials on Pleading and Proceduri 269-70, 477-83 (3d cd. 1973); RESTATEMENT of JUDGMENTs $\$ \$ 4-8$ (1942) [hereinafter cited without cross-reference as First Restatement]. A rough but useful test for distinguishing between the two broad categories of jurisdiction is that a question is one of personal jurisdiction if it would be obviated by timely service of valid process in some specified geographic area, and is otherwise one of subject-matter jurisdiction.

2. The Marshalsea, 10 Co. Rep. 68b, 77 Eng. Rep. 1027 (K.B. 1613).

3. See pp. 169-71 infra.

4. See pp. 171-81 infra.

\section{4}


modern American law. Part I examines the development of the doctrine in England and the United States and concludes that, when viewed in light of the revolution in American procedural law in this century, the doctrine's historical justifications are no longer persuasive. Part II then develops a theory of judicial power based directly on society's need for final resolution of disputes. Under this theory questions of jurisdiction do not affect issues of judicial power; once a dispute is settled, the fact of settlement is more important than the identity of the court that acted. Part III analyzes the cases central to the voidness doctrine in terms of the theory developed in Part II and in terms of the goals the cases purport to advance. This analysis renders the conclusion that the cases were poorly decided on their own terms and that there is, as a consequence, no legitimate obstacle to implementation of the theory of Part II. Finally, Part IV synthesizes the theory of Part II into a simple rule for dealing with attacks on judgments.

\section{Development of the Voidness Doctrine}

\section{A. Origins}

The concept of jurisdiction over the subject matter of an action grew up in England as a tool of the royal, or "superior," courts in their power struggle with the local and ecclesiastical courts. ${ }^{5}$ The royal courts-King's Bench, Common Pleas, and Exchequer-had nationwide jurisdiction and asserted power to treat proceedings in a local court not having jurisdiction as null and void from their inception. ${ }^{6}$ Such proceedings were coram non judice-"before one not a judge."

5. See generally Dobbs, The Decline of Jurisdiction by Consent, 40 N.C.L. REv. 49 (1961) [hereinafter cited as Consent].

6. The leading case is The Marshalsea, 10 Co. Rep. 68b, 77 Eng. Rep. 1027 (K.B. 1613). See Consent, supra note 5, at 67-69. For an excellent and comprehensive treatment of the development of the English voidness doctrine, as well as a discussion of its early impact in the United States, see I J.W. SMith, A Selection of Leading Cases ox Various Branches of the Law $800-48$ (5th Am. ed. J. Hare \& J. Wallace 1855) (from 3d Eng. ed. H. Keating \& J. Willes 1849) (lst ed. London 1837) [hereinafter cited as SMrru's LEAding Cases].

7. This assertion of power was made in two ways. First, the royal court could issue a writ of prohibition to the lower court, forbidding the lower court from proceeding further with an action over which it purportedly had no jurisdiction. This method was used extensively to curb the powers of the ecclesiastical courts. E.g., Harrison v. Burwell, 2 Ventr. 9, 86 Eng. Rep. 278 (K.B. 1670) (writ lies to prevent erroneous dissolution of valid marriage); see Consent, supra note 5 , at $60-61$ \& $\mathrm{n} .58$ (citing cases). Second, once the judgment had been executed, the defendant could sue the judge who entered it and the officer who exccuted it in trespass; liability would hinge on whether the judge and officers could sustain a defense of immunity, i.e., whether the judgment was valid or void. E.g., Crepps v. Durden, 2 Cowp. 640, 98 Eng. Rep. 1283 (K.B. 1777); The Marshalsea, 10 Co. Rep. 68 b, 77 Eng. Rep. 1027 (K.B. 1613). 
contrast, there seems to be no case in which the judgment of one of the superior courts was held to be void. ${ }^{8}$ The English voidness doctrine was used exclusively to subject the local and ecclesiastical courts to royal supervision.

Upon importation into the United States the doctrine expanded greatly, a result traceable for the most part to the existence of competing sovereignties in a federal union. There were no courts exactly comparable to the English royal courts: the national courts had explicitly limited jurisdiction and the state courts, although usually possessing general common law powers, ${ }^{9}$ did not have nationwide process. ${ }^{16}$ It is thus not surprising that the voidness doctrine took on an added dimension in the United States in the nineteenth century. In purely intrastate cases, as in England, the doctrine was used only to control

8. There was apparently general agreement that such a judgment could be held to be void, at least if a royal court issued a writ that it had no authority to issue. Gosset v. Howard, 10 Q.B. 411, 453, 116 Eng. Rep. 158, 173 (Exch. Ch. 1847); The Marshalsea, 10 Co. Rep. 68b, 76b, 77 Eng. Rep. 1027, 1039 (K.B. 1613). In Gosset, however, Baron Parke went so far as to say

[i]t appears, indeed, that, if a writ of a Superior Court expressed no cause at all, it would be legal ....

... In case of an improper exercise of the power of attachment by a Court of Law or Equity,... . there can be no appeal: the only remedy is by application to the sense of justice of each Court: and it would be improper to suppose that any one of them would be more likely to abuse the power, or less likely to grant redress, than another.

10 Q.B. at $455,457,116$ Eng. Rep. at 174. See also Consent, supra note 5, at 77 n.145. Prigg v. Adams, Carthew 274, 90 Eng. Rep. 762 (K.B. 1691) (digested at 2 Salk. 674, 91 Eng. Rep. 573), illustrates Baron Parke's statement. In that case a judgment for five shillings rendered by a royal court, the Court of Common Pleas, was sustained against an attack based on an Act of Parliament granting a local court exclusive jurisdiction of actions for less than 40 shillings and explicitly declaring any judgment of a royal court for such less amount to be void. Because the prior action was one normally cognizable in the Court of Common Pleas, the judgment was held to be "voidable" only, i.e., subject to attack only by motion to vacate addressed to the rendering court, or by writ of error. The scemingly absolute invulnerability of the judgments of the superior courts, however, held only at law. Equity could and did intervene on a number of grounds to enjoin enforcement of judgments. Such intervention worked on the parties and did not in principle reach the validity vel non of the judgment. See p. 170 \& notes 31-34 infra.

9. But there were, for example, no courts of equity in Pennsylvania at the time of the Revolution, and jurisdiction to award equitable remedies was conferred by statute only. See, e.g., Davis v. Gerhard, 5 Whart. 466, 470 (Pa. 1840); Pollard v. Shaaffer, 1 Dall. 210, 213 (Pa. 1787). But see id. (oath of judges bound them to "determine causes according to equity as well as the positive law; equity being a part of the law").

10. See p. 168 and notes 14 \& 16 infra. Congress has not often granted nationwide process to federal courts, but it has done so in some circumstances, e.g., 15 U.S.C. $\$ 78 a a$ (1970) (actions under Securities Exchange Act of 1934); 28 U.S.C. $\$ 2361$ (1970) (interpleader actions under 28 U.S.C. $\$ 1335$ (1970)). Its power to do so without limitation has been questioned, see Abraham, Constitutional Limitations upon the Territorial Reach of Federal Process, 8 VIL.L. L. REv. 520 (1963), but it would, for example, be impossible for the Supreme Court to exercise its original jurisdiction without nationwide process. See Sup. Cr. R. 9(3), 9(7), 33(1). 
overreaching by inferior courts. ${ }^{11}$ But it was also applied in interstate cases as a check on territorial overreaching by state courts, ${ }^{12}$ and it saw duty in both state and federal courts against perceived intrusions by one upon the other's domain. ${ }^{13}$

11. Where a judgment was attacked in the state in which it was rendered the rules applied closely resembled the English doctrine. A judgment of a court of inferior jurisdiction had to show on its face the facts necessary to support the exercise of jurisdiction, and these facts could generally be controverted by extrinsic evidence, including parol cridence. See, e.g., Spoors v. Cocn, 44 Ohio St. 497 (1886); I Smith's Leading Cases, supra note 6 , at 828, 830-32, 843. As in England, a judgment of a domestic court of general jurisdiction "imported absolute verity" and could not be impeached by parol or other extrinsic evidence. E.g., Sheldon's Lessee v. Newton, 3 Ohio St. 494, 498-500 (1854). See 1 Sarith's Leadinc Cases, supra note 6 , at $820,823-24,826-28$. This was true even with respect to recitals of service of process. $I d$. at $841-42$. A person against whom a judgment was obtained without notice was required to look "to his remedy against those by whom the record has been falsified." Id. at 834. See generally A. FreEman, A Treatise on the LAW of JUdGMENTS 107-12, 417-19 (1873). "General jurisdiction" referred to proceedings in the course of the common law or in equity, and when a court with such jurisdiction exercised statutory authority which did not fall into one of those two categories, its judgments were subject to the same scrutiny as those of courts of inferior jurisdiction. E.g., Williamson v. Berry, 49 U.S. (8 How.) 495, 536-40 (1850); Gunn v. Howell, 27 Ala. 683 (1855); Whitten v. Coit, 153 Colo. 157, 174-75, 385 P.2d 131, 140-41 (1963). See 1 Smith's Leading Cases, supra note 6, at 832-33; A. Freeman, supra at 94-96 (recognizing rule but questioning its wisdom).

12. E.g., Pennoyer v. Neff, 95 U.S. 714 (1877). Before Pennoyer, territorial sovereignty questions generally arose in cases where full faith and credit was demanded in the courts of one state for a judgment of the courts of another. E.g., D'Arcy v. Ketchum, 52 U.S. (11 How.) 165, 175-76 (1850); see Pennoyer v. Neff, 95 U.S. 714, 729-33 (1877). D'Arcy cites no authority for its holding, but a good development of the interaction between territorial sovereignty notions and the full faith and credit clause appears in the contemporary case of Moulin $\checkmark$. Trenton Mut. Life \& Fire Ins. Co., 24 N.J.L. 222, 235-45 (Sup. Ct. 1853) (opinion of Haines, J.) (following $D^{\prime} A r c y$ ); accord, id. at 230-35 (opinion of Elmer, J.).

In full faith and credit cases the jurisdiction of the rendering court was frequently open to extrinsic disproof (including parol evidence), see A. FreEMAx, supra note 11, at 466.67, which was generally not the practice when domestic judgments were called into question, see note 11 supra. Allowing extrinsic disproof in full faith and credit cases was sanctioned by the Supreme Court in Thompson v. Whitman, 85 U.S. (18 Wall.) 457, 463-68 (1873) (citing earlier dicta). This difference between rules applied to domestic and forcign judgments illustrates the concern of the uineteenth-century roidness cases with overreaching by courts of other sovereignties.

13. E.g., Lessee of Hickey v. Stewart, 44 U.S. (3 How.) 750 (1845) (Mississippi court without jurisdiction to settle title to certain lands ceded by Georgia, where Act accepting cession prescribed different procedure); Slocum v. Wheeler, 1 Conn. 429 (1816) (admiralty decree void where prize captured on land and condemned in wrong district); Taylor v. Carryl, $24 \mathrm{~Pa}$. 259 (1855) (common law foreign attachment of ressel not defeated by subsequent maritime lien in rem; replevin granted buycr at state sheriff's sale against buyer at federal marshal's sale), aff'd, 61 U.S. (20 How.) 583 (1857); Nulton v. Isaacs, $7 \mathrm{~V}$ V. (30 Gratt.) 726, 739.42 (1878) (order of United States Circuit Court, compelling payment, void as judgment). The Supreme Court affirmance in Taylor was by a five-tofour vote. Chief Justice Taney, joined by Justices Wayne, Grier, and Clifford, dissented on the ground that the state attachment reached only the defendant's interest in the vessel, not the vessel itself, and that the marshal's sale therefore passed clear title to the vessel. 61 U.S. (20 How.) at 600-03. He did not, however, dispute that a federal judgment could be void if the federal court were exercising common law powers and attempted to pass title to a res under control of a state court. See id. at 606-09. 
The dimension added by the structure of the American polity was firmly grounded in perceptions of the limited nature of government. In Justice Story's words, "no sovereignty can extend its process beyond its territorial limits, to subject either persons or property to its judicial decisions. Every exertion of authority beyond this limit is a mere nullity, and incapable of binding such persons or property in any other tribunals." 14 State courts might be bound by full faith and credit to respect foreign judgments, but they were entitled to ascertain that their own sovereign prerogatives were not being infringed upon and that their citizens were not being subjected improperly to the dominion of a foreign state. This conception of judicial process is epitomized by Pennoyer v. Neff, ${ }^{15}$ which wrote Justice Story's views on territorial sovereignty into the due process clause of the Fourteenth Amendment. ${ }^{16}$

The cases holding judgments void for reasons other than territorial overreaching lacked a unifying theme. Nevertheless, in such diverse areas as admiralty ${ }^{17}$ and estate contests ${ }^{18}$ they too spoke in terms of power. Some cases, like the English cases before them, ${ }^{19}$ leave the distinct impression that the court was reaching for a jurisdictional issue

14. Picquet v. Swan, 19 F. Cas. 609, 612 (C.C.D. Mass. 1828) (No. 11,134) (Story; Circuit Justice). Thus, originally, personal appearance could be compelled and a party bound to judgment only by arrest of the body. Id. at 613; see Hazard, A Gencral Theory of State-Courl Jurisdiction, 1965 Sup. Cr. Rev. 241, 248 n.19. Within its own borders a state might create whatever substitutes for arrest it decmed sufficient, but when it tried to export its judgments, courts of other states required that the record show service of process within the state or voluntary appearance-actions that clearly showed that the state could have arrested the party sought to be bound, or that he had waived "arrest." E.g., Cooper v. Reynolds, 77 U.S. (10 Wall.) 308, $316-19$ (1870); D'Arcy v. Ketchum, 52 U.S. (11 How.) 165 (1850); Boswell's Lessec v. Otis, 50 U.S. (9 How.) $336,348-49$ (1850). Absent such a showing the decree would be "utterly void." Picquet v. Swan, 19 F. Cas. 609, 612 (C.C.D. Mass. 1828) (No. 11,134) (Story, Circuit Justice).

15. 95 U.S. $714(187 \%)$.

16. Id. at 721-27, 733; see Hazard, supra note 14, at 262-72. Justice Story vicwed the necessary nexus between territorial sovereignty and judicial jurisdiction as a principle "recognized at the common law," but having, "to a certain extent at least, a foundation also in universal jurisprudence." picquet v. Swan, 19 F. Cas. 609, 612 (C.C.D. Mass. 1828) (No. 11,134) (Story, Circuit Justice). His interpretation has been challenged as being an incorrect restatement of the law as it then stood. See Hazard, supra note 14 , at 261. There is, however, no doubt that it did become the law. Pennoyer v. Neff, 95 U.S. 714, 722-24 (1877); see Hazard, supra note 14, at 262.

17. E.g., Town of Pelham v. The Schooner B.F. Woolsey, 3 F. 457 (S.D.N.Y.), aff'd sub nom. Terrell v. The Schooner B.F. Woolsey, 4 F. 552 (C.C.S.D.N.Y. 1880) (prior state judgment void as within exclusive federal admiralty jurisdiction); Slocum v. Whecler, 1 Conn. 429 (1816) (federal judgment in prize case void because prizc captured on land and condemned in wrong district).

18. Elliott v. Lessee of Peirsol, 26 U.S. (1 Pet.) 328 (1828) (failure to follow precise statutory form for conveyance by feme covert voids judgment).

19. See pp. 165-66 \& notes 5-8 supra. 
to enable it to avoid the effects of an inconvenient prior judgment. ${ }^{20}$

Alongside the voidness doctrine was a line of cases that represented attempts to limit the scope of the doctrine. These decisions were descendants of the presumption of regularity due judgments of the royal courts of superior jurisdiction. ${ }^{21}$ In the United States that presumption developed into the notion that some issues, though cast in terms of power, were not "strictly jurisdictional," but merely "quasi jurisdictional." 22 These issues were said to involve "preliminary fact [s] necessary to be proven to authorize the court to act"; ${ }^{23}$ where they were involved a court could be said to have the power to determine the question of its power. Its determination, if wrong, was "mere error" and did not result in a void judgment. ${ }^{24}$

In the federal courts, the most important example of a quasi-jurisdictional issue was diversity of citizenship as a basis for federal jurisdiction. Although the jurisdiction of the federal courts is limited to the nine categories enumerated in article III of the Constitution, the Supreme Court early held that a judgment in a diversity action need not affirmatively show the presence of diversity in order to be valid. ${ }^{25}$ This was merely a holding that the federal courts, although "limited," were not "inferior," and that, consequently, their judgments were en-

20. See, e.g., Nulton v. Isaacs, 71 Va. (30 Gratt.) $726,738-43$ (I878) (in suit to sct aside allegedly fraudulent conveyances, prior federal judgments held ineffective as liens because of asserted jurisdictional defect, but partial relief granted on other grounds). But see, e.g., Town of Pelham v. The Schooner B.F. Woolsey, 3 F. 457 (S.D.N.Y.), aff'd sub nom. Terrell v. The Schooner B.F. Woolscy, 4 F. 552 (C.C.S.D.N.Y. 1880) (arriving at essentially same result on merits as prior judgment found to be void). Jurisdiction was to be determined by "the face of the record." See note 11 supra. Courts eager to avoid a prior judgment have therefore taken expansive views of what constitutes a facial defect. See, e.g., Nulton v. Isaacs, $i l$ Va. (30 Gratt.) 726 , $739-42$ (1878). For an egregious modern example, see Farley v. Farley, 227 Cal. App. 2d I, 38 Cal. Rptr. 357 (1964), where a portion of a Utah divorce decree was held void as beyond the statutory powers of a Utah divorce court. The Utah court, which had general equity powers, had imposed a trust on some land owned by the husband, with the wife as trustec and the couple's children as both beneficiaries and, upon achieving majority, remaindermen. The California court found Utah law to be silent on the powers of divorce courts to create such remainder interests in favor of adult children and thus applied California law to hold the Utah decree void on its face.

2I. See In re Sawyer, 124 U.S. 200, 221 (1888) (citing both Prigg v. Adams, Carthew 274, 90 Eng. Rep. 762 (K.B. 1694) (digested at 2 Salk. 674, 91 Eng. Rep. 573) (discussed in note 8 supra), and Des Moines Navigation \& R.R. v. Iowa Homestead Co., 123 U.S. 552 (1887) (discussed at p. 170 infra; see also note 151 infra), for proposition that errors as to certain facts "which might or might not support the jurisdiction" do not render decree void).

22. Noble v. Union River Logging R.R., 147 U.S. 165, 173 (I893). For similar language in a state case, see Abraham v. Homer, 102 Okla. 12, 14-15, 226 P. 45, 47-48 (1924).

23. Noble v. Union River Logging R.R., 147 U.S. 165, 174 (1893).

24. E.g., id. at 173-74; Wyatt's Adm'r v. Steel, 26 Ala. 639, 650 (1855); Bumstead v. Read, 31 Barb. 661, 669-70 (App. Div. 1859); see Kohl v. Hannaford, 5 Ohio Dec. Reprint 306 (Super. Ct. 1875).

25. M'Cormick v. Sullivant, 23 U.S. (10 Wheat.) 192 (1825). 
titled to the presumption of regularity due judgments of superior courts. ${ }^{26}$ Some years later, however, the Court went much further. In Des Moines Navigation \& Railroad $v$. Iowa Homestead Co., ${ }^{27}$ it held that a judgment was immune to attack on grounds of want of diversity even when the defect was shown on the face of the record. ${ }^{28}$ Although the Court mentioned the respect due the "limited but not . . . inferior" "federal courts, ${ }^{29}$ the new rationale was far broader than the earlier one. It was based upon the need for finality and it emphasized the responsibility of litigants to raise jurisdictional issues in the original litigation. ${ }^{30}$

Both the voidness doctrine and the countervailing line of cases involved attacks on judgments at law. In addition, equitable relief from judgments was occasionally available, both in England and the United States. ${ }^{31}$ Since James I settled the conflict between Lord Chief Justice Coke and Lord Chancellor Ellesmere in 1613,32 courts of equity have had the undisputed power to enjoin enforcement of judgments of the law courts, including the superior courts, on a number of grounds. ${ }^{33}$ Even so, the right to equitable relief was not unfettered. Equitable attacks were first and foremost proceedings in equity, and as such were subject to equitable defenses such as unclean hands and laches. ${ }^{34}$

26. Id. at 199-200.

27. 123 U.S. $552(1887)$.

28. Id. at 556-59.

29. Id. at 557-58 (quoting $M^{\prime}$ Cormick) (emphasis omitted).

30. Id. at 558-59. The existence of a federal question has also been held to be quasijurisdictional. Dowell v. Applegate, 152 U.S. 327, 340 (1894).

Among state courts, a typical quasi-jurisdictional issue (although that language was not used) was domicile for probate jurisdiction. See, e.g., Bumstead v. Read, 31 Barb. 661 (App. Div. 1859); A. Freeman, supra note 11, at 442 . For a discussion of probate cases applying a strictly jurisdictional standard, see Jochumsen $v$. Suffolk Savings Bank, 85 Mass. (3 Allen) 87, 89.96 (1861).

31. See A. Freeman, supra note 11, at 409; F. James, supra note 1, at 13-16; First Restatement \$ 112.

32. See F. JAMES, supra note 1 , at 15 . It is worthy of note that The Marshalsea, 10 Co. Rep. 68b, 77 Eng. Rep. 1027 (1613), which established the voidness doctrine in the law courts, see pp. 165-66 supra, was also decided-and by Lord Coke-in 1613.

33. See 2 J. Story, Commentaries on Equity Jurisprudence 165-78 (2d cd. Boston 1839) (1st ed. Boston 1835). These grounds included equitable defenses to the original action, see id. at 170-71, and could generally be asserted either before or after judgment at law. See id. at 173, 178-79. In particular, the equity courts would act to prevent enforcement of judgments procured by fraud. See $i d$. at 172-73; cf. First RestateareNt $\$ \$$ 118, 120-124 (rule as of 1942). The rule that judgments of superior courts imported absolute verity, see note 11 supra, might thus have rested in part on the view that it was not outrageous to deny parties the right to controvert the face of the record at law if they could do so in a suit for equitable relief. See, e.g., Ridgeway v. Bank of Tenn., 30 Tenn. (11 Humph.) 523 (1851); cf. A. Freeman, supra note 11, at 417-19 (equity "peculiarly appropriate" for exposure of want of service). But cf. Walker v. Robbins, 55 U.S. (14 How.) 584 (1852) (dictum) (where false recital not due to plaintiff's fault or fraud, equity will not intervene).

34. See A. Fremman, supra note 11 , at 425-2\%; First Restatement $\$ \$ ~ 127-130$. 
The three doctrinal strands-voidness, jurisdiction to determine jurisdiction, and equity ${ }^{35}$-stood alongside one another for many years, with only the most cursory acknowledgment of each other's existence. Despite attempts of treatise writers to codify and to classify, by 1925 the state of the law of judgments could charitably be described as confused. ${ }^{36}$

The voidness doctrine developed in England to establish the supremacy of the royal courts; it flourished in the United States in the nineteenth century primarily as a means for states to protect their citizens against overreaching by courts of other states. In both countries it functioned to protect the prerogatives of some courts at the expense of others. As Professor Dobbs has noted, however, "almost every reason that history suggests to support the [voidness doctrine] has disappeared." 37 He continued:

Even the problems of our own federal system do not measure up to the heated conflict of the English courts. We need not look to the jurisdictional concept to gain adequate appellate review of cases otherwise barred from revision. A written constitution gives us a basis for insuring reasonable rules of law and procedure wholly independent of the jurisdictional concept. ...

Furthermore, it is apparent today that the problem of our judicial system is the problem of overburden rather than under-work, the problem of finality rather than the problem of injustice. When the no consent rule [i.e., the voidness doctrine] was developing, res judicata was not the significant legal tool that it is today, and the policies of res judicata were not weighed in the balance. ${ }^{3 s}$

\section{B. The Modern Doctrine}

A doctrine whose historical justifications have receded with time is not likely to survive unchanged. The voidness doctrine is no exception. The second quarter of this century saw the beginning of a

35. The importance of the independent equitable attack on a judgment has declined somewhat since the inclusion in 1938 of most of the grounds for such attacks into postjudgment relief by motion. See FED. R. Civ. P. 60(b) (discussed in note 45 infra).

36. The fifth edition of Freeman's Treatise on the Law of Judgments, published in 1925, had grown to three volumes from the original one. All the doctrinal strands appeared, constituting most of Chapters VII and XXI, but it is difficult to abstract from the Trealise any sense that one could determine which strand would be applied in any particular case. For an earlier example of the confusion, see Justice Brown's attempt to distinguish "strictly jurisdictional" questions from "quasi jurisdictional" ones in Noble v. Union River Logging R.R., 147 U.S. 165, 173.74 (1893).

37. Consent, supra note 5 , at 78 .

38. Id. at 78-79. 
procedural revolution in the United States; ${ }^{39}$ that revolution has had a significant impact both on the voidness doctrine and on the broader question of the nature of judicial power. ${ }^{40}$

The revolution was characterized by an emphasis on functional indicia of fairness, both in shaping current litigation and in determining the impact of prior litigation. Thus the Federal Rules of Civil Procedure, adopted in 1938, emphasized a flexible approach to litigation, with notice pleading ${ }^{41}$ complemented by broad discovery ${ }^{42}$ and with liberal joinder of claims ${ }^{43}$ and parties. ${ }^{44}$ The object was to provide as fair and effective a method as possible for the resolution of disputes. ${ }^{45}$ At the same time, the constitutionalization of notice requirements for personal jurisdiction imposed a fairness constraint on the exercise of judicial power: a party who has not had an opportunity to contest a claim against him is not bound by a judgment entered on that claim. ${ }^{46}$ This development of notice as a necessary

39. See, e.g., Degnan, Federalized Res Judicala, 85 Y^LЕ L.J. 741, 741-42 (1976); Vestal, Res Judicata/Preclusion: Expansion, 47 S. CAL. L. REv. 357, 357-59 (1974) [hereinafter cited as Expansion].

40. See pp. 174-81 infra.

41. FED. R. Crv. P. 8.

42. FED. R. Civ. P. 26(b)(1). See generally FED. R. Civ. P. 26-3\%.

43. FED. R. Crv. P. 13, 18.

44. FED. R. Civ. P. 14, 19-21, 24.

45. Fed. R. Civ. P. 1. See also Fed. R. Civ. P. 15(b) (amendment of pleadings to conform to evidence), 16 (pre-trial conference). For a general discussion of the differences between the Rules and prior practice, see D. LourselL \& G. HAZARD, supra note 1, at 35-38.

The accommodation the Rules found between finality and justice is found in Rules 55 (c) (setting aside default) and 60 (relief from judgment). As originally adopted in 1938, Rule 60 did not mention voidness, but the 1946 revision added as a ground for relief that "the judgment is void." FED. R. CIV. P. 60(b)(4). The addition of this ground was not adverted to in the Advisory Committee Notes except insofar as voidncss was encompassed by the common law post-judgment writs of coram nobis, coram vobis, and audita querela, which were subsumed by the rule. See Notes of Advisory Committee on 1946 Amendment to Rules, reprinted in 28 U.S.C. app. (1970) (following Rule 60). The 1946 Amendment was a revision by professor Moore of the original proposal of the Advisory Committee. See Moore \& Rogers, Federal Relief from Civil Judgments, 55 YaLe L.J. 623, 690-93 \& n.272 (1946) (article cited frequently in Advisory Committee Notes). Professor Moore has stated that the addition of $60(b)(4)$ was agreed to without difficulty and was regarded simply as a housekeeping measurc. Telephone Conversation with J.W. Moore, April 12, 1977 (notes on file with l'ale Law Journal). Thus the entire "legislative history" of Rule $60(\mathrm{~b})(4)$ is the statement that "the rule should recognize that a cont can purge its records of void judgments." Moore \& Rogers, supra, at 692.

46. Walker v. City of Hutchinson, 352 U.S. 112 (1956) (due process forbids notice of condemnation proceedings solely by publication where condemuce known); Mullane $v$. Central Hanover Bank \& Trust Co., 339 U.S. 306, 314-15, 318-19 (1950) (in action to settle trustce's accounts, due process requires notice "reasonably calculated" to inform all reasonably identifiable beneficiaries); Wuchter v. Pizzutti, 276 U.S. 13 (1928) (state may declare use of highways equivalent to appointment of state official as "agcnt" to receive service of process, but provision for making actual notice to defendant "reasonably probable" nevertheless required in order to bind him). See First Restatemest $\S 6$; Hazard, supra note 14 , at $275-7 \pi$. 
condition for the exercise of judicial porver was accompanied by the expansion of state "longarm" jurisdiction, beginning in International Shoe Co. $v$. Washington, ${ }^{47}$ which went in the direction of making notice a sufficient condition as well. The determinant of state judicial power began to shift from the territorial sovereignty of Pennoyer to a pragmatic, fairness-oriented test of sufficient contacts between party and forum to justify exercise of judicial power. ${ }^{48}$

The increased emphasis on fairness in the process of litigation made possible an expansion of the binding effect of judgments. Having been provided a fair opportunity to settle an entire dispute in one action, a party might reasonably be precluded from reopening the matter. In part, the influence of liberal joinder rules in expanding the notion of "cause of action" brought a parallel expansion in those rules of res judicata/preclusion ${ }^{49}$ that are designed to prevent more than one litigation of a single cause of action. ${ }^{50}$ There were other, less automatic developments, however, notably Justice Traynor's decision in Bernhard v. Bank of America National Savings \& Trust Association. ${ }^{51}$

47. 326 U.S. 310 (1945). But see Hanson v. Denckla, 357 U.S. 235 (1958). In Hanson the Court appeared to return at least part way to Pennoyer's emphasis on territorial sovereignty. See $i d$. at 249-52. The case has been sharply criticized, see Hazard, supra note 14, at 243-45, but it has also been followed, e.g., Bernardi Bros., Inc. v. Pride Mfg., Inc., 427 F.2d 297 (3d Cir. 1970). See generally R. Cramton, D. Currie \& H. KaY, CoNflict of LAw' 526-28 (2d ed. 1975). The viability of Hanson after the recent decision in Shaffer v, Heitner, $97 \mathrm{~S}$. Ct. 2569 (1977) (discussed in note 48 infra), is unclear. See id. at 2580 n.20, 2584 n.38, 2586-87 (discussing Hanson in varying terms). For a discussion of the relation between personal jurisdiction and due process, see note 92 infra.

48. See Hazard, supra note 14, at 281-88.

The shift away from Pennoyer appears to have been completed by the recent decision in Shaffer v. Heitner, $97 \mathrm{~S}$. C.t. 2569 (1977). At issue in Shaffer was the validity of a statute permitting Delavare courts to obtain jurisdiction over a non-resident defendant by "sequestering" any of defendant's property located in Delawarc. Id. at 2572. After" reviewing the development of state jurisdiction from Pennoyer to International Shoe, id. at $2576-81$, the Court concluded:

The fiction that an assertion of jurisdiction over property is anything but an assertion of jurisdiction over the owner of the property supports an ancient form without substantial modern justification. Its continued acceptance would serve only to allow state court jurisdiction that is fundamentally unfair to the defendant.

We therefore conclude that all assertions of state court jurisdiction must be evaluated according to the standards set forth in Inlernational Shoe and its progeny. Id. at 2584-85 (footnote omitted). Pennoyer and Harris v. Balk, 198 U.S. 215 (1905), werc overruled "[t]o the extent that [they] are inconsistent with this standard." Id. at 2585 n.39. The Court then found that, under the test of Hanson v. Denckla, 357 U.S. 235 (1958) (discussed in note 47 supra), the defendants did not have sufficient contacts with Delaware to permit Delaware to excrcise jurisdiction orer them. 97 S. Ct. at $2585-87$.

49. For a development of the theory of res judicata/preclusion, see pp. 184-88 \& notes 99-120 infra.

50. See D. Louisell \& G. HAZARD, supra note 1, at 619-22.

51. I9 Cal. 2d 807, 122 P.2d 892 (1942) (Traynor, J.). In what has been called "a triumph of judicial statesmanship," B. Currie, Mutuality of Collateral Estoppel: Limits of the Bernhard Doctrine, 9 Srax. L. Rev. 281, 285 (1957), Justice Traynor abolished the "mutuality rule" of collateral estoppel-the doctrine that a determination of an issue, 
The impact of the procedural revolution on the voidness doctrine was not long in making itself felt. The Supreme Court, ${ }^{52}$ in a series of decisions between 1931 and 1963-with the main decisions coming in a sixteen-month period between 1938 and 1940-fundamentally altered the relationship between finality and judicial power in the United States. First, in Baldwin v. Iowa State Traveling Men's Association, ${ }^{53}$ the Court held that a party who had appeared in the prior action to contest the forum's jurisdiction over his person was bound by an adverse determination and could not subsequently attack the judgment on jurisdictional grounds. ${ }^{5 *}$ Then, in 1938, in Stoll $v$. Gottlieb, ${ }^{\bar{a}}$ the

in litigation between $A$ and $B$, adversely to $A$, was generally not binding on $A$ in a subsequent litigation between $A$ and $C$. See First Restatemest $\$$ 93(b). Justice Traynor replaced the mutuality rule with a three-step test for determining whether $A$ would be bound in the action against $C$ : "Was the issue decided in the prior adjudication identical with the one presented in the action in question? Was there a final judgment on the merits? Was the party against whom the plea is asserted a party or in privity with a party to the prior adjudication?" 19 Cal. $2 \mathrm{~d}$ at $813,122 \mathrm{P} .2 \mathrm{~d}$ at 895 . In so doing he made general the prior exceptions to mutuality that had rested "on the ground that it would be unjust to permit one who has had his day in court to reopen identical issues by merely switching adversaries." Id.

52. The Court's decisions are controlling precedent only where the federal law of judgments is involved, but its decisions have nevertheless had great impact. First, of course, the Court's prestige adds weight to its decisions when, acting as a common law court, it lays out the federal common law of judgments. More important, however, is that many cases raise federal questions. The scope of a federal judgment is a federal question. Stoll v. Gottlieb, 305 U.S. 165, 170-71 (1938); Embry v. Palmer, 107 U.S. 3 (1882) (construing predecessor to 28 U.S.C. $\$ 1738$ (1970) (full faith and credit statute)); see Degnan, supra note 39 , at $746-49$. So, too, is the effect of a judgment of a court of one state in the courts of another. Magnolia Petroleum Co. v. Hunt, 320 U.S. 430, 439 (1943). In full faith and credit cases the scope of the judgment is controlled by the law of the rendering state, Johnson v. Muelberger, 340 U.S. 581, 587 (1951), but the determination of that law raises a federal question, id. at 585 .

53. 283 U.S. 522 (1931).

54. But cf. In re Stern, 235 F. Supp. 680, 682-83 (S.D.N.X. 1964) (Weinfeld, J.) (Baldwin not applicable where appeal from jurisdictional ruling dismissed for failure to post bond).

55. 305 U.S. 165 (1938). Accord, Jackson v. Irving Trust Co., 311 U.S. 494 (1941); Davis v. Davis, 305 U.S. 32 (1938).

In Stoll, Gottlieb was a bondholder of a corporation in reorganization under $\$ 77 \mathrm{~B}$ of the Bankruptcy Act, Act of June 7, 1934, ch. 424, 48 Stat. 912 (superseded by Chapter $\mathrm{X}$ of the Bankruptcy Act, 11 U.S.C. $\$ \$ 501-676$ (1970)). Stoll had guaranteed some of the corporation's bonds, including those held by Gottlieb. At a creditors' meeting (of which Gottlieb had notice but which he did not attend) a reorganization plan was devised that included a provision for extinguishing the Stoll guarantees, and the plan was approved by the supervising district court. Gottlieb's petition to have the plan set aside, on the ground that extinguishing the guarantees was beyond the power of the bankruptcy court, was denied, and Gottlieb did not appeal. Instead, he sued Stoll on the guarantees in the Illinois courts, and judgment in favor of Gottlieb was upheld by the Illinois Supreme Court on the ground that the bankruptcy court had not had the power to extinguish the guarantees. Gottlieb v. Crowe, 368 Ill. 88,12 N.E.2d 881 (1937), rev'd sub nom. Stoll v. Gottlieb, 305 U.S. 165 (1938). The United States Supreme Court, in reversing, held that the bankruptcy court's unappealed determination of the extent of its power was res judicata berause the issue had been fully litigated in the bankruptcy court. 305 U.S. at 172 . 
Court extended the Baldwin doctrine to cover at least some issues of subject-matter jurisdiction. In short order-in Treinies $v$. Sunshine Mining Co..$^{56}$ and Chicot County Drainage District v. Baxter State Bank ${ }^{57}$-Stoll was extended to establish that most judgments are not subject to attack for want of subject-matter jurisdiction. ${ }^{58}$ The link between jurisdiction and power was crumbling. Stoll, Treinies, and Chicot each rejected a substantial voidness-based attack with sweeping fairness/finality language; together, these cases demolished, with one glaring exception, the voidness doctrine as it had developed in the nineteenth century. In essence, the inquiry was to be shifted from the power vel non of the rendering court to the conduct of the parties before it.

Despite this fundamental shift in emphasis the voidness doctrine

56. 308 U.S. 66 (1939). Treinies was an interpleader action instituted by Sunshine after Washington and Idaho courts had entered conflicting judgments concerning title to a block of Sunshine stock. The Washington court's judgment came first; it awarded the stock to one of the claimants after its jurisdiction had been tested in prohibition proceedings in the Washington Supreme Court. 308 U.S. at 69-70. The Idaho court nevertheless concluded that the Washington court did not have jurisdiction and found in favor of the other claimant. Mason v. Pelkes, 57 Idaho 10, 59 P.2d 1087 (1936), cert. denied, 299 U.S. 615 (1937). When the conflicting judgments reached the United States Supreme Court in the interpleader case, the Court held that the Idaho judgment must control. The asserted ground for that judgment's invalidity-the exclusive jurisdiction of the Washington court-had been litigated in the Idaho case and was therefore res judicata. 308 U.S. at 74-78. In concluding a litigation that had involved the Idaho and Washington-and, finally, the federal-courts, the Court said: "One trial of an issue is cnough. 'The principles of res judicala apply to questions of jurisdiction as well as to other issues,' as well to jurisdiction of the subject matter as of the parties." 308 U.S. at 78 (footnotes omitted).

57. 308 U.S. 371 (1940). The Drainage District had been reorganized under the first Municipal Bankruptcy Act, ch. 345,48 Stat. 798 (1934), which was subsequently held to be unconstitutional in Ashton v. Cameron County Water Improvement Dist. No. One, 298 U.S. 513 (1936). The bank had had notice of the reorganization proceedings but had not participated in them. It did not tender its bonds pursuant to the plan, choosing instead (after Ashton) to sue for payment. The Supreme Court held that the judgment confirming the plan could not be attacked collaterally: although jurisdiction had been purely statutory and the jurisdictional statute may have been unconstitutional, even an unconstitutional statute may generate reliance interests worthy of judicial protection. 308 U.S. at 374 . In addition, the Court emphasized that the bondholders had had an opportunity to raise the jurisdictional question in the original action and were not "privileged to remain quiet and raise it in a subsequent suit." Id. at 378. At the heart of the opinion was the assertion that

[w] hatever the contention as to jurisdiction may be, whether it is that the boundaries of a valid statute have been transgressed, or that the statute itself is invalid, the question of jurisdiction is still one for judicial determination. . . There can be no doubt that if the question of the constitutionality of the statute had actually been raised and decided in the District Court ... ., that determination would have been final save as it was open to direct review upon appeal. [citing Stoll]. Id. at 377-78 (footnote omitted).

58. See generally Boskey \& Braucher, Jurisdiction and Collateral Attack: October Term, 1939, 40 Colum. L. Rev. 1006 (1940); Note. Res Judicala and Jurisdiction: The Boolstrap Doclrine, 53 HaRv. L. REv. 652 (1940). 
did not entirely disappear, for the Court twice invoked it to preserve important national policies. In Kalb v. Feuerstein ${ }^{59}$ the Kalbs sued to cancel a sheriff's deed issued at the sale following foreclosure of the mortgage on their farm. ${ }^{0}$ The sale was confirmed while the Kalbs' petition for composition and extension of time to pay their debts, filed under the second Frazier-Lemke Act, ${ }^{01}$ was pending in federal district court. The Act provided that the "filing of a petition ... shall immediately subject the farmer and all his property, wherever located, ... to the exclusive jurisdiction of the [federal district] court." 62 Further, the Act explicitly prohibited confirmation of foreclosure sales during the pendency of a petition. ${ }^{63}$ The Kalbs asserted that the jurisdiction of the state court had been ousted by the pendency of the petition, so that the confirmation decree was void. The Wisconsin courts held the Kalbs to be precluded from attacking the decree because they had not sought a stay of the foreclosure proceedings from the district court, nor had they raised the pendency of the petition in the foreclosure court. ${ }^{64}$

The Supreme Court reversed. It held that the Frazier-Lemke Act deprived state courts of "the power and jurisdiction to continue or maintain" foreclosure proceedings "in any manner" after a petition

59. 308 U.S. 433 (1940).

60. The Kalbs also sued the sheriff for conspiracy to deprive them of possession, for false imprisonment, and for assault and battery. They based their claims on a lessthan-peaceful execution of a writ of assistance sued out to put the Feuersteins in possession. See id. at $436-37$. The stit against the sheriff is reminiscent of English roidness actions, discussed in note 7 supra.

61. Act of Aug. 28, 1935, ch. 792, 49 Stat. 942; see 11 U.S.C. $\$ 203$ note (1970) (explanation of Act's current status). The judgment of foreclosure was entered April 21, 1933 , but under Wisconsin law no sale could be made or advertised for one year thereafter. More than a year later, on October 2, 1934, the Kalbs filed their petition in the federal court, pursuant to the first Frazier-Lemke Act, ch. 869, 48 Stat. 1289 (1934). That Act was held unconstitutional in Louisville Joint Stock Land Bank v. Radford, 295 U.S. 555 (1935) (provision in Act for mandatory sale of farm by mortgagee back to mortgagor at price less than secured debt constitutes uncompensated taking in violation of Fifth Amendment), and the district court thereupon dismissed the petition. When Congress amended the Act to remove the offending language, the district court vacated the order of dismissal and reinstated the petition. Between the dismissal and the reinstatement, however, the farm was sold at a sheriff's sale, although a confirmation hearing (necessary to pass title) was not held until after the petition was reinstated. Brief of the Appellants in Nos. $120 \& 121$, at 4-5; Brief of the Respondents in No. 121 at $3-4$.

62. Second Frazier-Lemke Act, ch. 792, $\$ 4,49$ Stat. 942 (1935).

63. Id.

64. Kalb v. Luce, 228 Wis. 519, 523-24, 279 N.W. 687 , on rehearing, 280 N.W. 725, 726, appeal dismissed for want of final judgment, 305 U.S. 566 (1938), adhered to on remand, 231 Wis. 186, 285 N.W. 431 (1939), rev'd sub nom. Kalb v. Feuerstein, 308 U.S. 433 (1940). The Kalbs had served a copy of the reinstatement order on the state judge three days before the confirmation hearing and had filed another copy in the state court on the day originally set for the hearing. Bricf of the Appellants in Nos. 120 \& 121 at 5, Kalb v. Feuerstein, 308 U.S. 433 (1940). See pp. 209.10 \& note 209 infra. 
was filed, ${ }^{65}$ and it stressed that normal res judicata rules, such as those applied in Stoll and Chicot, "are not applicable where the plenary power of Congress over bankruptcy has been exercised as in this Act." 60

In Kalb the Court purported to rely on a statute. In United States v. United States Fidelity is Guaranty Co. ${ }^{67}$ however, the Court applied the voidness doctrine because of the absence of a statute. Two Indian Nations had leased coal lands to a company that subsequently went into receivership; Fidelity was the surety for royalties due under the lease. ${ }^{68}$ The Government, on behalf of the Indians, filed a claim for the royalties in bankruptcy proceedings, but the receiver denied liability and counterclaimed for certain credits; the bankruptcy court found a balance due the company. ${ }^{69}$ The Government did not appeal but, prior to entry of the final decree, sued on the royalty bond in another district. Fidelity pleaded the final decree of the bankruptcy court as a bar to this second suit, and the receiver intervened as a defendant and counterclaimed for recognition of his judgment. The Government responded that the bankruptcy court had been without jurisdiction to do more than allow a setoff, since absent a congressional waiver both the United States and its Indian wards were protected against affirmative claims by sovereign immunity. ${ }^{70}$ The Supreme Court held that the failure to object to the award in the bankruptcy proceedings was not fatal, since

the suability of the United States and the Indian Nations, whether directly or by cross-action, depends upon affirmative statutory authority. . . . Absent that consent, the attempted exercise of judicial power is void. The failure of officials to seek review cannot give force to this exercise of judicial power. Public policy forbids the suit unless consent is given, as clearly as public policy makes jurisdiction exclusive by declaration of the legislative body [citing Kalb]. Chicot County Drainage District v. Baxter State Bank is inapplicable where the issue is the waiver of immunity. ${ }^{71}$

The modern voidness doctrine, as framed by the Court in the five cases discussed above, retains, but in a sharply limited way, the concept

65. 308 U.S. at 440 .

66. Id. at 444 .

67. 309 U.S. $506(1940)$.

68. Brief for the United States at 3-4, United States v. United States Fidelity \& Guar. Co., 309 U.S. 506 (1940).

69. Id. at 5-6.

70. Id. at 6-7. For a discussion of the precise contours of the claim of immunity, including an argument that there had in fact been a waiver, see note 246 infra.

71. 309 U.S. at 514 (footnotes omitted). 
of excess of judicial power that was the foundation of the historical doctrine. Stoll, Treinies, and Chicot indicate that if the proceedings in the original action comported with minimal due process-the right to a hearing, upon fair notice, before an impartial tribunal-then most questions of judicial power become less important than preserving the finality of judgments. Nevertheless, in Kalb and Fidelity the Court held that there are some issues that simply are more important than finality. Those two cases, moreover, cannot be viewed as aberrations, for they were unanimous decisions by essentially the same Court that unanimously decided Stoll, Treinies, and Chicot. ${ }^{72}$ Indeed, Kalb and Chicot were handed down on the same day. The five cases must be viewed as somehow consistent in the Court's mind.

The first major attempt to rationalize these cases was the Restatement of Judgments, ${ }^{73}$ which appeared two years after Fidelity. The Restatement holds that the judgment of a court having jurisdiction over the parties to an action should generally not be vulnerable to attack for want of subject-matter jurisdiction. ${ }^{74}$ But the Restatement would permit attacks if "the policy underlying the doctrine of res judicata is outweighed by the policy against permitting the court to act beyond its jurisdiction." ${ }^{75}$ This formulation has been criticized, ${ }^{78}$

72. The Stoll Court consisted of Chief Justice Hughes and Justices McReynolds, Brandeis, Butler, Stone, Roberts, Black, and Reed, with one seat vacant. By the time Fidelity was decided, 16 months after Stoll, Justices Frankfurter, Douglas, and Murphy had come on the Court, replacing Justices Brandeis and Butler and filling the vacant seat. Stoll, Treinies, and Fidelity were written by Justice Reed, Kalb by Justice Black, and Chicot by Chief Justice Hughes. Justice Butler did not take part in deciding Treinies; Justice McReynolds did not take part in Fidelity and concurred without opinion in Stoll.

73. First Restatement $\$ 10$. See also id. $\$ \S 4-8$ (requisites of valid judgment).

74. Section 9 of the Restatement codifies the rule of Baldwin v. Iowa Statc Traveling Men's Ass'n, 283 U.S. 522 (1931), concerning personal jurisdiction:

Where a defendant appears in an action to object that the court has no jurisdiction over him and the court overrules the objection and judgment is rendered against him, the parties are precluded from collaterally attacking the judgment on the ground that the court had no jurisdiction over the defendant.

75. Id. $\$ 10(1)$. Section 10(2) mentions five factors "appropriate to be considered in determining that collateral attack should be permitted":

a) the lack of jurisdiction over the subject matter was clear;

b) the determination as to jurisdiction depended upon a question of law rather

than of fact;

c) the court was one of limited and not of general jurisdiction;

d) the question of jurisdiction was not actually litigated;

e) the policy against the court's acting beyond its jurisdiction is strong.

Section 10 has been characterized as "a correct statement of the law as the Supreme Court has developed it." Duke v. Durfee, 308 F.2d 209, 217-18 (8th Cir. 1962) (BlackmuI, J.), rev'd, 375 U.S. 106 (1963). The Supreme Court disagreed with the weight Judge Blackmun assigned to the policies at stake, but it did not disagree with the balancing test itself. See p. 179 \& note 7 infra.

76. See 1B Moore's Federal Practice ff 0.405[4], at 648-49 \& n.41 (2d cd. 1974); Green, Res Judicata and Its Applicability to Judgments, 28 MiNN. L. Rev. 77 (1944). 


\section{but the Supreme Court has indicated its approval of the balancing test. 77}

The most recent scholarly attempt at synthesis, ${ }^{78}$ as well as the most comprehensive, is the work of Professor Dobbs. In a series of four articles in the mid-1960s, ${ }^{79}$ Dobbs developed an elaborate analysis of the "bootstrap principle," the process by which otherwise void judg-

Professor Moore takes a position similar to the one taken in this Note by arguing that a policy "which treats a judicial determination as waste paper [can seldom] outweigh society's interest in having the determination of its courts respected, especially when they are courts of competent jurisdiction." $1 \mathrm{~B}$ Moore's Federal Practice if 0.405 [4], at 649 (2d ed. 1974). But his attack on the Restatement is flawed by his assertion that public policy does have a role to play in res judicata determinations, $i d$. at 650 . Compare id, and id. If $0.405[11]$, at 786 with FiRsT REsTATEMENT $\$ 10$, comment b, at 62. See also Dobbs, The Validation of Void Judgments: The Bootstrap Principle (pt. 2), 53 VA. L. REv. 124I, 1246.47, 1249-50 (1967) (criticizing Moore's analysis of Kalb and Fidelily).

77. Durfee v. Duke, 375 U.S. 106, 114 n.12 (1963) (quoting Restatement of ConFLICT - OF LAws $\$ 451$ (2) (Supp. 1948), which is identical to $\S 10$ of the Restatement of Judgments).

Durfee is the most recent Supreme Court decision in this area, and it appears to put to rest any doubts as to whether state courts may attack each other's judgments on traditional territorial sovereignty/subject-matter jurisdiction grounds. See Currie, Full Faith and Credit, Chiefly to Judgments: A Role for Congress, 1964 Sup. CT. Rev. 89, 103-09. At issue was title to a tract of land that had once been an island in the Missouri River, whose path formed the boundary between the states of Nebraska and Missouri. Durfee claimed under a Nebraska sheriff's deed and Duke under a Missouri swamp land patent; the only question was whether the land was in Missouri or Nebraska. That question turned on the nature of a shift in the river's course; it was litigated in the Nebraska courts in a quiet-title action brought by Durfee, and the Nebraska Supreme Court erentually found that the land was in Nebraska. Durfee v. Keiffer, 168 Neb. 272, 95 N.T.2d 618 (1959). When Duke then sued in Missouri to quiet title, Durfee removed to federal district court on diversity grounds and pleaded the Nebraska decree as a bar. The district court disagreed with the Nebraska court's assessment of the shift in the river's course. But it agreed with Durfee that the issue was precluded by the Nebraska judgment and therefore dismissed the action. The Eighth Circuit, in reversing, applied the Restatement's balancing test, see note 75 supra, and held that Missouri's interest in controlling land within its borders overrode preclusion policies. Duke v. Durfee, 308 F.2d 209 (8th Cir. 1962) (opinion of Blackmun, J.), rev'd, 375 U.S. 106 (1963). In unanimously reversing the Eighth Circuit, the Supreme Court held that Duke had had a full and fair opportunity to litigate the jurisdictional question in the Nebraska action and thus could not raise that question to attack the Nebraska judgment. 375 U.S. at 111.

78. For others, and for discussions of related matters, see Z. Chafee, Some Problems of EQuiTY 296-380 (1950) (decrees of courts vested with general equity powers should not be subject to attack for "want of equity jurisdiction"); Boskey \& Braucher, supra note 58; Cox, The Void Order and the Duty to Obey, $16 \mathrm{U}$. CHr. L. REv. 86, 110-11 (1948) (subject-matter jurisdiction of court entering interlocutory order inappropriate criterion for determining whether violation of order punishable by contempt); Currie, supra note 77; Gavit, Jurisdiction of the Subject Matter and Res Judicata, 80 U. PA. L. REv. 386 (1932) (court without jurisdiction should be treated as common law arbitrator and its judgments as awards); Note, supra note 58. See also note 76 supra (citing sources).

79. Consent, supra note 5; Dobbs, Trial Court Error as an Excess of Jurisdiction, 43 TEx. L. REv. 854 (1965) [hereinafter cited as Error]; Dobbs, The Validation of Void Judgments: The Bootstrap Principle (pts. 1 \& 2), 53 VA. L. Rev. 1003, 1241 (1967) [hereinafter cited as Bootstrap]; Dobbs, Beyond Bootstrap: Foreclosing the Issue of Subject-Maller Jurisdiction Before Final Judgment, 51 MIN. L. REv. 491 (1967) [hereinafter cited as Beyond Bootstrap]. 
ments are "validated." 80 He proposed a two-step inquiry: first, whether the will of the sovereign, as expressed in constitutional provisions and legislative enactments, supports application of bootstrap to the judgment under consideration; then, whether bootstrap, though permissible, should for reasons of public policy not be applied. ${ }^{81}$ His first step is in a sense quite classical, for it focuses directly on the power of the rendering court. It is not immediately concerned, however, with that court's power vel non over the particular case before it, but rather with its power to determine whether it had such power $-i t s$ jurisdiction to determine its jurisdiction. The existence of this power is to be determined a priori, without regard to the conduct of the litigants in the original action, since Dobbs's courts are creatures of the will of their creating sovereign: "A court does not have power to determine its own jurisdiction merely because the Supreme Court wishes it to be so; it has that power only if the legislature or constitution 'wishes' it to be so." 82 The similarities among this approach, the pre-Stoll careful parsing of jurisdictional statutes, ${ }^{83}$ and analyses of strictly jurisdictional and quasi-jurisdictional issues ${ }^{84}$ are striking; the contrast with the broad finality language of Stoll, Treinies, and Chicot $^{85}$ equally so. Nevertheless, the approach does not conflict with the holdings of the Stoll cases. ${ }^{86}$ Equally important, the approach does handle Kalb perfectly, as that case turned on a perceived congressional denial of all power to the state courts once a Frazier-Lemke

80. Bootstrap (pt. 1), supra note 79, at 1005-06.

81. Id. (pt. 2) at 1247.

82. Id.

83. See, e.g., Elliott v. Lessee of Peirsol, 26 U.S. (I Pet.) 328, 338-41 (1828); Town of Pelham v. The Schooner B.F. Woolsey, 3 F. 457 (S.D.N.Y.), aff'd sub nom. Terrell v. The Schooner B.F. Woolsey, 4 F. 552 (C.C.S.D.N.Y. 1880); Gunn v. Howell, 27 Ala. 663 (1855). Cf. pp. 165-66 \& notes 5-8 supra (discussion of English cases).

84. E.g., Noble v. Union River Logging R.R., 147 U.S. 165, 173-74 (1893); see pp. 169 70 supra.

85. See pp. 174-75 \& notes 55-57 supra.

86. Stoll, Treinies, and Chicot all rested on the general jurisdiction of the rendering court and its consequent authority to determine the extent of its jurisdiction. Chicot County Drainage Dist. v. Baxter State Bank, 308 U.S. 371, 376-77 (1940) (authority to determine jurisdiction); Treinies v. Sunshine Mining Co., 308 U.S. 66, 75-76 (1939); Stoll v. Gottlieb, 305 U.S. 165, 171-72 \& n.14 (1938). Dobbs, however, apparently does not agree with the Court on the significance of whether the jurisdictional issue was litigated in the original proceeding. He regards the question of prior actual litigation of jurisdiction as relevant only to "a judicially formulated policy of res judicata." Bootstrap (pt. 2), supua note 79 , at 1253 . By contrast, the Stoll Court distinguished a prior case involving a clear congressional denial of bankruptcy jurisdiction over insurance companies on the ground that the earlier case did not involve "an actually contested issue and order as to jurisdiction." 305 U.S. at 175-76 (distinguishing Vallely v. Northern Fire \& Marinc Ins. Co., 254 U.S. 348 (1920)). Moreover, in Durfee v. Duke, 375 U.S. 106, 114 n.12 (1963), the Court suggested that Kalb and Fidelity might now be decided differently if the jurisdictional issues were to have been litigated in the prior actions. 
petition was filed. ${ }^{87}$ The approach does less well with Fidelity, however, as Dobbs recognizes. ${ }^{88}$ But his theory has a second step, and he views Fidelity as an example of the occasional subordination of res judicata principles to more compelling policy considerations:

There was no real lack of jurisdiction involved at all; the court in question had jurisdiction to decide the merits. It should have decided the merits differently, however, and its erroneous decision so seriously affected public interests that it would be impolitic to give that judgment the normal res judicata effect. In this view bootstrap is not involved at all, nor even jurisdiction; all that is involved is a decision not to apply the normal rules of res judicata to the decision on the merits. Although the policy of sovereign immunity may have been overplayed by the Court, it is at least rational to say that the public treasury should not be raided by res judicata. ${ }^{89}$

The voidness doctrine was born in the struggles over judicial power in England and came of age in the accommodations to federal coexistence among the national and state judiciaries in the United States in the last century. With the growing emphasis on finality in this century, it has entered its dotage; it is now apparently confined to occasional forays in the name of public policy. The impact of emergent finality policies on the doctrine has been noted, but the development of a coherent doctrine from those policies-begun in Stoll, Treinies, and Chicot-was forestalled by Kalb and Fidelity. Throughout, however, the rationale of the voidness doctrine itself has remained remarkably constant: questions of jurisdiction may be found to have been conclusively determined ${ }^{90}$ or parties may be estopped to raise them, ${ }^{91}$ but those questions are nevertheless thought to be material when judgments come under attack. The jurisdiction of a court rendering a judgment is still seen as the index of its power to have done so.

87. 308 U.S. at 440. That Dobbs's approach accounts so well for Kalb is hardly surprising. One of his major criticisms of both the Restatement and Moore is that they do not deal adequately with $\mathrm{Kalb}$, and the legislative intent test was clearly constructed with Kalb in mind. See Bootstrap (pt. 2), stepra note 79, at 1249-54.

88. See Boolstrap (pts. I \& 2), supra note 79, at 1013, 1258-59.

89. Id. (pt. 2) at 1258-59.

90. E.g., Durfee v. Duke, 375 U.S. 106 (1963); Stoll v. Gottlieb, 305 U.S. 165 (1938).

91. E.g., In re Griffin, 67 Cal. 2d 343, 347-49, 431 P.2d 625, 628-29, 62 Cal. Rptr. 1, $4-5$ (1967) (Traynor, C.J.) (estoppel to attack jurisdiction of court revoking petitioner's probation, where petitioner's acts led to ouster of jurisdiction). See generally iB MoorE's Federal Practice đ 0.405[10] (2d ed. 1965). 


\section{Judicial Power and the Voidness Doctrine:}

\section{A Theoretical Framework}

Because of the continuing relationship between power and voidness, one's view of the voidness doctrine will be shaped by one's concept of the nature of judicial power. Many analyses, and especially that of Dobbs, equate jurisdiction with judicial power and thereby proceed from faulty premises. By focusing narrowly on the specific court involved in the prior proceeding, they ignore the broader question of the role of courts in general-of the judicial system-in our society. This Part examines that role in relation to the foundations of judicial power and as reflected in the structure of the American judicial system. The inquiry proceeds in two stages: the first into the powers of the judicial system as an entity and the way these powers are vested in courts, and the second into the meaning of allocations of jurisdiction among the various tribunals of the system. It will be seen that the only legitimate criterion for validity of a judgment is whether the proceedings leading to its entry comported with due process. ${ }^{92}$ There should be no such thing as a judgment void for want of subject-matter jurisdiction.

\section{A. The Origins of Judicial Power}

A society cannot function without a mechanism for the settlement of disputes.93 Moreover, as a verbal proposition, the power to "re-

92. For terminological convenience, although not without some conceptual justification, "due process" for the purposes of this Note will include all aspects of the question whether the rendering court had personal jurisdiction over the defendant. Personal jurisdiction generally has three parts, and only the first two are usually thought of in due process terms. These parts are (I) actual notice to defendant, where he can reasonably be identified, see p. 172 \& note 46 supra; (2) "sufficient contacts" between the defendant and the forum to justify exercise of judicial power ("longarm" jurisdiction), see pp. 172. 73 \& note 47 supra; (3) statutory authorization, (enumerating the bases consistent with the first two aspects upon which the court may exercise jurisdiction), e.g., Cal. Civ. Proc. Code \& 410.10 (West 1973) ("any basis not inconsistent with the Constitution of this state or of the United States"); N.Y. Civ. PRAC. Law $\$ 302$ (Mckinney 1972 \& Supp. 1976) (enumerating bases). See generally D. Louisell \&. G. HazARD, supra note 1, at 302-04. All three aspects are subject to waiver. See York v. Texas, I37 U.S. 15 (1890) (constitutionally permissible for state to treat appearance to contest jurisdiction as voluntary submission to juriscliction).

A party who did not appear in the original action must be allowed in a subsequent action to contest the original court's power to bind him to judgment, but whether duc process requires that he be allowed to contest statutory jurisdiction or only constitutional jurisdiction is not absolutely clear. It would seem logical, however, that the notice element of due process would forbid precluding a party who correctly concluded that the court did not have statutory jurisdiction over him.

93. L. Fuller, The Morality of LAw 55-56 (1964). Legal theorists of widely divergent views have recognized that all but the most primitive societies need-or, at least, seem always to have-a mechanism for the resolution of disputes. E.g., G. GiLmore, The Ages of American Law 1 (1977); H.L.A. Hart, The Concept of Law 89-91 (1961); K. 
solve" or "settle" entails finality for the resolution or settlement. As H.L.A. Hart has observed, "Disputes as to whether an admitted rule has or has not been violated will always occur and will . . continue interminably, if there is no agency specially empowered to ascertain finally, and authoritatively, the fact of violation." 94 In our society the judicial system exists to resolve disputes. "Courts to determine the rights of parties are an integral part of our system of government." 95 Indeed, the lack of a workable mechanism for resolving disputes among the states was regarded as a principal flaw of the Articles of Confederation, and the creation of a national judiciary was one of the first orders of business of the Constitutional Convention. ${ }^{96}$

Judgmental finality, then, is central to judicial power: if simply ending disputes were not a desirable social goal, there would have been no reason to establish courts to accomplish precisely that purpose. But finality cannot be the sole determinant of judicial power, for finality and "justice" are in constant tension as social goals. The assignment of dispute resolution to the judiciary can be viewed as indicative of a societal recognition that the judicial process will generally produce the correct result. ${ }^{97}$ To end disputes without a rea-

Llewellyn, The Bramble Bush 12 (3d ed. 1960); L. Pospisil, Anthropology of Law 37 (1971); cf. id. at 8-9 (noting transition to "law" from "feud" when authority exists "who either has enough power to enforce his will or possesses the skill to persuade the quarreling parties to accept his solutions"). Llewellyn came to repent of his statement that what officials do about disputes is "the law itself," K. LLEwellyN, supra at 12 (cmphasis omitted). See id. at 8-9. But nowhere in his qualification did he recant his prior assertion that " $[\mathrm{t}] \mathrm{his}$ doing of something about disputes, this doing of it reasonably, is the business of law," id. at 12.

94. H.L.A. HART, supra note 93 , at 91 .

95. Stoll v. Gottlieb, 305 U.S. 165, 172 (1938).

96. P. Bator, P. Mishikin, D. ShapiRo \& H. Wechsler, Hart \& Wechsler's The Federal Courts and the Federal System 4-6 \& nn.17-19 (2d ed. 1973) [hereinafter cited without cross-reference as HART \& WeCHSLER]. The Framers did not disagree among themselves concerning the need for courts, only concerning the need for federal trial courts. Id. at 11-12.

97. See, e.g., Summers, Law, Adjudicative Processes, and Civil Justice, in LAw, REAson, AND Justice 169 (G. Hughes ed. 1969). The judicial process-determination by an impartial tribunal, based upon evidence subject to adversary examination and aided by arguments of the parties-is not confined to courts, but it is an attribute of them. See Glidden Co. v. Zdanok, 370 U.S. 530, 544-47, 549-52, 581-83 (1962) (plurality opinion by Harlan, J.); Golding, Preliminaries to the Study of Procedural Justice, in LAw, REAson, AND Justice 71 (G. Hughes ed. 1969) (concept of "jural-like" dispute settlement, characterized by persuasive conflict before neutral third party, appears in variety of contexts). For discussions of various social decision procedures and their aims, see B. BARRY, Poittical Argument 84-93 (1965), and LaTour, Houlden, Walker, \& Thibaut, Procedure: Transnational Perspeclives and Preferences, 86 Yale L.J. 258 (1976). The parallel expansion during this century's procedural revolution, see pp. 171-73 supra, of the emphasis placed on fairness-based procedure and of the scope of res judicata doctrine suggests that the societal willingness to accede to demands for finality is related to the strength of the societal belief that the judicial system produces just resolutions of disputes. 
sonable assurance that the ends achieved will be perceived as "just" would risk undermining this support for the judicial system. But as Hart has also observed:

It is plain that the advantages of quick and final settlement of disputes ... are purchased at a price. ... The scorer [that is, decisionmaker] may make honest mistakes, be drunk or may wantonly violate his duty to apply the scoring rule to the best of his ability. ... Provision may be made for correcting his rulings by appeal to a higher authority: but this must end somewhere in a final, authoritative judgment, which will be made by fallible human beings and so will carry with it the same risk of honest mistake, abuse, or violation. It is impossible to provide by rule for the correction of the breach of every rule. ${ }^{98}$

The resolution of this tension between the desires for finality and justice in dispute resolution is precisely the object of the familiar doctrine of res judicata/preclusion. ${ }^{99}$ This doctrine stands on three bases, which can be broadly characterized as economic, institutional, and philosophical. The economic basis is the embodiment of the social need to put disputes to rest. ${ }^{100}$ It includes the policy against vexatious litigation ${ }^{101}$ and is a recognition of the large costs associated with litigation. These costs include attorneys' fees as the most obvious component, but also include expenses such as discovery and transcript costs, litigants' time, expert witnesses' fees, and so forth. ${ }^{102}$ Moreover, there

98. H.L.A. HART, supra note 93, at 139 .

99. "Preclusion" was first used in a systematic way to refer to the law of judgments by Professor Allen Vestal, who noted that the commentators seemed unhappy with the classical terminology in the field. Vestal, The Constitution and Preclusion/Res Judicata, 62 MICH. L. REv. 33, $33 \& n .5$ (1963). He suggested that the word was erocative of the central concern of determining the effect of a judgment in foreclosing subsequent litigation. Id. at 33 n.6. He has conducted extensive inquiries into the law of judgments, and his terminology is now fairly standard. See, e.g., Restarement (SECOND) of JubgMENTS $\$ \S 68,68.1$ (Tent. Draft No. 1, 1973) [hereinafter cited without cross-reference as SECond Restatement]; D. Louiseld \& G. HAZARD, supra note 1, at 636-37; Expansion, supra note 39, at $359 \mathrm{n} .7$ (1974) (citing cases). For general discussions of the policies behind res judicata/preclusion, see, e.g., FIRST Restatement \$ 1, comment a; Cleary, Res Judicata Reexamined, 57 YALE L.J. 339, $344-49$ (1948); Developments in the Law: Res Judicata, 65 HARv. L. REv. 818, 820 (1952) [hereinafter cited as Developments].

100. See, e.g., Schmieder v. Hall, 545 F.2d 768, 771 (2d Cir. 1976).

101. See Blonder-Tongue Laboratories, Inc. v. University of Ill. Foundation, 402 U.S. 313, 342-48 (1971). But cf. Cleary, supra note 99, at $346-48$ (policy against vexatious litigation may exact severe penalty for procedural failure).

102. See, e.g., Blonder-Tongue Laboratories, Inc. v. University of Ill. Foundation, 402 U.S. 313, 334-38 (1971) (costs of patent litigation); cf. Berger \& Bernstein, An Analytical Framework for Antitust Standing, 86 YALE L.J. 809, 856 n.221 (1977) (collateral estoppel provisions of Clayton Act enacted largely to reduce costs of private antitrust suits); Note, Contingent Fees for Expert IVitnesses in Civil Litigation, 86 YaLE L.J. 1680 (1977) (proposing contingent fees for expert witnesses to remove what "may be the 
are frequently strong reliance interests in judgments which need protection: for example, persons divorced may remarry ${ }^{103}$ or financial plans may be based upon the receipt of damages. ${ }^{104}$ Even though relitigation may in some cases produce benefits, those benefits are thought insufficient to compensate for the cost of the totality of extra litigation. ${ }^{105}$

The institutional basis reflects the interest of courts in preserving the integrity of the judicial system as a whole. This aspect of the interest in the finality of judgments is a matter of self-preservation: be-

litigant's largest out-of-pocket expense"). Discovery costs illustrate the strong influence of the procedural revolution on finality policies. Liberal discovery not only improves the truth-finding effectiveness of the litigation process, it also increases the cost of the process. Both effects push in the direction of finality, since relitigation becomes not only less necessary but also more expensive.

103. Divorce has been a particularly difficult problem in the law of judgments, since varying and jealously held attitudes toward the sanctity of marriage, embodied in state divorce legislation, collide directly with the full faith and credit clause, U.S. Const. art. IV, § 1. See D. Curric, Suitcase Divorce in the Conflict of Laws: Simons, Rosensticl and Borax, 34 U. CHI. L. Rev. 26, 26 (1966). The problem is not a new one-Justice Story's conflicts treatise discussed the problems caused by the sharply different divorce law of England and Scotland. J. Story, Commentaries on The Conflict of LAws 168-92 (1834). Moreover, despite the recent liberalization of many state divorce laws, see, e.g., 1966 N.Y. Laws, ch. 254 (codified as amended primarily at N.Y. DoM. REL. LAw \$ 170 (McKinney 1977)) (grounds for divorce to include cruel and inhuman treatment, abandonment, prison confinement, and separation, as well as former exclusive ground of adultery), variations still cxist, and the recent decision in Sosna v. Iowa, 419 U.S. $393,404-10$ (1975), upholding state residency requirements for divorce jurisdiction, suggests that the problems have not been entirely eliminated.

The Court has held that Stoll and Chicot principles apply to questions of divorce jurisdiction, Sherrer v. Sherrer, 334 U.S. 343, $351-53$ (1948), but state-court adherence to this rule has not been entirely wholehearted. See, e.g., Farley v. Farley, 227 Cal. App. 2d 1, 38 Cal. Rptr. 357 (1964) (portion of Utah divorce decree held void despite active participation by attacking party in prior action). For an excellent survey of questions of choice of law, jurisdiction, and recognition of judgments in divorce proceedings, see R. Crimton, D. Currie \& H. Kay, Conflict of Laws $752-848$ (2d ed. 1975).

104. See, e.g., Chicot County Drainage Dist. v. Baxter State Bank, 308 U.S. 371, 374 (1940) (reliance interest in settlement of estate of Drainage District reorganized under assertedly unconstitutional statute).

105. Presumably the attacking party perceives a positive net return for the attack, but there are other costs to consider: (a) the cost to the courts themselves, in terms of judicial and administrative time and expense, but see Cleary, supra note 99, at 348-49 (courts exist for purpose of trying lawsuits; court costs minor governmental expense); (b) the costs to the originally successful litigant, who may have been "wrong" in some metaphysical sense, but see p. 187 and notes 117 \& 118 infra, but even so should not be required to pay twice for defending himself, or indeed to pay again to retain an award already diminished by the cost of obtaining it. See Blonder-Tongue Laboratories, Inc. v. University of 11l. Foundation, 402 U.S. 313, 338 (1971).

Economic considerations are not always dispositive, of coursc. Due process-the notion of "fundamental fairness"-is properly viewed as non-cost-accountable, and relitigation must be allowed if the proceedings in the original action did not comport with due process. See, e.g., Armstrong v. Manzo, 380 U.S. 545 (1965). Moreover, cost and other finality factors are thought to have diminished significance when the judgment under attack is one of conviction of a crime. See note 131 infra. 
ing "possessed of neither the purse nor the sword," 106 the system must depend on respect-on its "moral sanction"107-to maintain its powers. ${ }^{108}$ The judicial system cannot expect respect from society at large unless its member courts respect each other. The Framers of the Constitution, keenly arvare of the judicial disorder under the Articles of Confederation, ${ }^{109}$ gave explicit recognition to this interest in the full faith and credit clause, ${ }^{110}$ which requires courts of different states ${ }^{111}$ to treat each other with respect-with "not some, but full [faith and] credit." 112 Respect by federal courts for state court processes has come to be seen as an integral part of our federal system: it is the essence of "Our Federalism," the principles of comity and federalism of Younger $v$. Harris ${ }^{113}$ and its progeny. ${ }^{114}$

106. Baker v. Carr, 369 U.S. 186, 267 (1962) (Frankfurter, J., dissenting). Justice Frankfurter echoed Hamilton. See The Federilist No. 78 (A. Hamilton) 521, 523 (J. Cooke ed. 1961).

107. Baker v. Carr, 369 U.S. 1S6, 267 (1962) (Frankfurter, J., dissenting).

108. The federal courts have sought to maintain their independence and moral sanction by refusing to adjudicate when the result would not be final. Hayburn's Case, 2 U.S. (2 Dall.) 409 (1792). See Hirt \& Wechsler 91-93; A. Bickel, The Least Dangerous BRANCH 117 (1962).

Some states have explicit constitutional provisions permitting advisory opinions by their Supreme Court, e.g., Mass. Const. pt. 2, ch. III, art. II. For a discussion of the impact of such provisions on the prestige of the courts rendering them, see HART \& WECHSLER 69-70.

109. See The Federalist No. 22 (A. Hamilton) 135, I43-44 (J. Cooke ed. 1961); Hart \& WECHSLER 4-6 \& nn.17-19.

110. U.S. CoNST. art. IV, \$ 1 .

111. The constitutional provision mentions only states, but Congress early extended the notion of full faith and credit to include the federal courts, and the extension has remained in effect since 1790. Act of May 26, 1790, ch. 11, I Stat. 122 (current version at 28 U.S.C. $\$ 1738$ (1970)); see Degnan, supra note 39, at 743-44 \& n.15.

The squabbling that results when full faith and credit is not taken seriously is well illustrated by Porter v. Porter, 101 Ariz. 131, 416 P.2d 564 (1966), cert. denied, 386 U.S. 957 (1967), and Porter v. Wilson, 419 F.2d 254 (9th Cir. 1969), cert. denied, 397 U.S. 1020 (1970). See generally Ginsburg, Judgments in Search of Full Faith and Credit: The Last-in-Time Rule for Conflicting Judgments, 82 HARv. L. REv. 798 (1969).

112. Davis v. Davis, 305 U.S. 32, 40 (1938). See also Sherrer v. Sherrer, 334 U.S. 343, 354-55 (1948) ("Nor do we understand the decisions of this Court to support the proposition that the obligation ... amounts to something less than the duty to accord full faith and credit to decrees of divorce entered by courts of sister States.") (footnote omitted; emphasis in original).

113. 401 U.S. $37,44-45,52-54$ (1971) (federal courts may not stay or enjoin pending state criminal proceedings except under spccial circumstances).

114. Cf. NLRB v. Nash-Finch Co., 404 U.S. 138, 146 (1971) (purpose of Anti-Injunction Act, 28 U.S.C. $\$ 2283(1970)$, to "avoid unseemly conflict between the state and the federal courts").

Post-Younger cases have enlarged the category of state proceedings protected from federal court interference. E.g., Juidice v. Vail, 97 S. Ct. 1211 (1977) (supplemental proceedings by judgment creditors); Huffman v. Pursue, Ltd., 420 U.S. 592 (1975) ("quasicriminal" action); O'Shea v. Littleton, 414 U.S. 488, 499-502 (1974) (bond, sentencing, and jury-fee practices of state magistrate and judge).

Underlying the Younger cases is the conviction that state courts are compctent to decide federal questions when called upon to do so. See Stone v. Powell, 428 U.S. 465, 
The philosophical basis of preclusion theory is a recognition that human beings have not been granted awareness of ultimate truth. The judicial system is designed to arrive at answers by a certain process, and there is no meaningful way it can check the correctness of those answers by the same process. As the Court held in Stoll, "[a]fter a party has his day in court, with opportunity to present his evidence and his view of the law, a collateral attack upon the decision ... merely retries the issue previously determined. There is no reason to expect that the second decision will be more satisfactory than the first." 115 This conclusion highlights the distinction between what Brian Barry has called "procedural fairness" and "background fairness"; that is, between adherence to the rules of a truth-determination procedure and satisfaction with the result. ${ }^{116}$ The philosophical basis recognizes that an opinion as to the correctness of a result cannot affect the legitimacy of the result's existence. ${ }^{11}$ Finality must be a functionof procedural fairness, not background fairness. ${ }^{118}$

These bases are powerful impulses toward finality in judicial decisionmaking. Although the technical doctrines of res judicata/preclusion-the doctrines of "claim" and "issue" preclusion"119-are not abso-

493 n.35 (1976); Huffman v. Pursue, Ltd., 420 U.S. 592, 604 (1975). Contra, Neuborne, The Myth of Parity, 90 HARv. L. Rev. 1105 (1977). For recent discussions of the development of the Younger Doctrine, see Fiss, Dombrowski, 86 YALE L.J. 1103 (1977); Friendly, Federalism: A Foreword, 86 YALE L.J. 1019 (1977); Developments in the Law -Scction $19 S 3$ and Federalism, 90 Harv. L. Rev. 1133, 1274-1330 (1977).

115. Stoll v. Gottlieb, 305 U.S. 165, 172 (1938).

116. B. Barry, Political Argument 102-06 (1965).

117. These considerations, of course, apply to appellate review as strongly as they do to other forms of review. But there are legitimate reasons for providing appellate review, and it is not unreasonable to think of such review as a continuation of the process rather than a reinitiation of it. See, e.g., Bator, Finality in Criminal Law and Federal Habeas Corpus for State Prisoners, 76 Harv. L. REv. 441, 453-54 (1963) (appellate review provides uniformity apart from correcting errors). In secking to extend these considerations to non-appellate review, however, one must be mindful of Justice Jackson's epigram on the role of the Supreme Court: "We are not final because we are infallible, but we are infallible only because we are final." Brown v. Allen, 344 U.S. 443,540 (1953) (concurring in result). See also note 162 infra (distinguishing voidness attacks from appellate review).

118. See H.L.A. HART, supra note 93, at 139 (quoted in part at p. 184 supra); Bator, supra note 117 , at $446-53,455-60$.

Professor Bator was dealing with criminal cases, which are outside the scope of this Note, see note 131 infra. But his point is applicable a fortiori to civil cases. Whatever human uncertainties make it difficult to assess the correctness of results proved "beyond a reasonable doubt," those uncertainties can only be increased when results obtained by satisfying a Iesser burden are examined.

119. "Claim preclusion" encompasses the rules of merger and bar. The Second Restatement expresses the rule of merger in this way:

When a valid and final personal judgment is rendered in favor of the plaintiff:

(a) The plaintiff cannot thereafter maintain an action on the original claim or any part thercof, but he can maintain an action upon the judgment; and 
lutes, ${ }^{120}$ the bases on which they stand are clearly fundamental to the role of the judicial system as a dispute settler. Indeed, the philosophical basis provides the only satisfactory solution to the problem of Hart's drunken scorer: having made the a priori decision that the judicial process is the best way to resolve disputes "fairly" or "justly," one may thereafter inquire only whether that process has in fact been carried out. If it has not been-i.e., if the prior proceedings did not comport with due process-then an attack should be permitted, for the fundamental assumption underlying the a priori commitment of dispute resolution to the judicial system will have been avoided. But once it has been determined that due process was satisfied, further inquiry is meaningless. Such an inquiry would be an attempt to ascertain the "Facts as They Really Are,"121 an attempt that cannot succeed. Individual questions of background fairness are not material to questions of judicial power; the judicial system meets a need-resolution of disputes-and its power as a system is independent of the nature of any particular dispute. The power stems directly from the existence of disputes in general and from the recognition that the judicial process is the best all-purpose mechanism available for their resolution.

For the system to exercise this power, however, it must provide a

(b) In an action upon the judgment, the defendant cannot avail himself of defenses he might have interposed, or did interpose, in the first action.

Second Restatement $\$ 47$. Under the rule of bar, "[a] valid and final judgment rendered in favor of the defendant bass another action by the plaintiff on the same claim." Id. \$ 48. "Issue preclusion," or "collateral estoppel," is the rule that "[w]hen an issue of fact or law is actually litigated and determined by a valid and final judgment, and the determination is essential to the judgment, the determination is conclusive in a subsequent action between the parties, whether on the same or a different claim." Id. $\$ 68$.

The questions to be answered in determining whether something is to be precluded differ sharply under the two preclusion doctrines. Claim preclusion questions are normative: how much ought to be covered by a judgment in an action of the type of the prior action? Issue preclusion questions, by contrast, are descriptive: was the matter sought to be precluded covered in the first action, and to what extent? Claim preclusion addresses a judgment as a thing and seeks to determine the appropriate size of the thing. Issue preclusion deals with judgments as statements that certain atomic controversies have been resolved; the problem is to identify the controversies that were important enough to the original litigation, and sharply enough contested therein, that one may invoke the philosophical basis to say that further examination of those controversies would be meaningless. See generally F. JAMrs, supra note 1, at 549-81; D. Louiselt \& G. HAZARD, supra note 1, at 618-22, 630-35; Developments, supra note 99, at $824-50$.

120. See, e.g., Henderson v. Bardahl Int'l Corp., 72 Wash. 2d 109, 119, 431 P.2d 961, 967-68 (1967) (rejecting assertion of collateral estoppel that would result in "windfall" judgment: "the doctrine of res judicata . . . is not to be applied so rigidly as to defeat the ends of justice, or to work an injustice"); IB Moore's Federal Practice [f 0.405[11] (2d ed. 1974); SECOND Restatemint $\$ 48.1$ (exceptions to general rule of bar); id. $\$ 68.1$ (Tent. Draft No. 3 1975) (exceptions to general rule of issue preclusion).

121. Error, supra note 79, at 867; see Bator, supra note 117, at $446-49$. 
clear and unambiguous indication of when it has resolved a dispute. If there are two "final" answers to a dispute, then neither may be relied upon until the dispute between the answers has been resolved.122 The most obvious candidate to serve as the system's signal that it has spoken with finality is, of course, the final judgment, ${ }^{123}$ For the final judgment to be effective as the system's signal it is necessary that the judgment speak not merely for the court entering it but for the system as a whole. Some may object, however, that one signal cannot emerge from a system composed of fifty semi-autonomous state subsystems, all of which exist alongside the inferior federal courts. Nevertheless, careful analysis demonstrates that this nonhomogeneity is overcome by two fundamental attributes of the system: there is "one supreme Court"124 at its head, and its components all employ essentially the same process. ${ }^{125}$

Presumably, no one would disagree with the proposition that a final judgment rendered by the United States Supreme Court is valid and is the system's last word, ${ }^{126}$ no matter how "wrong" it may appear. ${ }^{127}$

122. See Martin v. Hunter's Lessce, 14 U.S. (1 Wheat.) 304, 350-5ू1 (1816) (Story, J.).

123. For the purposes of this Note, a "final judgment" will be a judgment that is treated by the court entering it as conclusive on the issues it comprehends, and as to which the time for appeal to any court having appellate jurisdiction over the rendering court has expired. See Huffman v. Pursue, Ltd., 420 U.S. 592, 608, 611 n.22 (1975). This is not the same definition as that of either Restatement, neither of which requires expiration of the time for appeal. FIRST RESTATEMENT $\$ 41$, comment d; SECOND RESrATEMENT \$ 4I, comment f. See also, e.g., Local 438, Constr. Laborers' Union v. Curry, 371 U.S. 542 (1963) (meaning of "final judgment" as regards Supreme Court appellate jurisdiction under 28 U.S.C. $\$ 1257$ (1970)); SECOND RESTATEMENT $\$ 41$, comment b (same). Nevertheless, the definition here is reasonable for the proposed use of the "final judgment" as the system's signal that it has spoken "finally and authoritatively." The Second Restatement's definition is predicated on the judgment's being "a firm and stable one, the "last word' of the rendering court," id., comment a; for the judgment to be the "last word" of the system one needs to wait until such time as the system would not be expected to speak further, i.e., until the time for appeal has expired.

124. U.S. Const. art. III, $\$ 1$.

125. It is not being suggested that the state and federal courts are identical in every respect, or that Madison's argument that federal trial courts are needed to guarantee unbiased forums in which to adjudicate federal rights is no longer valid. I M. FARRAND, The Records of the Feder IL Convention of 1787, at 124 (rev. ed. 1937) (remarks of Madison). Nevertheless, "the judicial process," as that term is used in this Note, see note 97 supra, is shared by state as well as federal courts. Cf. Stone v. Powell, 428 U.S. 465, $493 \mathrm{n.35}$ (1976) (state courts competent to adjudicate constitutional rights when called upon to do so). But cf. Neubornc, supra note 114 (arguing that Stone premise is incorrect).

126. See, e.g., In re Potts, 166 U.S. 263, 267 (1897) (where merits of case have been decided by Supreme Court on appeal, circuit court is without authority, absent leave of Supreme Court, "to grant a new trial, a rehearing or a review, or to permit new defences on the merits to be introduced by amendment of the answer").

127. Martin v. Hunter's Lessec, 14 U.S. (I Wheat.) 304, 345 (1816) (Story, J.):

From the very nature of things, the absolute right of decision, in the last resort, must vest somewhere-wherever it may be vested it is susceptible of abuse. In all 
Subsequent views as to the correctness of the result will affect the decision's value as precedent, but they cannot affect its existence as a binding resolution of the dispute that led to its entry. Moreover, for questions admitted to be solely of state law, the same may be said for decisions of state courts of last resort. They, too, speak for the system. ${ }^{128}$ Finally, the question of type-whether the question being asked is solely one of state law-is itself a federal question, to be determined, if necessary, by the Federal Supreme Court. ${ }^{129}$ It is indeed true, therefore, as Hamilton asserted in The Federalist, that the national and state judiciaries are to be regarded as "parts of one whole."130 A litigant who is not satisfied that the judgment entered against him speaks for the entire system may arrive at a court whose authority so to speak is not in doubt. If he fails to pursue that path then, as to him, the process has run its course and the system has spoken. Failure to take an appeal that would have been successful is simply one of the many mistakes or errors of judgment a litigant may make in the course of an action. ${ }^{131}$

questions of jurisdiction the inferior, or appellate court, must pronounce the final judgment; and common sense, as well as legal reasoning, has conferred it on the latter.

Cf. United States v. Shipp, 203 U.S. 563, 573 (1906) (party may not disobey Supreme Court order and thereafter defend contempt citation on ground Court was without jurisdiction; Supreme Court's jurisdiction for determination only by Court).

128. But see Tracy v. Dufrene, 240 La. 232, I2I So. $2 \mathrm{~d} 843$ (1960) (although prior quiet title judgment affirmed by state supreme court, judgment nerertheless void for want of subject-matter jurisdiction where original suit brought in wrong parish); $c$. HART \& WeChSLER 264-67 (discussing Supreme Court's power to overrule state court determinations of state law).

129. Some choice-of-law rules are constitutionally required. See, e.g., Erie R.R. v. Tompkins, 304 U.S. 64 (1938) (state Iaw in federal diversity cases); Klaxon Co. v. Stentor Elec. Mfg. Co., 313 U.S. 487 (1941) (Erie doctrine includes state conflicts rules); Johnson v. Muelberger, 340 U.S. 581,587 (1951) (under full faith and credit clause, law of rendering state determines who may attack judgment). In such cases the choice of law raises a federal question, resiewable in the Supreme Court. Id. at 585. When, however, the choice is not required, the result simply establishes the law of $X$ concerning the law of Y. H.L.A. HART, supra note 93, at 116; see Standard Oil Co. v. Johnson, 316 U.S. 481 (1942) (remanding for determination whether construction of California statute by California court rested on state or federal law).

130. The Federalist No. 82 (A. Hamilton) 553, 555 (J. Cooke ed. 1961). Sce id. No. 80 (A. Hamilton) 534,535 (independent state final jurisdiction over national causes is "hydira in government").

131. This Note addresses finality in civil cases only. The willingness to permit a criminal defendant to retrieve his earlier procedural errors by collaterally attacking his conviction creates a sharp distinction between criminal and civil finality policies. This distinction is supported by a number of basic policy considerations. There is, for cxample, a difference in societal attitudes toward deprivation of liberty and deprivation of property, a difference that was the cornerstone of Justice Brennan's opinion for the Court in Fay v. Noia, 372 U.S. 391 (1963). See id. at 432. The Court held that habcas corpus "lies to enforce the right of personal liberty." Id. at 430 . Thus even in the face of a procedural default, federal habeas "prevents the State from closing off the convicted defendant's last opportunity to vindicate his constitutional rights, thereby 
From a structural viewpoint, therefore, the availability of appellate review guarantees that the final judgment is an unambiguous signal that the system has spoken. But that review is not always available. Courts of last resort may often decline review on discretionary grounds, ${ }^{132}$ even where review is ostensibly mandatory; ${ }^{133}$ in addition, some judgments are not reviewable at all. ${ }^{134}$ Denials of discretionary review, however, are analytically similar to affirmance on the merits:

punishing him for his default." Id. at 432 (emphasis added). See Argersinger v. Hamlin, 407 U.S. 25, 37, 40 (1972) (imposition of imprisonment where accused did not have access to counsel infringes liberty without due process); Commonwealth v. Koczwara, 397 Pa. 575, 586, 155 A.2d 825, 830 (1959), cert. denied, 363 U.S. 848 (1960) (interest in liberty precludes imposition of imprisonment for vicarious violations of regulatory statute, but criminal fine permissible); Pollak, Proposals to Curtail Federal Habeas Corpus for Statc Prisoners: Collateral Altack on the Great Writ, 66 YALE L.J. 50, 65 (1956).

Moreover, the assumptions of the economic basis of preclusion theory are less persuasive in criminal cases. One need not fashion rules to protect the defendant's interest in being free from repeated litigation, since that interest has constitutional stature and is protected by the double jeopardy clause. Ashe v. Swenson, 397 U.S. 436 (1970) (Fifth Amendment protection against double jeopardy embodies collateral estoppel as constitutional requirement). The debate centers around the government's interest in finality. See, e.g., Bator, supra note 117, at 444-62; Friendly, Is Innocence Irrelevant? Collateral Attacks on Criminal Judgments, 38 U. CHI. L. REv. 142, 146-47 (1970); Note, Collateral and Equitable Estoppel of Federal Criminal Defendants, 29 Rutcres L. REv. 1221, 1225$28,1237-46$ (1976). But in such a situation, where one party's interest in finality is absolutely protected and the other's is the subject of intense debate, it is clear that the desirability of finality qua finality must be evaluated independently of the result in civil cases, where the finality interests of the opposing parties are more nearly equal.

It may be argued that the human uncertainties inherent in attempts to determine truth, which underlie the philosophical basis of preclusion theory, are as applicable to criminal finality policy as to civil. See Bator, supra note 117 , at $446-53$. But the philosophical basis relies on process as the measure of judgmental finality, see pp. 187-88 supra, and the societal interest in individual liberty has resulted in the phrase "due process of law" carrying many more implications in criminal than in civil contexts. E.g., In re Winship, 397 U.S. 358, 364 (1970) (due process requires "proof beyond a reasonable doubt of every fact necessary to constitute" crime charged). See generally G. Gunther, Cases and Materials on Constitutional Law 506-47 (9th ed. 1975). It is therefore possible to view many habeas cases as process-oriented and not precluded by the philosophical basis. See Bator, supra note 117, at 455-66. Indeed, the holding of Stone v. Powell, 428 U.S. $465,481-82$ (1976), that admission in a state criminal proceeding of evidence obtained in violation of the Fourth Amendment cannot serve as a basis for federal habeas corpus if defendant had "an opportunity for full and fair litigation of [the] Fourth Amendment claim" in the state proceedings, appears to suggest that non-processoriented collateral attacks on state convictions may no longer be permitted.

It is clear from this discussion that there are different considerations governing criminal and civil finality. Although the arguments of this Note may bear to some extent on criminal questions, they cannot of their own weight be dispositive of them.

132. E.g., Sup. CT. R. 19 (considerations governing review on certiorari); see, e.g., N.Y. Civ. Prac. LAw \$ 5602(a) (McKinney 1963 \& Supp. 1976) (appeal by permission to court of appeals). See generally HaRT \& WECHSLER 1600-29.

133. See HART \& WeChSLrR 648-62. But see Hicks v. Miranda, 422 U.S. 332 (1975) (summary action on cases within mandatory jurisdiction of Supreme Court has same precedential weight as action after plenary consideration).

134. E.g., 28 U.S.C. $\$ 1447$ (d) (1970) (order remanding removed case to state court "not reviewable on appeal or otherwise"). The problem of the unappealable judgment is complex and is examined in note 201 infra. 
the court of last resort has spoken, if only to say that it did not regard the case as important enough to command the court's full attention. But that is very close to saying that the court is satisfied to maintain the lower-court judgment as the resolution of the dispute in question, that it is satisfied to have that judgment speak for the system. In denying review the court expresses no view of the correctness of the resolution, but it does, at least in civil cases, ${ }^{135}$ affirm the existence of the resolution. A litigant who has sought Supreme Court review and has been rebuffed may feel that the system has underestimated the importance of his claim, but he cannot doubt that the system has spoken. Indeed, there is no meaningful way that it can speak further. Non-appellate review of judgments is an attempt to reinitiate the process, not carry it forward, and there is "no reason to expect that the second decision will be more satisfactory than the first."136

\section{B. Control of Judicial Power}

Few would disagree that the need to resolve disputes "finally and authoritatively" underlies the creation and continued existence of the judicial system. Professor Dobbs, for example, has recognized that "[a] judgment ought to settle a dispute, and rights and titles derived from a judgment today ought not to be overturned twenty years from now. No society can be stable if judicially secured rights are not secure at all."137 Yet the cornerstone of Dobbs's theory of bootstrap is that judicial power exists only to the extent that it is granted by the legislature or constitution. ${ }^{138}$ That formulation need not conflict with this Note's position that judicial power derives from our society's commitment to the judicial process as the fundamental dispute-settling mechanism, for "our society" is shaped and controlled by the federal and state constitutions. Nevertheless, there is a conflict, and it is a fundamental one. Dobbs, after stating his premise, does not thereafter distinguish between legislative and constitutional grants of power. This Note argues that because the judicial system derives its power from its role as the agreed-upon institutional mechanism for performing the crucial function of dispute resolution, and because that agreement is reflected in federal and state constitutions, there are constitutional restrictions on the power of legislatures to affect the finality of judgments. These restrictions sharply limit the extent to which

135. See note 131 supra.

136. Stoll v. Gottlieb, 305 U.S. 165, 172 (1938). See pp. 187-88 supra.

137. Bootstrap (pt. 1), supra note 79, at 1003 (footnote omitted).

138. Id. (pt. 2) at 1247 . 
legislatures may impose the voidness doctrine on the judicial system. The restrictions appear in different forms depending upon whether the legislative action is that of Congress addressing federal courts, that of Congress addressing state courts, or that of a state legislature addressing the courts of its state.

It is, of course, not new doctrine that there are limitations on congressional control over the federal courts. It follows from the separation of powers ${ }^{139}$ and from the nature of an independent judiciary that if the judiciary undertakes to decide a case and renders judgment, ${ }^{140}$ then its decision must be final as against legislative or executive revision. ${ }^{141}$ The entire history of constitutional jurisprudence

139. The separation need not be regarded as complete or exclusive in order to maintain that there are areas that are entirely legislative (e.g., appropriations), entirely exccutive (e.g., negotiating treaties) or entirely judicial (e.g., trying crimes). See L. JAFFE, Judicial Control of Administr.itive Acrion 28-31 (1965).

140. This Note is concerned primarily with judgments, since thcy are the judicial sytem's signal of finality, see pp. $188-92$ supra. During the pendency of Ex parte Mrcardle, 74 U.S. (7 Wall.) 506 (1869), Congress withdrew from the Supreme Court its appellate jurisdiction over a certain class of habeas corpus cases, a class that included McCardle. The Court acquiesced and dismissed the appeal, but it is important to note that final judgment had not been rendered. Of course, there was a final judgment in the court below, but since the statute withdrew appellate jurisdiction, the crucial point would have been the issuance of a mandate by the appellate court, in this case the Supreme Court. See note 123 supra. McCardle has been questioned in modern times, see Gliclden Co. v. Zdanok, 370 U.S. 530,605 n.1I (1962) (Douglas, J., dissenting); Hart, The Power of Congress to Limit the Jurisdiction of Federal Courts: An Exercise in Dialeclic, 66 HaRv. L. REv. 1362, 1364-65 \& n.14 (1953), reprinted with revised footnotes in H.ART \& W'ECHSLer 330, 330-31 \& n.l [hereinafter cited as Dialogue, to $\mathrm{H}_{\text {ART }}$ \& WeCHSLER page number only], but it has never been overruled. The lack of a final Supreme Court mandate at the time the Court dismissed the appeal places the case outside the scope of this Note, if not by very much.

141. Hayburn's Case, 2 U.S. (2 Dall.) 409 (1792) (executive revision). See Powell v. McCormack, 395 U.S. 486, 549 n.86 (1969) (quoting McPherson v. Blacker, 146 U.S. 1, 24 (1892)) ("inadmissible" to suggest that action might be taken contrary to judicial determination); H.arT \& Wechsler 91-93; The Federilist No. 81 (A. Hamilton) 541, 545 (J. Cooke ed. 1961) (“A legislature without exceeding its province cannot reverse a determination once made, in a particular case; though it may prescribe a new rule for future cases.") But cf. Calder v. Bull, 3 U.S. (3 Dall.) 386, 395-96, 398 (1798) (seriatim opinions of Paterson \& Iredell, JJ.) (no federal bar to Connecticut legislature's exercising judicial power to grant new trial in probate case).

Judicial revision is a more complex question than executive or legislative revision. Courts are frequently called upon to interpret prior judgments in new litigation, and any denial of full preclusive effect to the prior judgment is in some sense a revision of it. It is possible, however, to distinguish between judgments that are a priori subject to being ignored and those which must be contended with when they are raised in subscquent litigation. Compare Postum Cercal Co. v. California Fig Nut Co., 272 U.S. 693, 698-99 (1927) (patent proceedings under statute explicitly denying them any preclusive effect in subsequent litigation not "judicial" within meaning of Article III) with Tutun v. United States, 270 U.S. 568, 577 (1926) (naturalization proceedings “judicial" although decree subject to subsequent suit for cancellation, since, inter alia, judgment "is . . . complete evidence of its own validity unless set aside. . . It may not be collaterally attacked.") See generally HART \& WECHSLER 95-97 (discussion of problems raised by Tulun). To say that a judgment is void is to say precisely that it is subject to being ignored. 
finds its source in the statement that "[i]t is emphatically the province and duty of the judicial department to say what the law is." 142 Moreover, Professor Henry Hart, in his celebrated Dialogue, ${ }^{143}$ presented a compelling argument that all jurisdictional statutes are subject to the inherent limitation that there must be some judicial avenue open for the vindication of constitutional rights. Congress may not, by its power to control jurisdiction, do what it could not do directly; the power over jurisdiction is subject, as are all other powers of Congress, to the affirmative limitations of the Constitution. ${ }^{144}$

The foregoing restrictions limit congressional power to implement the voidness doctrine as applied to federal judgments. The Supreme Court is vested with judicial power directly under Article III; Congress may make the Court's original jurisdiction concurrent with other courts, ${ }^{145}$ but it may not contract it. ${ }^{146}$ When it comes to lower federal courts, it is the prerogative of Congress to vest judicial power or not to do so, ${ }^{147}$ but a decision to vest carries certain implications. ${ }^{148}$ In particular, though the district courts do not exercise the entire "ju-

142. Marbury v. Madison, 5 U.S. (1 Cranch) 137, 177 (1803); see United States v. Nixon, 418 U.S. 683, 703 (1974).

143. Dialogue, supra note 140 .

144. Id. at 360 .

145. Ames v. Kansas, 111 U.S. 449, 464 (1884) (dictum); Börs v. Preston, 111 U.S. 252 (1884) (dictum); see 28 U.S.C. $\$ \S 1251(\mathrm{~b}), 1351$ (1970).

146. See HART \& WECHSLER 242.

147. HaRT \& Wechsler $11-12$ \& n.46. For a development of the relationship between Congress's power to create tribunals and the strictures of Article III, see the materials collected in $i d$. at $375-418$.

148. It may not be clear what the result would be if Congress were, for example, to create only patent courts. Cf. note 201 infra (effect of sharp limitation of jurisdiction on court's ability to exercise judicial power). But Congress has not done that; the grant of general federal question jurisdiction, 28 U.S.C. $\$ 1331$ (1970), even with an amount in controversy requirement, $i d$., must signify Congress's intent to maintain the judicial power of the district courts. See Dialogue, supra note 140 , at $348-56$ (\$ 1331 and predecessors give federal courts broad powers to supervise operation of federal law in face of attempted withdrawals of jurisdiction); cf. note 189 infra (discussion of power of federal courts in some cases to proceed with actions despite acknowledged lack of jurisdiction). The power of federal courts to retain pendent claims after dismissal of the claim that was the basis of federal jurisdiction, United Mine Workers v. Gibbs, 383 U.S. 715, 725 (1966), is another indication of the federal courts' broad authority to deal with disputes brought before them. But see Aldinger v. Howard, 427 U.S. 1 (1976) (in suits under 28 U.S.C. $\$ 1343(3)$ (1970), defendants may not be joined solely to pendent claims without independent basis for (federal) jurisdiction). The ancillary jurisdiction of the federal courts in diversity cases also developed from the need to permit federal courts flexibility to act as courts. See Freeman v. Howe, 65 U.S. (24 How.) 450, 460 (1860). See generally HART \& WECHSLER 921-26, 1075-81.

Amount-in-controversy limitations on district court jurisdiction do not affect the vesting of judicial power. "They are clearly designed to save the district courts for "important" matters, and it would be incongruous to construe them as a denigration of the district courts' authority to act as courts. See In re Sawyer, 124 U.S. 200, 220-21 (1888) (dictum) (error as to amount in controversy does not render decree void). 
dicial Power of the United States," ${ }^{149}$ they do exercise enough of it so that their judgments cannot be attacked without attacking the power itself. ${ }^{150}$ This is the meaning of Des Moines: If the interest of finality is great enough so that an excess of constitutional jurisdiction (i.e., lack of diversity) is not sufficient to defeat it, ${ }^{151}$ then the "judicial Power of the United States" must have some inherent content, over and above the sum of the nine enumerated bases of federal jurisdiction. ${ }^{152}$ This residuum of power is the systemic power discussed in

149. For example, when jurisdiction is founded solely on diversity of citizenship, the district courts may not hear claims with an amount in controversy of less than $\$ 10,000$. 28 U.S.C. $\$ 1332$ (1970).

150. The relation between judgmental finality and Article III judicial power was central to the decision in Glidden Co. v. Zdanok, 370 U.S. 530 (1962) (plurality opinion of Harlan, J., joined by Brennan \& Stewart, JJ.), to give effect to congressional declarations that the Court of Claims and the Court of Customs and Patent Appeals arc "established under article III of the Constitution," 28 U.S.C. $\$ \$ 171,211$ (1970). Justice Harlan framed the test for establishment under Article III as whether the business of the tribunal under consideration is Article III business and whether "its judges and judgments are allowed the independence there expressly or impliedly made requisite." 370 U.S. at 552 (plurality opinion). There was in fact majority support for this test. Sce id. at 580 (Clark, J., joined by Warren, C.J., concurring in result).

151. Since the Des Moines Court appcared merely to address the requirements of the removal statute facing it (Act of March 2, 1867, ch. 196, 14 Stat. 558), see 123 U.S. at 556-59, the statement that Des Moines was a constitutional case requires further exposition. There is no doubt that the statute required diversity between each plaintiff and each defendant. Hancock v. Holbrook, 119 U.S. 586 (1887). See also HART \& WECHSLER 1064 (discussion of complete diversity requirement under other statutes). It was, howcver, an open question until 1967 whether this requirement was constitutionally based. See State Farm Fire \& Cas. Co. v. Tashire, 386 U.S. 523, 530-31 (1967) (interpleader actions under 28 U.S.C. $\$ 1335$ (1970) require only minimal diverśity, i.e., any two opposing claimants having diverse citizenship). Had the Des Moines Court been concerned with the constitutional/statutory problem, it presumably would have considered whether the statute conferred the full constitutional jurisdiction. But the Court sidestepped that issuc, compare Hancock v. Holbrook, 119 U.S. 586, 587 (1887) (Waite, C.J.) (suit “cannot be removed") with Des Moines Navigation \& R.R. v. Iowa Homestead Co., 123 U.S. 552, 556.57 (1887) (Waite, C.J.) (characterizing Hancoch as holding "not error" to remand), and instead framed the issue before it as "whether, if all the parties were actually before the Circuit Court, the decree of [the Supreme Court] on appeal is absolutely void." 123 U.S. at 557. The irrelevance of the distinction to the holding in Des Moines was confirmed by the decision in Dowell v. Applegate, 152 U.S. 327, 340 (1894), that the absence of a federal question as a matter of law was not sufficient grounds to attack a judgment. But see Stoll v. Gottlicb, 305 U.S. 165, 175 (1938) (Des Moines and Dowell may have rested on existence of "color of jurisdiction" in rendering court).

152. Dobbs also regards Des Moines as fundamental. He views it as the first example of the "bootstrap principle" in operation, the first enunciation of the concept of "jurisdiction to determine jurisdiction." Bootstrap (pt. 1), supra note 79, at 1005-06. But there is a significant difference between the definition of judicial power of this Note and the first step of bootstrap. Semantically at least, jurisdiction to determine jurisdiction is still a form of jurisdiction, and hence can be controlled by anyone with control over jurisdiction. In particular, since Congress can to a limited extent control the jurisdiction of state courts, e.g., 28 U.S.C. $\$ 1334$ (1970) (district court jurisdiction of bankruptcy matters "exclusive of the courts of the States"), it can, under bootstrap, control jurisdiction to determine jurisdiction to the same extent. That was effectively the Court's reasoning in Kalb, and it is the explicit basis for the first step of bootstrap. 
the previous section, as vested in the system's component courts.

With respect to state legislatures speaking to state courts, it is clear that the preceding argument carries over to the extent that the state constitution provides for separation of powers. ${ }^{153}$ Moreover, every state has created at least one court (or, if law and equity are separately maintained, a pair of courts) with the general power to hear, with specific, limited exceptions, every claim cognizable in the courts of that state. ${ }^{154}$ As was the case with respect to federal courts, such a

See pp. 180-81 supra. Judicial power, on the other hand, is an attribute of the court qua court, of the court as a member of the judicial system. It can only be vested or removed by the entity creating the court. See pp. 197-200 infra. Dobbs would find it nccessary to determine on a case-by-case basis whether a court has jurisdiction to determine its jurisdiction over each claim coming before it (albeit that it almost always would), whereas a determination, once made, that a court exercises judicial power should stand against all but the most drastic amendment of the court's organic act.

This formulation of judicial power is similar to but broader than Dean Gavit's depiction of a court without jurisdiction as a common-law arbitrator, see Gavit, supra note 78. Gavit recognized the need for finality in dispute resolution, id. at 387,390 , but the arbitration model fails to accord the result the weight of a judgment and thus does not eliminate all obstacles to finality. See Bootstrap (pt. 1), supra note 79, at 1014 \& n.41. The formulation is also broader than the "general, superior jurisdiction" that was so crucial to the presumption of validity through the nineteenth century, see note 11 supra. The judicial power discussed here is an attribute of the court, not of the form of proceeding.

153. Some state constitutions provide for separation explicitly. E.g., MAss. Consr. pt. 1, art. XXX. Others do not make such explicit provision, but have been held to have an implied provision for separation. See, e.g., In re Greene, 166 N.Y. 485, 492, 60 N.E. 183, 185 (1901) (dictum). It is worth noting, however, that it has not always been the case that every state provides for separation either implicitly or explicitly. Sce Calder v. Bull, 3 U.S. (3 Dall.) 386, 395-96, 398 (1798) (seriatim opinions of Patcrson \& Iredell, JJ.). See generally Springer v. Philippine Islands, 277 U.S. 189, $201-02$ (1928).

154. Ala. Code tit. 13, § 126 (1959); Alaska Stat. \$ 22.10.020 (1976); Ariz. Const. art. 6, § 6; Ark. Stat. ANN. $\$ \$ 22-301,-401,-405$ (1964); Cal. Const. art. 6, $\$ 5$; Colo. Consr., art. VI, \$ 9; ConN. Gen. STAT. \$ 52-10 (1977); DeL. CoNsr. art. IV, \$\$ 7, 10; Del. Code tit. 10, $\$ \$ 341,541$ (1974); FLA. Const. art. 5, $\$ 5$; GA. CodE ANN. $\$ 24-2615$ (1976); Haw. Rev. Stat. \$ 603-21.5 (Supp. 1975); Idaho Code \$ 1-705 (Supp. 1976); Ill. Coxsr. art. 6, $\$ 9$; IND. CodE ANN., tit. 33 passim (1975) (one section of Code per county); Iowa Code Ann. $\$ 602.1$ (West 1975); Kan. Stat. $\$ 20-301$ (Supp. 1976); Ky. Rev. Stat. $\$ 23.010$ (1970); LA. Const. art. 5, § 16; Me. Rev. Stat. Anv. tit. 4, § 105 (West Supp. 1976); MD. Const. art. IV, $\$ 20$; Mass. AnN. Laws ch. 212, $\$ 4$ (Michic/Law. Co-op 1974); Mich. Comp. Laws Ann. $\$ 600.605$ (1968); Mins. Stat. Anv. $\$ 484.01$ (West 1971); Miss. Code Ann. § 9-7-81 (1972); Mo. ANN. Stat. \$ 478.070 (Vernon 1952); Mont. Const. art. VII, $\$ 4$; Neb. Rev. Stat. $\$ 24-302$ (1975); Nev. Rev. Stat. $\$ 3.190$ (1975); N.H. Rev. Srat. ANN. $\$ 491.7$ (Supp. 1973); N.J. Consr. art. 6, $\$ 3$, i 2; N.M. Const. art. VI, $\$ 13 ;$ N.I. Jud. Law $\$ 140-b$ (McKinney 1968); N.C. ConsT. art. IV, $\$ 12(3)$; N.D. Co.sT. $\$ 103$; Ohio Rev. Code ANN. $\$ 2305.01$ (Page Supp. 1976); Okla. Const. art. 7, $\$ 7(a)$; Ore. Consr. of 1857, art. VII, $\$ 9$ (now of statutory force only, but still in effect, see ORE. Const. art. 7, § 2); PA. CoNst. art. 5, § 5; R.I. Gen. LAws \$§ \$-2-13, -14 (1969 \& Supp. 1976); S.C. Const. art. V, $\$ 7$; S.D. CoNST. art. V, $\$ 5$; TENN. Code ANN. $\$ \$ 16-501,-502$, $-511,-601,-602$ (1955 \& Supp. 1976); TEx. Rev. Civ. St.It. ANN. art. 1909 (Vernon 1964); UTaH Code ANN. \$78-3-4 (1977); VT. STat. ANN. tit. 4, 113 (Supp. 1977); V.1. Code $\$$ 17-123 (1975); WASH. Rev. CodE ANN. \$ 2.08 .010 (1961); W. VA. Codr \$ 51-2-2 (1966); Wis. Stat. AnN. $\$ 252.03$ (West 1971); Wyo. Const. art. V, $\$ 10$. See Dialogue, supra note 140 , at 359.60. States maintaining the law/equity division gencrally provide for transferring causes brought in the wrong forum. See, e.g., ARk. STAт. AN. \$ $\$ 2-405$ (1962); Texin. Code ANN. \$16-511 (Supp. 1976). 
vesting of judicial power in a court is inconsistent with a legislative imposition of the voidness doctrine on the judgments of that court. Where the vesting is constitutional, ${ }^{155}$ a legislative attempt to impose voidness is forbidden; where the vesting is merely statutory, such an attempt is still inconsistent with the grant and may violate the state's separation of powers doctrine as well.

The question of congressional attempts to impose voidness on state judgments is not so straightforward as the purely federal or purely state questions. Federal/state relations fluctuate constantly, and it is extraordinarily difficult to separate questions of power from questions of prudence in the Court's recent federalism decisions. ${ }^{156}$ This is a quagmire that may be avoided here, however, for it is reasonably clear from the preceding discussion and from the history of the Tenth Amendment that if a state vests judicial power in one of its courts, Congress may not impose voidness on that court's judgments.

Whatever view one takes of the substantive effect of the Tenth Amendment in other areas, ${ }^{157}$ there is no doubt that the common law, as a body, was reserved to the states and to state courts, with federal courts available only if the action or the parties fall under one of the nine heads of federal jurisdiction. ${ }^{158}$ Moreover, the debates over ratification of the Constitution make clear that protection of the state judiciaries was an important reason behind the inclusion of the Tenth Amendment in the Bill of Rights. ${ }^{159}$ This being the case, it is doubt-

155. E.g., N.J. Covst, art. 6, § 3, โT 2, 3.

156. See Fiss, supra note 114 , at 1137 n.108.

157. See, e.g., National League of Cities v. Usery, 426 U.S. 833 (1976) (Tenth Amendment bars application of amendments to Fair Labor Standards Act to state employees); Dorsen, The National No-Fault Motor Vehicle Insurance Act: A Problem in Federalism, 49 N.Y.U.L. REv. 45 (1974) (arguing against federally mandated adoption by all states of "no-fault" vehicle insurance scheme).

158. Eric R.R. v. Tompkins, 304 U.S. 64, 78-80 (1938); see The Federalist No. 82 (A. Hamilton) 553, 554 (J. Cooke ed. 1961); id. No. 83 (A. Hamilton) 558, 561-62; Friendly, In Praise of Erie-And of the New Federal Common Law, 39 N.Y.U.L. Rev. 383, 394-97 (1964).

159. There was great concern expressed during the ratification debates that the federal judiciary would supersede that of the states. See, e.g., Centinel I, Independent Gazettcer (Oct. 5, 1787), reprinled in 2 The Documentary Histoky of the Ratification of THE CoNstitution 158, I62-63 (M. Jensen ed. 1976) (fear that appellate jurisdiction and supremacy clause would combine to place all power in federal judiciary, as control over jurisdiction had secured power of royal courts in England). Similarly, in North Carolina, an antifederalist called for an explicit recognition that "what is not given up to the United States will be retained by the individual states," fearing that otherwise "[t]he state judiciaries will have very little to do. . . As all officers are to take an oath to support the general government it will carry every thing before it." North Carolina Convention Debates, July 28, 1788, reprinted in 2 B. Schwartz, The BiLL of Rights: A Documentary History 937 (1971). Indeed, the Tenth Amendment was the only proposal contained, in one form or another, in each of the eight state proposals for a Bill of Rights. 2 B. Schwariz, supra at 1167.

The Federalists insisted that the nature of the proposed Constitution itself was suf- 
ful that Congress could deprive the states of the power to create courts to administer that body of law. The observation that "[1]aws are a dead letter without courts to expound and define their true meaning and operation"160 is as applicable to state law and state courts as it is to the federal law to which it was originally addressed.

In order for state courts to "expound and define" state law, however, the decision of a state court of last resort ${ }^{101}$ must be a final, unassailable judgment. ${ }^{162}$ This says no more than that state courts are members of the judicial system. The system's signal of finality is the judgment of one of its component courts, and if those judgments may be attacked after they have ostensibly become final-after the system has announced that the underlying dispute is settled-then the system is not settling disputes, it is offering tentative suggestions. It is to be emphasized that a statement that a judgment is void is more than a refusal to give it current effect. It is, rather, an assertion that the prior dispute could only have been settled in one way, since a contrary settlement will be denied to exist. This is an attempt to substitute background fairness for procedural fairness as the measure of finality; whenever it is successful it introduces a systematic indeterminacy into a process whose goal is determinacy. Congress may, as it has, empower litigants to remove federal cases from state to federal courts; ${ }^{163}$ Congress may, as it has, empower a federal court to enjoin state proceedings "where necessary in aid of its jurisdiction, or to pro-

ficient to guarantee state judicial integrity. See The Federalist No. 82 (A. Hamilton) 553,554 (J. Cooke ed. 1961) ("The state courts will retain the jurisdiction they now have, unless it appears to be taken away in one of the enumerated modes."); id. at 555 ("state courts will be divested of no part of their primitive jurisdiction, further than may relate to an appeal"). Despite this insistence. however, when Madison introduced his proposed Bill of Rights in the First Congress he conceded that the desire for explicit confirmation of the structural implications was legitimate. Speech before House of Rep., June 8, 1789, reprinted in 2 B. Schwartz, supra at 1033 . For a different construction of the Tenth Amendment, see I W. Crosskey, Politics and the Covstitution in the History of THE UNITED States 675-708 (1953). See generally Choper, The Scope of National Power Vis-à-Vis the States: The Dispensability of Judicial Review, S6 YALE L.J. 1547, 1611-21 (1977).

160. The Federalist No. 22 (A. Hamilton) 135, 143 (J. Cooke ed. 1961).

161. Or the decision of a lower state court, so long as there is a path of appellate review to the top of the state system and subject always to federal appellate review of federal questions, real or imagined. See note 201 infra.

162. This is not to say, of course, that Congress may not grant the federal courts appellate jurisdiction over the state courts. So much, at least, was settled in Martin v. Hunter's Lessee, 14 U.S. (1 Wheat.) 304 (1816). But holding a judgment void is different from reversing it on appeal. A characteristic of the voidness doctrine is that it operates after the time for appeal has expired. See Bootstrap (pt. 1), supra note 79, at 1003 \& n.4. Indeed, voidness attacks generally occur in a court that does not have appellate jurisdiction over the court that entered the original judgment. See, e.g., Atlantic Coast Line R.R. v. Locomotive Engineers, 398 U.S. 281, 296 (1970).

163. 28 U.S.C. $\$ \S 1441-1444$ (1970). 
tect or effectuate its judgments." ${ }^{164}$ But Congress may not, as it has on occasion attempted to do, ${ }^{165}$ displace the judgmental finality of the state courts. That is a direct attack on the basis of their judicial power and is barred by the Tenth Amendment. ${ }^{160}$

There are some problems in creating a doctrine of indefeasible judicial power based on the Tenth Amendment. Although the draftsmen did indeed see the Tenth Amendment in part as a protection of state judicial power, they might not have accepted the argument, made above, that it defeats the voidness doctrine. The doctrine did exist in England at the time of the Revolution, ${ }^{167}$ and there is no indication that the Framers intended to reject it entirely. But it is not at all clear what voidness doctrine, if any, the Framers intended to adopt, or, indeed, whether they thought about the issue at all. What is clear is that every decision concerning questions of judicial power made in the drafting of the Constitution came down on the side of finality. From the full faith and credit clause to the existence of "one supreme Court" as federal umpire, the Constitution reflects the concern of the Framers that the indecision of the Confederacy not be repeated. ${ }^{108}$ Thus although the nature of judicial power is an evolving concept, the Tenth Amendment's protection of state judicial power may appropriately be viewed as evolving in tandem with the power itself. ${ }^{109}$

164. 28 U.S.C. $\$ 2283$ (1970).

165. See pp. 176-77 supra; pp. 211-16 infra.

166. But cf. Fitzpatrick v. Bitzer, 427 U.S. 445 (1976) (enforcement powers granted Congress under $\S 5$ of Fourteenth Amendment override state's Eleventh Amendment immunity to suits in federal courts). If Congress were to couple a grant of exclusive jurisdiction with a finding that exclusivity is necessary to guarantee some Fourteenth Amendment right, and if that finding were sustained as a valid exercise of $\S 5$ enforcement power, then the Tenth Amendment restriction might well be circumvented. The closest Congress has come to doing so, however, has been to enact the removal provisions of the Civil Rights Act of 1866, ch. 31, $\$ 3,14$ Stat. 27 (current version at 28 U.S.C. $\$ 1443(1970)$ ). That statute received a narrow construction in City of Greenwood v. Peacock, 384 U.S. 808 (1966), although removal was allowed in the companion case of Georgia v. Rachel, 384 U.S. 780 (1966).

167. See pp. 165-66 supra.

168. See HART \& WECHSLER 6 n.19.

169. Cf. W. Wilson, Constitutional Government in the United States 173 (1908) ("The general lines of definition which were to run between the powers granted to Congress and the powers reserved to the States the makers of the Constitution were able to draw with their characteristic foresight and lucidity; but the subject-matter of that definition is constantly changing ....")

For example, it is clear that so far as state sovereign power is concerned, provision of a fair opportunity to litigate is all that is required for a court to bind a party over whom it has personal jurisdiction. Durfee v. Duke, 375 U.S. 106 (1963); Sherrer v. Sherrer, 334 U.S. 343 (1948); Treinies v. Sunshine Mining Co., 308 U.S. 66 (1939); see notes 56, $77 \& 103$ supra. Thus, at least in full faith and credit cases, process has replaced sovereign prerogative as a defining attribute of judicial power. $C f$. pp. 172-73 supra (development of longarm jurisdiction). 
There is nothing in the Constitution to require a federal court/ state court voidness doctrine, especially since the option was left to Congress not to create inferior federal courts at all.170 Moreover, Professor Degnan has argued persuasively that the federal/state full faith and credit statute ${ }^{171}$ is actually declaratory of an underlying constitutional norm, the same norm as constitutional state/state full faith and credit. ${ }^{172}$ If this is the case, then state/state and federal/state full faith and credit should be analyzed in pari materia. Due process is a constitutional limitation on state judicial power, but the Tenth Amendment may reasonably be said to protect that power from nonconstitutional attacks. If one looks at the judicial system not merely as a collection of separate subsystems tied loosely together by Supreme Court review, but rather as a whole-the fundamental dispute-settling mechanism of our society, its pieces united by a common processthen the Tenth Amendment does nothing more or less than guarantee to the states the right to be a part of the system. A court, when deciding a case, is settling a specific dispute between specific parties. If unappealed, its decision is final. It follows that a court vested with judicial power by its creating entity can never be said to have entered a judgment void for want of subject-matter jurisdiction. The court simply has not acted beyond its powers.

\section{The Proper Interpretation of Jurisdictional Statutes}

The preceding discussion has developed a theory of judicial porver largely immune to legislative incursion. It does not follow from that theory, however, that legislative statements as to jurisdiction are meaningless, that all jurisdictional statutes are unconstitutional abridgments of judicial power. Indeed, such a conclusion would be as severe an attack on the legislative role of ordering society in the large as the voidness doctrine is on the judicial role of resolving individual disputes. It remains to provide an interpretation of jurisdictional statutes consistent with both of these roles.

When a legislature grants or denies a court jurisdiction over a class of actions, it must define that class in some way. Moreover, one cannot determine whether a court has jurisdiction over the subject matter of an action without first determining what is "the subject matter" of the action. At the very least, therefore, a statute allocating jurisdiction over a certain class of actions becomes a part of the sub-

170. See HART \& WeChSLER 11-12 \& n.46.

171. 28 U.S.C. $\$ 1738$ (1970).

172. See Degnan, supra note 39, at 749-55. For development of this form of constitutional argument, see C. Black, Structure and Relationship in Constitutional Law (1969). 
stantive law governing that class. The allocation statute does not reach ultimate judicial power, but neither is it merely hortatory. Under the theory of this Note, it is still error for a court to exceed its jurisdiction.

But jurisdictional statutes need not be confined to the same ambit as other statutes; there is yet room to accord jurisdictional statutes a special status without infringing on judicial power. Such statutes do not merely speak of classes of actions, they speak of classes of actions in conjunction with courts. ${ }^{173}$ Due respect for the legislature, therefore, requires that courts treat jurisdictional statutes with respect, thereby avoiding confrontations on the level of naked judicial power wherever possible. It is thus entirely appropriate that questions of jurisdiction be raised by a court sua sponte ${ }^{17 t}$ or for the first time on appeal. ${ }^{175}$ Motions to dismiss for want of jurisdiction can generally be heard and resolved expeditiously, ${ }^{176}$ and can form the basis for interlocutory appellate review either by statutory procedure ${ }^{1 \tau i}$ or by writ of mandamus or prohibition. ${ }^{178}$ These procedural devices may have evolved as devices to curb excesses of power, ${ }^{179}$ a concept essentially meaningless under the theory of this Note, but they should nevertheless be retained. For until a dispute has been resolved by a final judgment, it is proper for courts to defer to the greatest extent possible to the legislative will. ${ }^{1 s 0}$ Once the resolution becomes final, however, the earlier special focus on questions of jurisdiction provides added reason not to allow a jurisdictional attack, since those questions are much less likely to have been overlooked than ones in which the court does not have its own interest to protect. ${ }^{181}$

173. See F. Frankfurter \& N. Greene. The Labor Injunction 205-14 (1930).

174. E.g., Mansfield, C. \& L.M. Ry. v. Swan, 111 U.S. 379 (1884); Dekrell v. Johnson, 404 F. Supp. 664 (E.D. Pa. 1975); Mauran v. Zoning Bd. of Review, 104 R.I. 604, 606, 247 A.2d 853, 855 (1968); see FED. R. Civ. P. 12(h)(3). Federal courts tend to pursue this possibility more seriously than do state courts. Beyond Bootstrap, supra note 79, at 492 n.6.

175. Amcrican Fire \& Cas. Co. v. Finn, 341 U.S. 6 (1951); see HART \& WECHSLER 835-40. But see note 189 infra (jurisdictional questions may appropriately be foreclosed prior to appeal in some circumstances).

176. See, e.g., N.Y. Civ. PrAc. Law \$3211(a)(2), (c) (McKinney 1970) (motion to dismiss for want of subject-matter jurisdiction available both before and after answer filed).

177. E.g., 28 U.S.C. \$ 1292 (1970); see, e.g., Burchett v. Bardahl Oil Co., 470 F.2d 793, 796 (10th Cir. 1972); Hadjipateras v. Pacifica, S.A., 290 F.2d 697, 701 (5th Cir. 1961). But see Austracan, (U.S.A.) Inc. v. M/V Lemoncore, 500 F.2d 237 (5th Cir. 1974).

178. E.g., Ex parte Peru, 318 U.S. 578 (1943); Sampsell v. Superior Ct., 32 Cal. 2d $763,766-73,197$ P.2d 739, $742-46$ (1948).

179. Sce pp. 165-60 \& note 7 supra.

180. Cf. note 140 supra (discussion of Ex parte McCardle). For a discussion of when deference might be inappropriate, see note 189 infra.

181. This argument has diminished force when the judgment was entered by default, but even in such a case there are reasons to hold the judgment binding. See p. 224 s note 282 infra. 
An exception to this analysis of jurisdictional statutes may appear to arise concerning statutes that withdraw jurisdiction in response to perceived abuses of judicial power. It may be argued that such statutes, because they represent the only method (short of mass impeachments) to curb a judiciary thought to be usurping power, should not be held to be unconstitutional. But there is no need to treat those jurisdictional statutes differently from other jurisdictional statutes.

The classic example of a legislative response to judicial overreaching occurred during the first third of this century, when federal judges were thought to be abusing their equity powers on behalf of management in labor disputes. ${ }^{182}$ Congress reacted by enacting the NorrisLaGuardia Act, ${ }^{183}$ which withdrew the jurisdiction of the federal courts to issue injunctions in labor disputes without following elaborate precautionary procedures. ${ }^{184}$ In United States $v$. United Mine Workers, ${ }^{185}$ a divided Supreme Court rejected an attempt by the union and its officers, who were cited for criminal contempt for violating a federal district court restraining order in a labor dispute, to raise the asserted lack of jurisdiction of the district court as a defense to the contempt charges. ${ }^{186}$ Justice Frankfurter, who as Professor Frankfurter had participated in drafting the Act and was largely responsible for its emphasis on jurisdiction, ${ }^{187}$ voted to sustain the convictions in Mine Workers. He emphasized that the Act had not removed the power of the federal courts to act as courts:

[N]o type of controversy is more peculiarly fit for judicial determination than a controversy that calls into question the power of a court to decide. . . .

... Only when a court is so obviously traveling outside its orbit as to be merely usurping judicial forms and facilities, may an order issued by a court be disobeyed and treated as though it were a letter to a newspaper. Short of an indisputable want of authority on the part of a court, the very existence of a court presupposes its power to entertain a controversy, if only to decide, after deliberation, that it has no power over the particular controversy....

182. See generally F. Frankfurter \& N. GReEne, supra note 173 .

183. Ch. 92, 47 Stat. 70 (1932) (codified at 29 U.S.C. $\$ \S 101-115$ (1970)).

184. 29 U.S.C. $\$ 107$ (1970).

185. 330 U.S. 258 (1947) (plurality opinion).

186. Id. at 289-95 (plurality opinion). The Court's decision had two alternative bases, neither of which commanded the support of a majority of the Court. Justice Frankfurter was the fifth vote for affirmance, joining in the second part of the Court's opinion only.

187. Smith, Judge Charles E. Clark and the Federal Rules of Civil Procedure, 85 Yale L.J. 914, 914 n.l (1976); see F. Frunkfurter \& N. Greene, supra note 173, at 199-228. 
To be sure, an obvious limitation upon a court cannot be circumvented by a frivolous inquiry into the existence of a power that has unquestionably been withheld. ... In such a case, a judge would not be acting as a court. He would be a pretender to, not a wielder of, judicial power. ${ }^{18 s}$

As Justice Frankfurter indicated, litigants are not left helpless before usurping courts. If a court deliberately ignores the legislative mandate and usurps power to impose its will in a particular way, then the judgment would be void in any case, since due process requires an impartial tribunal. ${ }^{189}$ Against anything less than such a deliberate overreaching, however, the adversary process ought to provide

188. 330 U.S. at $309-10$ (concurring in result only).

189. E.g., Gibson v. Berryhill, 411 U.S. $564,578-79$ (1973). Dobbs suggests that the Restatement's first criterion-"clear" lack of jurisdiction-may have been intended as evidentiary on the question of conscious usurpation. Bootstrap (pt. 2), supra note 79, at 1251, 1255. Equally likely, however, is that the criterion was a straightforward reaction to two cases decided early in this century: Vallely v. Northern Fire \& Marine Ins. Co., 254 U.S. 348 (1920) (clear exclusion of insurance companies from provisions of Bankruptcy Act requires purported liquidation in bankruptcy of insurance company be held void), and In re New York Tunnel Co., 166 F. 284 (2d Cir. 1908) (building companies not entitled to benefits of Bankruptcy Act, but tunnel company arguably not a building company, so lack of jurisdiction does not appear on face of record). See Stoll v. Gottlieb, 305 U.S. 165, 175 (1938) (discussion of Vallely); F. JAMEs, supra note 1, at 538-39 (comparing Vallely and New York Tunnel). There is also a discussion in Chicot of possible reasons why the jurisdictional statute involved there might not have been unconstitutional as applied to the proceedings being attacked, 308 U.S. at 377. That discussion might have provided a more immediate basis than Vallely and New York Tunnel for the selection of the first criterion in the Restatement's test.

Since the test is the impartiality of the tribunal, one must consider the effect of a court's consciously usurping power for reasons not related to prejudgment of the litigation. It may be difficult to imagine a benign usurpation, but one arguably occurred in Di Frischia v. New York Central R.R., 279 F.2d 141 (3d Cir. 1960), which reversed a judgment dismissing the action for want of diversity. The parties had stipulated the requisite jurisdictional facts and extensive pretrial proceedings had been held, and after the statute of limitations had run the defendant sought to withdraw the stipulation and dismiss the action. The district court acquiesced, but the Third Circuit reversed, refusing to permit defendant to "play fast and loose with the judicial machinery and deceive the courts." Id. at 144. Accord, ALI Study of the Division of JuRisdiction between State ANd Federal Courts $\S 1386$ at $64-66$, 366-74 (1969) [hereinafter cited as ALI Study]; Beyond Bootstrap, supra note 179. Di Frischia has been described as not "particularly generative," HART \& WeSCHLER 838, but the Eighth Circuit recently relied on it (and on the ALI STUDY) as support for affirming a district court's rejection of an attack on jurisdiction that was first made near the end of trial. Kroger v. Owen Equip. \&. Ercction Co., 558 F.2d 417, 425-27 \& nn.34-37 (8th Cir. 1977). See also id. at 419 \& $\mathrm{n} .2$ (admission of jurisdiction may be binding).

Di Frischia suggests that impartiality should indeed be the test and that "usurpation" may occasionally be justifiable. Courts should continue to be alert to their own excesses of jurisdiction as an exercise of that self-restraint so central to judicial integrity. They should not, howcver, hesitate to invoke their inherent powers as members of the judicial system to condition dismissals on agreement not to object to reinstitution in an appropriate forum, cf. D. Louisell \& G. Hazakn, supra note 1, at 394-95 (conditional dismissals on forum non conveniens grounds), or even to proceed to judgment in extreme cases. See Beyond Bootstrap, supra note 79, at 522-29. 
sufficient protection. If the jurisdictional issue is raised it may be preserved for appeal; if it is not raised there is little reason to treat the failure differently from other errors a litigant may make. ${ }^{100}$ Erroneous decisions on nonjurisdictional issues can be at least as troubling in terms of abuse of judicial power as are errors respecting jurisdiction. ${ }^{101}$

190. Cf. p. 190 supra (failure to appeal erroneous decision as to jurisdiction).

191. Compare In re Green, 369 U.S. 689 (1962) with Walker v. City of Birmingham, 388 U.S. 307 (1967). Green, attorney for a union involved in a labor dispute, was cited for criminal contempt by an Ohio state court for counselling disobedience to an antipicketing injunction entered in a labor dispute. He was convicted without being permitted to litigate his claim that the NLRB had exclusive jurisdiction over the dispute, and the conviction was eventually upheld by the Ohio Supreme Court, which relied on the Mine Workers doctrine, see pp. 202-03 supra. In re Green, 172 Ohio St. 269, 175 N.E.2d 59 (1961), rev'd, 369 U.S. 689 (1962). The United States Supreme Court reversed on the ground that due process forbade convicting Green for contempt without permitting him to challenge the state court's jurisdiction to enter the underlying order. 369 U.S. at 693. The Court, per Douglas, J., distinguished Mine Workers on the ground that that case arose in a federal court, and thus no issue of federal preemption was present. Id. at 692 n.l. This reasoning was criticized by Justice Harlan, joined by Justice Clark, who voted to remand solely to permit Green to demonstrate that opposing counsel and the trial judge had agreed that contempt proceedings might be used to test the court's jurisdiction. Absent such an agreement Justice Harlan would have found Mine Workers controlling. $I d$. at 693-97.

Walker arose on facts analogous to those of Green. An Alabama court issued a very broad ex parte injunction at 9 o'clock on a Wednesday night that prohibited civil rights demonstrations planned for the following Friday and Sunday. 388 U.S. at 321-22 (reprinting injunction). The defendants did not move to vacate the injunction; instead, they announced their belief that it was unconstitutional and that they could not obtain justice in Alabama courts, and the demonstrations took place as planned. Id. at 310-11, 323-24. On Monday the defendants did move to dissolve the injunction, but they were cited for criminal contempt and, as in Green, were convicted without being permitted to challenge the validity of the injunction. A sharply divided Supreme Court affirmed; Justice Stewart's opinion for the five-member majority placing great cmphasis on defendants' failure to move to vacate the injunction prior to disobeying it. Id. at 318-19. Green was distinguished in a footnote, as follows:

Relying on the pre-emptive command of the federal labor law, the [Green] Court held that the state courts were required to hear Green's claim that the state court was without jurisdiction to issue the injunction. The petitioner in Green, unlike the petitioners here, had attempted to challenge the validity of the injunction before violating it by promptly applying to the issuing court for an order vacating the injunction. The petitioner in Green had further offered to prove that the court issuing the injunction had agreed to its violation as an appropriate means of testing its validity.

Id. at 315 n.6 (emphasis in original). Chief Justice Warren, in dissent, found difficulty with the Court's seeming elevation of the close jurisdictional question in Green over the First Amendment, id. at 332, and suggested that the Court's second ground for distinguishing Green was "nothing but an attempt to alter the holding of that case," since "[t]he alleged circumstance that the court issuing the injunction had agreed to its violation as an appropriate means of testing its validity was considered only in a concurring opinion," $i d$. at 332 n.9.

A literal reading of Green and $I$ ralker suggests that the Court was indeed elevating a statutory preemption of jurisdiction over the First Amendment. The Walker Court appeared to regard as a matter of some significance the fact that " $[t]$ he . Hlabama Supreme Court has apparently never in any criminal contempt case entertained a claim of non-jurisdictional error," 388 L.S. at 319. See id. at 319-20. This sccond mention of 
It may be argued that the emphasis in this Note on litigation as the resolution of disputes between specific parties neglects third-party or general policy interests in judgments, and that one of the functions of the voidness doctrine is to preserve those interests and policies, albeit at some cost in finality. ${ }^{192}$ But although third-party interests are occasionally affected by judgments, a litigating party will not raise such interests unless it is to his advantage to do so, and there is very little to weigh against the two-bites-of-the-apple problem. ${ }^{193}$ Nothing

jurisdiction suggests that the Court may well have intended the issue to be taken seriously. If so, then Green could have behaved as did the Walker defendants and still have challenged the injunction in contempt proceedings, and such an elevation of form over substance would be a powerful argument in favor of climinating the voidness doctrine. And even if the Court's remarks on jurisdiction in Walker were not meant to carry great weight, that they werc made illustrates the obscurative effect of jurisdictional analyses. Justice Douglas made the same mistake when he cast part of his First Amendment argument in jurisdictional terms. See id. at 337-38 (dissenting opinion). See generally Error, supra note 79.

The inadequacy of a rigid distinction between jurisdictional and other types of errors has been noted by Professor Cox. Cox, supra note 78, at 110-11 ("the circumstances that should be regarded by justifying ... . disobedience [to invalid restraining orders] have no necessary relevance to the distinction between orders void because made without jurisdiction of the subject matter and orders that are merely erroncous"). Under the Cox analysis (written before Walker), the division in the Walker Court is accounted for by differing views on the relationship between the First Amendment and the state's interest in preserving public order, as well as by the varying assessments of the possibility of a successful attempt to dissolve the injunction prior to the demonstrations. The analysis also foreshadows Justice Harlan's concurrence in Green.

192. See Consent, supra note 5 , at $79 \&$ n.155. This argument frequently takes the form of giving the attacking party standing to vindicate a perceived public policy. E.g., Sherrer v. Sherrer, 334 U.S. 343, 361-63, 367 (1948) (Frankfurter, J., dissenting) (full faith and credit should not mandate recognition of foreign divorce judgments where domicile not genuinely litigated, since to do so would defeat interest of true domicile state and demean judicial system by condoning "conduct ... which, in any other type of litigation, would be regarded as perjury, but which is not so regarded where divorce is involved because ladies and gentlemen indulge in it"); Gavit, supra note 78, at 392 (state should not be bound by divorce decree of court lacking jurisdiction, but husband and wife should be bound if both appeared). But see Sherrer v. Sherrer, 334 U.S. 343, 356 (1948) ("That vital interests are involved in divorce litigation indicates to us that it is a matter of greater rather than lesser importance that there should be a place to end such litigation.") (footnote omitted).

193. The "public policy" type of third-party interest, see note 192 supra, is frequently subsumable under the interest of one of the parties. Thus, in Kalb, the Frazier-Lemke Act policy of protection for impecunious farmers, although designed in part to ease national cconomic dislocation, see 308 U.S. at 443 , operated directly for the benefit of farmer Kalb. Under such circumstances it is not unreasonable to require the party to raise the jus tertii directly or forgo its benefits. There are, it is true, policy interests that do not correspond so directly to the interest of a party, a good example being the national interest in aroiding labor unrest embodied in $\$ 1$ of the National Labor Relations Act, 29 U.S.C. $\$ 151$ (1970). Nevertheless, these interests may still be raised by the parties during the litigation, and unless the litigation is collusive and the court asleep, it is likely that the issue will not be overlooked. By appropriately limiting the ensuing judgment's scope, see pp. 206-07 infra, one may restrict its impact to the parties originally before the court. Moreover, if it is felt that the parties will not sufficiently protect an inchoate public interest, it is possible to embody that interest in a public agency. Compare NLRB v. Nash-Finch Co., 404 U.S. 138, 145 \& n.3 (1971) (federal 
said here would prevent a third party from attacking a judgment as fraudulent as against him, ${ }^{194}$ but it would be unfair to allow a participant in a fraud to back out because he does not like the results. ${ }^{195}$ A point frequently ignored by voidness decisions based upon expansive definitions of jurisdiction ${ }^{196}$ is that an inquiry into the effect of a judgment may not end with a determination of its validity. The scope of the judgment-questions such as the persons bound, the issues precluded, and the exact nature of the claim determined-must still be defined. ${ }^{197}$ Allocations of jurisdiction may indeed be relevant in determining, for example, whether a state court judgment on a state claim is preclusive of a related federal claim. ${ }^{198}$

It cannot be too strongly emphasized, however, that there is an

court may enjoin enforcement of state labor injunction at behest of NLRB, "sole protector" of national interest in labor field) with Atlantic Coast Line R.R. v. Locomotive Engineers, 398 U.S. 281 (1970) (federal court may not consistently with Anti-Injunction Act, 28 U.S.C. $\$ 2283$ (1970), enjoin enforcement of state labor injunction at behest of union, despite clear federal preemption). See also, e.g., N.Y. Civ. Prac. Law $\$ 1012$ (b) (McKinney 1976): "When the constitutionality of a statute of the state is involved in an action to which the state is not a party, the court shall notify the attorney-general, who shall be permitted to intervene in support of its constitutionality."

194. E.g., Williams v. North Carolina, 325 U.S. 226 (1945) (state allowed to attack foreign ex parte divorces); Aerojet-General Corp. v. Askew, 511 F.2d 710 (5th Cir. 1975) (collusive state judgment cannot defeat title earlier held valid by federal court); Rialto Pub. Co. v. Bass, 325 F.2d 527 (9th Cir. 1963) (certain payments under judgment voidable preference). See also First RestatemeNT $\$ 115(1)$ (equitable attacks by third parties).

195. See note 189 supra.

196. For a classic attempt to cast an issue in jurisdictional terms in order to permit collateral attack, see Walker v. City of Birmingham, 388 U.S. 307, $337-38$ (1967) (Douglas, J., dissenting).

197. See Consent, supra note 5, at $79 \&$ n.155. Most of the First Restatement is concerned with questions of scope. First Restatement $\$ \$ 41-111$. See also Second RestateMENT $\$ \S 41-76 ; i d$. (Tent. Draft No. 2, 1975) (all sections appearing); id. (Tent. Draft No. 3,1976 ) (all sections appearing).

198. E.g., Pearlstein v. Scudder \& German, 429 F.2d 1136, 1143-45 (2d Cir. 1970); Cream Top Creamery v. Dean Mrilk Co., 383 F.2d 358 (6th Cir. 1967); cf. Hutchings v. United States Indus., Inc., 428 F.2d 303 (5th Cir. 1970) (effect of prior arbitration). See generally Note, Res Judicata: Exclusive Federal Jurisdiction and the Effect of Prior State-Court Determinations, 53 VA. L. REv. 1360 (1967). See also Developments in the Law-Section 1993 and Federalism, 90 HARv. L. REv. 1133, 1330-60 (1977).

Jurisdictional questions regularly interact with scope determinations when plaintiffs endeavor to collect both tort damages and compensation awards. See, e.g., Mike Hooks, Inc. v. Pena, 313 F.2d 696 (5th Cir. 1963); Busick v. Workmen's Comp. Appeal Bd., 7 Cal. 3d 967, 500 P.2d 1386, 104 Cal. Rptr. 42 (1972). Labor cases hare produced delicate scope determinations turning on questions of jurisdiction, see, e.g., $\mathrm{New}$ Orleans Typographical Union No. 17 v. NLRB, 368 F.2d 755 (5th Cir. 1966) (prior judgment compelling arbitration, though valid, superseded by NLRB order), as have domestic relations cases, see, e.g., May v. Anderson, 345 U.S. 528 (1953) (ex parle decree granting divorce and adjudicating custody rights valid as to divorce but invalid as to custody; state may not determine custody without personal jurisdiction over defendant spouse); cf. Sampsell v. Superior Ct., 32 Cal. 2d 763, 773-81, 197 P.2d 739, 746-51 (1948) (Traynor, J.) (proposing test for determining jurisdiction over custody disputes). For a wellreasoned analysis of a case intolving both validity and scope problems, see United States v. Eastport S.S. Corp., 255 F.2d 795 (2d Cir. 1958). 
enormous difference between attacks on validity and determinations of scope. Every determination of scope starts from the assumption of a valid judgment, and the inquiry proceeds in the direction of relating that judgment to the current litigation. ${ }^{199}$ Finality is of paramount importance, but there are other factors that may enter into consideration. The process is dynamic. It is fully capable of treating a suit to enforce a judgment for the payment of money, where finality is likely to be the only consideration, differently from a private federal antitrust suit in which is raised a judgment from a related state action. ${ }^{200}$ Voidness analyses, by contrast, are entirely static. The inquiry begins and ends with the prior judgment. For the reasons discussed above, these analyses should be limited to due process questions so that the judicial system may better fulfill its role as society's ultimate settler of disputes. ${ }^{201}$

199. E.g., In re Penn Cent. Transp. Co., 384 F. Supp. 895, 914 (Sp. Ct., Reg. Rail Reorg. Act 1974) (Friendly, J.). See Second Restatement $\$ \$ 61,61.1,61.2,68$; id. § 68.1 (Tent. Draft No. 3, 1976).

200. E.g., Lyons v. Westinghouse Elec. Corp., 222 F.2d 184 (2d Cir.), cert. denied, 350 U.S. 825 (1955); see Note, supra note 198, at 1364-69.

201. Having now determined the correct way to approach jurisdictional statutes, it becomes possible to complete the analysis of the unappealable judgment and its effect on the systemic analysis of pp. 188-92 supra. It immediately becomes apparent that the appealability of a judgment may well be a factor in determining that judgment's validity. See Friedman v. State, 24 N.Y. 2d 528, 535-36, 249 N.E. 2d 369, 373-74, 301 N.Y.S.2d 484, 490 (1969) (unavailability of appeal from Court on the Judiciary factor in reaching merits of subsequent suit by ousted judge for back salary); cf. In re Stern, 235 F. Supp. 680, 683 (S.D.N.Y. 1964) (Weinfeld, J.) (attack permitted because, inter alia, "movants" timely efforts to seek appellate review were frustrated by imposition of a condition upon their right of appeal"). An unappealable judgment does not have the benefit of the regression from the premise of absolute Supreme Court validity, and must rely instead solely on the philosophical basis of preclusion theory. That basis is a powerful impetus toward finality, but it is only one aspect of the system, and unappealable judgments are therefore halfway outside the system. On a superficial level, therefore, it appears that legislatures may affect judicial power to the extent they may control appellate jurisdiction.

But if the theory of this Note is correct, one would expect to find some tension between courts and legislatures where appellate jurisdiction is concerned, and this has indeed been the case. In Ex parte McCardle, 74 U.S. (7 W'all.) 506 (1869), for example, the Court acquiesced in a withdrawal of its appellate jurisdiction over a certain class of habeas corpus cases, but it was careful to note that there were other paths of appellate review. Id. at 5I5; see HART \& WECHSLER 312 n.l. More recently, in Thermtron Prods., Inc. v. Hermansdorfer, 423 U.S. 336 (1976), the Court held that mandamus would lie to compel a district court to exercise its jurisdiction in a diversity removal case under 28 U.S.C. $\$ 1441$ (a) (1970), despite an explicit statutory command that the district court's order remanding the case to the state court was "not reviewable on appeal or otherwise," id. \$1447(d).

The proper resolution of this confrontation between legislatures and the judicial system is to regard unappealable judgments as analogous to actions of administrative tribunals for which no statutory review is provided. If a dispute arises concerning the validity of a putatively unreviewable administrative action, that dispute often may be resolved by the judicial system, whether means to secure resolution is called collateral attack, mandamus, quo warranto, or judicial review. See Oestereich v. Selective Serv. Sys. Local 


\section{Kalb and Fidelity Revisited}

This Note has argued that the basic premises of the voidness doctrine-the equation of jurisdiction and judicial power and the consequent submission of judicial power to legislative control-are faulty, that they do not give adequate recognition to the societal need for finality in dispute resolution as the foundation of judicial power. But the voidness doctrine is not dead. Despite the sweeping language the Court has used in rejecting voidness attacks in many cases, Kalb and Fidelity stand unreversed. Indeed, the Railroad Special Court recently relied on those two cases in holding void a federal district court judgment in a case over which the Railroad Court felt it had exclusive jurisdiction. ${ }^{202}$ In addition, the Supreme Court's approving citation of the Restatement's balancing test ${ }^{203}$ in Durfee v. Duke

Bd. No. 11, 393 U.S. 233 (1968) (preinduction review of draft classification permitted despite statute ostensibly denying such review); Lecdom v. Kyne, 358 U.S. 184 (1958) (NLRB action in violation of express statutory command enjoined under general commerce jurisdiction, 28 U.S.C. $\$ 1337$ (1970), despite purported exclusive nature of review under labor statutes); Dialogue, supra note 140, at 348-60. Similarly, ostensibly unreviewable judgments may be reviewed by extraordinary means, as Hermansdorfer (mandamus) and Friedman (collateral attack) demonstrate.

A similar analysis may be applied to justice courts and other courts of sharply limited jurisdiction, which have at least as much in common with the old English local courts and with administrative agencies as they do with trial courts of general jurisdiction. See L. JAFFE, supra note 139 , at $632-33$. Courts of sharply limited jurisdiction have never had the bencfit of any of the countervailing doctrines to the voidness doctrine, such as the verity-of-the-record presumption. See pp. 165-66 \& note 11 supra. Is a matter of state law their judgments are likely to be subject to greater scrutiny than judgments of the state's top-level trial courts. See, e.g., State ex rel. City of Mayfield Heights v. Bartunek, 12 Ohio App. 2d 141, 23I N.E.2d 326 (1967) (probate court not entitled to presumption of regularity when exercising special statutory jurisdiction). To the extent one is willing to regard courts of sharply limited jurisdiction as partially outside the judicial system, it is reasonable to deny their judgments the absolute validity accorded those of "judicial" courts.

Determining which courts are intended to be "judicial" may be difficult, as may be determining how much deference should be given to the views of those courts not so intended concerning their own jurisdiction. But because a court's place in the judicial system is determined by its organic statute (or constitutional provision), see pp. 194-99 supra, the difficulties engender problems solely of state law. In solving the first problem one may look for guidance to the cases devoted to determining whether a given court was a "superior" court and therefore entitled to the verity-of-the-record presumption. See A. Freemas, supra note 11 , at 92-94. To determine the degree of deference due the evaluation by a court of limited jurisdiction of the extent of its own power, any of the balancing tests-Dobbs's (legislative intent), Moore's (confidence reposed), or the Restatement's (five factors)-is likely to provide a reasonable approach.

202. Consolidated Rail Corp. v. Illinois, 423 F. Supp. 941, 947-50 (Sp. Ct., Reg. Rail Reorg. Act 1976), cert. denied, 97 S. Ct. 1111 (1977). ConRail had litigated the jurisdictional issue in the prior action, but the Special Court held that the urgency of its congressional mandate compelled it "to hold that Congress concluded that the policies supporting our exclusive jurisdiction outweigh the policies of res judicata." Id. at 950 (citing, inter alia, Fidelity and FIRST ReSTATEMENT $\$ 10$ ).

203. See p. 178 \& note 75 supra.

204. 375 U.S. 106,114 n.12 (1963). See note 77 supra. 
suggests that it has not foreclosed the option of holding judgments void on grounds other than due process. Finally, there is no doubt that Congress thinks it can provide for voiding state judgments: the 1970 Amendments to the Bankruptcy Act contain explicit voidness language. ${ }^{205}$

It follows from the theory of judicial power presented in this Note that Kalb and Fidelity are wrong and that the Bankruptcy Amendments are unconstitutional. Because the theory was developed on a rather abstract level, however, one might regard Kalb, Fidelity, and the Amendments as proof that the theory is incorrect. The goal of this Part is to show that the conflict between the cases and statutes, on the one hand, and the theory of judicial power, on the other, should be resolved in favor of the theory.

\section{A. Kalb: The Decision That Was Not}

In Kalb, it will be recalled, the Court held that Congress "intended to, and did" provide that the filing of a Frazier-Lemke Act petition should deprive state courts of all power over the filing farmer-debtor. Thus, the decree confirming the foreclosure sale of the Kalbs' farm was held to be void, since the decree had been entered while a FrazierLemke petition was pending. ${ }^{206}$ There are two reasons why that holding does not stand with full force against the theory of judicial power of this Note. First, the Court chose not to rely upon grounds for decision that would have been consistent both with its precedents and with the argument here. The Court could, and should, have decided the case on simple lack of notice/due process grounds. Second, the Court did not advert to a possible distinction between judicial power and jurisdictional allocations; its decision, therefore, does not squarely address a theory that relies upon such a distinction.

It appears from the briefs before the Court that the Kalbs had served a copy of the reinstatement order on the foreclosure judge personally prior to the confirmation hearing, and that they had filed

205. Bankruptcy Act Amendments of 1970, Pub. L. No. 91-467, $\S 3,84$ Stat. 991 (amending $\$ 14(f)$ of the Bankruptcy Act, 11 U.S.C. $\$ 32(f)(1970)$ ).

206. Kalb v. Feuerstein, 308 U.S. 433, $440-44$ (1940). See pp. 176-7 7 and notes 60, 61, \&. 64 supra.

There is some question as to whether the foreclosure court (Walworth County Court) was a court of general jurisdiction, for its organic statute conferred it with general law and equity jurisdiction only over claims for $\$ 25,000$ or less. 1907 Wis. Laws, ch. 234, $§ 1$ (quoted in Brief of the Respondents in No. 120, at 39-40, Kalb v. Feuerstein, 308 U.S. $433(1940)$ ). But the Court treated the county court as one of general jurisdiction. 308 U.S. at 439 . See also note 201 supra (vesting of judicial power in state courts matter of state law only). 
another copy with the clerk of the court on the day of the hearing. ${ }^{207}$ The hearing was adjourned indefinitely, but a week later, without further notice to the Kalbs, the court confirmed the sale.208 If this was in fact the case, the confirmation decree may well have been void for want of due process. ${ }^{209} \mathrm{On}$ this reading $\mathrm{Kalb}$ is not inconsistent with the theory of this Note, for failure of process is an appropriate-indeed, the only appropriate-reason to deny a judgment all preclusive effect. ${ }^{210}$ But the Kalb Court did not address the due process issue. ${ }^{211}$ Motivated perhaps by a desire to emphasize the importance of the substantive policies at issue, the Kalb Court preserved the void-

207. Brief of the Appellants in Nos. $120 \& 121$, at 4-5, Kalb v. Feuerstein, 308 U.S. 433 (1940).

208. Id.

209. Griffin v. Griffin, 327 U.S. 220, 228 (1946) (decree reducing alimony arrears to judgment, entered without notice to defendant husband, void for want of due process to extent of alimony accruing subsequent to husband's last court appearance). Griffin was decided six years after Kalb, but the result in Griffin followed directly from Wuchter v. Pizzutti, 276 U.S. 13 (1928). See 327 U.S. at 228 . In Kalb the crucial question as to notice was whether the state court had adjourned the confirmation hearing indefinitely or had merely reserved decision. Compare Brief of the Appellants in Nos. 120 \& 121, at 5 with Brief of the Respondents in No. 121, at 3-4. In the latter case, notice would have been immaterial, since no further hearings would have been contemplated. See Griffin v. Griffin, 327 U.S. 220, 233 (1946) (decree not void to extent it merely confirmed earlier decree as to which husband had had notice).

The Griffin Court spoke of "notice by personal or substituted service," id. at 228 (emphasis added), and one might therefore argue that active litigants such as the Kalbs may be required to obtain notice from, for example, court calendars. See, e.g., Iskovitz v. Sakran, 226 Md. 453, 174 A.2d 172 (1961). But the combination of the service of the reinstatement petition on the judge and the indefinite adjournment, plus the fact that preemption was not a suddenly raised issue-the Feuersteins did not move to initiate the sheriff's sale until after the first petition had been dismissed-suggests that the Kalbs had a reasonable expectation that nothing would happen without further notice. Griffin implies that violation of this expectation constituted lack of due process. $C$. Smith v. Smith, $427 \mathrm{~Pa}$. 535, 538, 235 A.2d 127, 128 (1967) (defendant who has been represented by several attorneys during course of action "entitled to more than mere notification in a legal journal as to the date, time and place of trial").

210. See p. 188 supra.

Dobbs suggests that "[i]f Kalb had appeared and had litigated the issue of the state court's jurisdiction .... his very appearance in the state court would have defeated the protection Congress sought to offer him, and there would be little reason not to bind him by the judgment of the state court." Bootstrap (pt. 2), supra note 79, at 1253. Dobbs does not advert to the suggestion in Durfee that the Court looks to the litigated/unlitigated distinction simply as an indication of how likely it is that the prior result concerning jurisdiction would have a colorable basis, 375 U.S. at 113-14 \& n.12. He does, however, note that the Court has on occasion regarded the distinction as significant. Bootstrap (pt. 2), supra note 79, at 1245 \& $\mathrm{n} .22$ (citing Fidelity and Stoll).

211. The Kalbs did not explicitly raise the due process issue in the Supreme Court. see Statement as to Jurisdiction in No. 120 at 1 ; Statement as to Jurisdiction in No. 121 at I; Brief of the Appellants in Nos. 120 \& 121 at 3-7, Kalb v. Feuerstein, 308 U.S. $433(1940)$, but they laid very heavy stress on the notice problem in their "Statement of the Case," id. at 5. It would not have been unthinkable for the Court to have addressed the issue sua sponle. See, e.g., Younger v. Harris, 401 U.S. 37, 40 (1971). 
ness doctrine in face of adequate alternative grounds for decision. ${ }^{212}$

In addition to overlooking the due process issue, the Kalb Court did not distinguish between judicial power and jurisdictional allocations. That is, the Court accepted that Congress, in allocating jurisdiction under the bankruptcy clause, ${ }^{213}$ could displace state courts from membership in the judicial system. The Court's only acknowledgment that there might be a federalism problem in the case was in a footnote: "That a state court before which a proceeding is competently initiated may-by operation of supreme federal law-lose jurisdiction to proceed to a judgment unassailable on collateral attack is not a concept unknown to our federal system."214 The two cases cited to support this proposition, however, were habeas corpus cases turning on flagrant denials of due process at the original trial. ${ }^{215}$ Neither case addresses the assault on the judicial system implicated when an allocation of jurisdiction is enforced after judgment in a civil action ${ }^{216}$ conducted in accord with due process. ${ }^{217}$

\section{B. Kalb Rampant: The 1970 Bankruptcy Amendments}

The problem that faced the Court in Kalb has recently resurfaced in remarkably similar form. In the 1970 Amendments to the Bank-

212. In re Green, 369 U.S. 689 (1962) (discussed in note 191 supra), was also a preemption case and also had an adequate alternative ground for decision. Indeed, the Court's language in Stoll, Chicot, Kalb, and Green emphasizes protection of federal courts and federal judgments. If the federal/state distinction is in fact part of the law in this area it should be extirpated as soon as possible. The institutional base of preclusion theory applies forcefully here. It would be unseemly for the Court to take a parochial outlook in its role as umpire of the federal system. See pp. 185.86 and notes 111 \& 114 supra.

213. U.S. Const, art. I, $\$ 8$, cl. 4.

214. 308 U.S. at 440 n.I2 (citing Moore v. Dempsey, 261 U.S. 86 (1923) and Johnson v. Zerbst, 304 U.S. 458 (1938)).

215. In Moore the Court reversed a federal district court's dismissal on demurrer of a habeas petition that alleged "that the appellants were hurried to conviction under the pressure of a mob without any regard for their rights and without according to them due process of law," 261 U.S. at 87 . The detailed allegations of the petition paint a stark picture of a judicial lynching. See id. at 87-90. Johnson involved denial of petitioner's right to counsel, 304 U.S. at 459, and was, moreover, an attempt to obtain relief from a federal conviction.

The Kalb Court in fact did a marked disservice to Justice Holmes's eloquent opinion in Moore. That opinion is cast throughout in due process language, and its only mention of the word "jurisdiction" comes in recounting the appellants' unavailing attempts to obtain habeas relief from the state Chancellor. 261 U.S. at 92 . By contrast, the dissenting opinion of Justice McReynolds, joined by Justice Sutherland, bristles with references to jurisdiction in arguing that appellants' only remedy was direct review. Id. at 94-96 (quoting Frank v. Mangum, 237 U.S. 309 (1915)). The citation of Moore and Johnson may have been meant to convey that the Court was aware of the due process issue in Kalb; if so, the effort was not one of Justice Black's more successful endeavors.

216. See note 131 supra.

217. But see pp. 209-10 and notes 209 \& 211 supra (arguing that original action in Kalb not conducted in accord with due process). 
ruptcy Act, ${ }^{218}$ Congress attempted to eliminate a method by which unscrupulous creditors took advantage of newly discharged bankrupts. After the close of the bankruptcy proceedings the creditor would sue in state court on the prebankruptcy obligation. ${ }^{219}$ Since the discharge was not self-executing, but merely established an affirmative defense to actions on the discharged debt, ${ }^{220}$ the bankrupt-generally without funds for an attorney and placing great faith in his discharge-would frequently suffer a default judgment. ${ }^{221} \mathrm{He}$ could not defeat enforcement of that judgment by asserting his discharge, for under the rules of claim preclusion ${ }^{222}$ the defense of discharge in bankruptcy, like all other affirmative defenses, merges into the default judgment. ${ }^{223}$ And even if the bankrupt did not default his victory was not assured, for the creditor could assert that the debt was nondischargeable. ${ }^{224}$ The issue of dischargeability would then be determined in the state court. Some bankrupts did contest the action against them and sustain their discharge. But many did not, and the inequity of the system had raised great concern. ${ }^{225}$

To meet this problem Congress enacted a scheme whereby the question of dischargeability of any debt would be determinable in the bankruptcy court. ${ }^{226}$ Moreover, certain frequently abused grounds for nondischargeability ${ }^{22 \pi}$ were made determinable only by the bankruptcy court, ${ }^{228}$ and only within a limited period during the bank-

218. Pub. L. No. 91-467, 84 Stat. 990 (1970) (amending $\$ \S 2,14,15,17,38,58$ of the Bankruptcy Act, 11 U.S.C. $\$ \S 11,32,33,35,66,94$ (1970)) [hereinafter cited by Bankruptcy Act section only].

219. See Bankruptcy: Hearings on S.J. Res. S8, H.R. 6665 and H.R. 12250 Before Subcomm. No. 4 of the House Comm. on the Judiciary, 9lst Cong., lst Sess. 25 (1969) [hereinafter cited as Hearings] (statement of Edward Weinfeld, United States District Judge, S.D.N.Y.); id. at 46-49 (statement of Clive Bare, Referee in Bankruptcy, E.D. Tenn.); Countryman, The New Dischargeability Law, 45 AM. BANkr. L.J. 1, 1-10 (1971). Professor Countryman was a draftsman of the 1970 Amendments. See id. at 23.

220. Hearings, supra note 219 , at 52 (interchange between Rep. Wiggins and Daniel Cowans, President, National Conf. of Referees in Bankruptcy). See N.Y. Civ. Prac. Law $\$$ 3018(b) (McKinney 1974) (pleading discharge); FED R. Crv. P. 8(c) (same).

221. Hearings, supra note 219 , at 25 (Weinfeld statement); id. at 34 (Cowans statement); id. at 47 (Bare statement).

222. See note 119 supra.

223. Countryman, supra note 219 , at 5,10 .

224. The circumstances under which a debt is nondischargeable are enumerated in \$ 17(a) of the Bankruptcy Act, 11 U.S.C. \$ 35(a) (1970).

225. See, e.g., Hearings, supra note 219 , at 12 (statement of Ernest Friesen, Dir., Admin. Off. of United States Courts) ("worst defect in the Bankruptcy Act"); $i d$. at 25 (WVeinfeld statement) (opportunity to provide bankrupt fresh start with clean slate lost).

226. Bankruptcy Act $\$ 17(\mathrm{c})$.

227. Fraud by false pretenses or use of a false financial statement, or "willful and malicious" conversion of property, $\S 17(a)(2)$; fraud by a fiduciary, $\S 17(a)(4)$; "willful and malicious" injury to persons or property, $\$ 17(a)(8)$.

228. See $\S 17(c)(2)$. The statutory language is somewhat ambiguous, but the intent is clear. See Countryman, supra note 219 , at 26. 
ruptcy proceedings. ${ }^{229}$ If the creditor did not move for a determination of nondischargeability, he could not assert any of the enumerated grounds in a subsequent action. ${ }^{230}$

The scheme is enforced in two ways. First, the order of discharge is to enjoin all creditors from suing on discharged debts. ${ }^{231}$ Second, the order must declare

that any judgment theretofore or thereafter obtained in any other court is null and void as a determination of the personal liability of the bankrupt with respect to any of the following: (a) debts not excepted from the discharge under [\$ 17(a)]; (b) debts [automatically] discharged under $[\$ 17(c)(2)]$; and (c) debts determined to be discharged under $[\$ 17(\mathrm{c})(3)]^{.32}$

The provision for the injunction is salutary, but in light of the preceding discussion of judicial power the null-and-void declaration violates the Tenth Amendment. That declaration apparently would permit a debtor facing a state court suit on a prebankruptcy debt to ignore the suit entirely and treat the ensuing judgment as a "letter to a newspaper" whether or not he could have defended the suit when it was instituted. ${ }^{233}$ In other words, the Amendments place debtors

229. See $\$$ 14(b)(1), $17(c)(2)$.

230. $\$ 17(\mathrm{c})(2)$.

231. $\$ 14(\mathrm{f})(2)$.

232. $\$ 14(f)(1)$. The three categories do not, taken together, guarantee a final determination of the dischargeability of every debt at the time the decree is entered. In addition to debts excepted under $\$ 17(a)(1),(3),(5),(6),(7)$ and not submitted for determination under $\$ 17$ (c)(1), there are those claims against the bankrupt that, in the language of the Bankruptcy Act, are not "debts" at all, because they are not provable. See $\$ \$ 1(14), 63$. Indeed, the Amendments explicitly provide for reopening bankruptcy cases for determinations of dischargeability. $\$ 17(\mathrm{c})(6)$; see Countryman, supra note 219, at 30-31.

233. See Countryman, supra note 219, at 47-48; Comment, Bankruptcy: Effect of the 1970 Bankruptcy Act Amendments on the Discharge that Never Was, 1971 W1s. L. Rev. 117.1 , 1185-87 (1971). Professor Countryman has presented the following illustration of the operation of $\$ 14(f)$ :

After Debtor gets his bankruptcy discharge, Creditor takes judgment in a nonbankruptcy court. Debtor, who had not applied to the bankruptcy court for a determination of dischargeability, does not now apply to the bankruptcy court for such a determination and for an injunction, as he might do, but defends the action. Judgment is entered for Creditor. Debtor does not appeal, but now applies to the bankruptcy court for a determination of dischargeability and injunctive relief. Traditional application of the doctrine of res judicata would lead to the conclusion that the matter may not be relitigated in the bankruptcy court, whether or not Debtor pleaded his discharge as a defense to the action. But what is the meaning of the provision that new $\$ 14 \mathrm{f}$ puts in every discharge? Any judgment "theretofore or thereafter entered is null and void as a determination of the personal liability of the bankrupt" ... [ [T]he intent of $\$ 14 \mathrm{f}$ apparently is that if the creditor asserts that his claim is nondischargeable because within any of the exceptions specified in $\$ 17 \mathrm{a}$ the prior nonbankruptcy adjudication is not res judicata.

Countryman, supra note 219 , at $47-48$ (footnotes omitted).

This hypothetical achicved actuality in In re Kaid, 347 F. Supp. 540 (E.D. Va. 1972). 
in the same position of absolute immunity to state process as were the Kalbs; the corollary-deprivation of state judicial power-is the same in both cases. It is clear from the legislative history that Congress intended to create that immunity, ${ }^{234}$ but to the extent that the statute attempts to divest state courts of their place in the judicial system, it cannot stand against the Tenth Amendment. ${ }^{235}$

Sears, Roebuck \& Co. held a security interest in some household goods purchased by Kaid; when Kaid filed a bankruptcy petition Sears obtained leave to repossess its collateral. The goods could not be found, however, and Sears filed a detinue action in state court. Kaid appeared and defended the action, represented by his bankruptcy counsel, and suffered judgment based upon an explicit finding of willful conversion. He then moved to reopen the bankruptcy case, have Sears held in contempt for prosecuting the state action after discharge, have the state judgment declared null and void and its enforcement enjoined, and obtain an attorney's fee for and costs of the state action. The court granted all the requests except the last, relying on the null-and-void provision of $\S 14(\mathrm{f})(1) .347 \mathrm{~F}$. Supp. at 543. But the court denied the attorney's fee and costs, agreeing with the state court's finding of willful conversion by Kaid and noting in addition that Kaid had slept on his rights. Id. at 544. Since Sears had also slept on its rights by not returning to the bankruptcy court after the repossession attempt failed, both parties had unclean hands; but $\$ I 4(f)$ operated to require the bankruptcy courta court of equity-to restore to the perpetrator of a fraud the benefits of his scheme. This case, the outlines of which were clearly contemplated by the draftsmen of the statute, illustrates the wrongness of the voidness doctrine, whatever one may think of its constitutionality. Not only does the doctrine constitute a direct attack on state judicial power, it also produces results which bear little relation to concepts such as fairness or equity.

234. See note 233 supra. The voidness provision and the injunction provision were in neither of the draft statutes under consideration in the 1969 hearings, see Hearings, supra note 219 , at 52, but Rep. Wiggins expressed concern that the exclusive jurisdiction provisions would be meaningless without some easily available coercive means of enforcement. Id. at 52-55. The bill was redrafted in the three weeks following the close of the hearings, see Countryman, supra note 219 , at $22-23$, and the new bill contained $\S 14(\mathrm{f})$ in its present form. See Hearings, supra note 219 , at 92.93 (letter from Lawrence P. King to Byron G. Rogers, Subcomm. Chairman; copy of new draft bill).

235. The only Tenth Amendment problem considered by the draftsmen was whether submission of an inchoate alimony claim for determination of nondischargeability would involve the bankruptcy court directly in domestic relations cases if it were to proceed to judgment under the seemingly mandatory language of $\$ 17(\mathrm{c})(3)$. See Countryman, supra note 219, at 33-34. But Professor Countryman is no doubt correct in concluding that this provision "should not be, and is not likely to be, construed as an attempt of doubtful constitutionality to confer upon the bankruptcy courts, alone among all federal courts, jurisdiction to grant divorces, determine paternity, adjudicate custody rights, and fix the amount of alimony and support obligations." Id. at 34. See IA J. MLoore \& L. King, Collier on Bankruptcy ff 17.28A[4], at 1742.4 (14th ed. 1976) (in rare case bankruptcy court may remit trial of remaining issues because of complexity or specialized nature of claim); $c f$. In re Wraller, $494 \mathrm{~F} .2 \mathrm{~d} 447,452$ (6th Cir. 1974) (in alimony case bankruptcy court "should act with caution in order not to abuse the balance between the state and federal relationship [sic|"). Professor King has characterized the injunction remedy as "perhaps [the] more important" of the two, IA J. Moore \& L. KING, supra If 14.69 , at 1453 , but it is clear that little if any thought was given to whether the voidness remedy was constitutional. The only hint of doubt appears in the Countryman hypothetical discussed in note 233 supra. Professor Countryman argues that "[ $t$ ]here is no apparent reason why Congress cannot ... provide [the voidness remedy]" in such a case since federal/state full faith and credit is merely statutory. Countryman, supra note 219, at 48 . But questions of validity of state judgments do have constitutional 
Fortunately, the unconstitutionality of the null-and-void declaration will not jeopardize the well-considered scheme of which it is a part: discharged bankrupts will not be returned to the mercy of their former creditors. Loss of the voidness remedy will have little effect on the substantive provisions of the statute. There is nothing constitutionally objectionable in the provision for the injunction against subsequent suits; it is a form of relief long known in equity. ${ }^{236}$ The injunction is enforceable via contempt proceedings. ${ }^{237}$ Hence, if the bankrupt applies to the bankruptcy court before the creditor's action goes to judgment, there would be no constitutional problem in enjoining further prosecution of that action. Indeed, such an injunction could be directed against the state court itself,, ${ }^{238}$ thereby obviating most problems of enforcement against a creditor possibly already once in contempt. ${ }^{230}$ There would then be ample time to bring the creditor into the bankruptcy court and either try him for contempt (if the debt was covered by the discharge injunction) or determine the issue of dischargeability and proceed to judgment. ${ }^{240}$ Moreover, even after

stature. See pp. 197-200 supra. Cf. Degnan, supra note 39 , at 749 (if statutory full faith and credit did not exist Supreme Court would have had to invent it). It follows that $\$ 14(f)(1)$ is unconstitutional.

236. The suit to quiet title, for example, grew up precisely to restrain abusive actions at law. See D. Louiser.l \& G. HAZARD, supra note 1, at 218.

237. See In re Kaid, 347 F. Supp. 540, 543 (E.D. Va. 1972) (holding creditor in "technical contempt").

238. Bankruptcy injunctions are "expressly authorized" exceptions to the strictures of the Anti-Injunction Act, 28 U.S.C. $\$ 2283$ (1970). Toucey v. New York Life Ins. Co., 314 U.S. 118, $132-33$ (1941). To date, the Younger Doctrine, see p. 186 \& note 114 supra, has not been held applicable to bankruptcy injunctions. But cf. Juidice v. Vail, $97 \mathrm{~S}$. Ct. $121 \mathrm{I}$ (1977) (Younger Doctrine bars suit brought by judgment debtors under Civil Rights Act, 42 U.S.C. $\$ 1983$ (1970) (held an "expressly authorized" exception to $\$ 2283$ in Mitchum v. Foster, 407 U.S. 225 (1972)), seeking to enjoin continuation of allegedly unconstitutional state procedure whereby judgment creditors may depose judgment debtors). Moreover, federal injunctions to protect discharges were given explicit sanction, at least in "unusual circumstances," during the period before 1970, when dis. chargeability was litigable in state courts. Local Loan Co. v. Hunt, 292 U.S. 234, $241-42$ (1934). See Countryman, supra note 219 , at 3. The stated purpose of the 1970 Amendments was to remove the "unusual circumstances" provision from the Local Loan doctrine so that the doctrine would apply as a matter of course. See National Bankr. Conf., Explanatory Memorandum to Accompany Bill Amending Sections 2, 14, 15, 17, 38 and 58 of the Bankruptcy Act, in Hearings, supra note 219, at 95, 97, reprinted in [1970] U.S. U.S. Cone Conc. \& Ad. News 4161, 4163.

239. Whether the creditor was in fact in contempt might depend on whether he had a good faith belief that the debt was not covered by the discharge decree, but it would be almost impossible for a commercial creditor such as a finance company to have such a belief unless the debt were not on the bankrupt's schedule of debts, see $\$ \S 14(\mathrm{f})(1)(\mathrm{a})$, 17(a)(3). All other exceptions to discharge normally applicable to such a creditor are automatically foreclosed under $\$ 17(\mathrm{c})(2)$.

240. All that would be required to effectuate this scheme is clear and insistent notice to the bankrupt, in the discharge decree itself, that he cannot afford to ignore subsequent suits, but that he will be protected easily and cheaply if he applies to the bankruptcy court. See Countryman, supra note 219 , at $45-46$. 
judgment in the creditor's action, the bankrupt could move in the bankruptcy court to enjoin enforcement of the judgment if he could show some acceptable excuse for not having proceeded before judgment. ${ }^{241}$ What is not permissible is for the bankrupt to ignore the state action entirely, with no excuse whatsoever, and then at some time in the future move to have the judgment declared null and void. ${ }^{242}$ That would indeed be a destruction of the judgmental finality guaranteed to state courts by the Tenth Amendment. Congress was worried that bankrupts might sleep on their rights and lose them, but it solved the main problem with its provision that the bankruptcy court might determine dischargeability, and it provided adequate means of enforcing the solution via the injunction against further suits.

\section{Fidelity: The Decision that Should Not Have Been}

In Fidelity the Court invalidated a judgment against the United States as trustee for the Choctaw and Chickasaw Nations. Both the Government and the Indians were protected by sovereign immunity; since the failure of their counsel to raise the issue of immunity in the prior suit was ineffective as a waiver of immunity, "the attempted exercise of judicial power [was] void." ${ }^{43}$ The case is a more difficult one than Kalb since sovereign immunity is arguably not subject to judicial determination at all. The same separation of powers argument that permits judicial decisions to be free from legislative or executive revision may be turned against the judiciary here. Courts may be regarded as on notice that whenever they deal with a sovereign they may be treading outside their assigned path. This argument, however, is not as persuasive as it might be were it possible to say that Congress had waived immunity grudgingly and had reserved to itself the power to make the ultimate determination of waiver. But the

241. Bankruptcy courts are courts of equity, see, e.g., Local Loan Co. v. Hunt, 292 U.S. 234, 241-42 (1934), and "mistake, surprise and excusable neglect" are classic reasons for equity to enjoin enforcement of a judgment. F. JAMEs, supra note 1 , at 546 . Given the clear policy behind the amendments, especially the explicit recognition given to the difficult position of a newly discharged bankrupt faced with a lawsuit, the bank: ruptcy court is likely to be disposed to find an excuse. This case-by-case treatment, no matter how liberally applied, is conceptually different from an a priori determination of voidness. Inquiry into conduct of litigants is process oriented, and is therefore in accord with the theory of this Note.

242. See note 233 supra.

243. United States v. United States Fidelity \& Guar. Co., 309 U.S. 506, 514 (1940); see p. 177 supra. The lack of competence of federal officials to waive sovereign immunity is standard doctrine. Finn v. United States, 123 U.S. 227, 233 (1887); Case v. Terrell, 78 U.S. (11 Wall.) 199, 202-03 (1871). 
various federal waivers of immunity ${ }^{244}$ have a broad scope ${ }^{245}$ and, equally important, are not limited to proceedings in the Court of Claims. ${ }^{246}$ Indeed, the holding in Glidden Co. v. Zdanok that the Court of Claims is an Article III court ${ }^{2+7}$ implies that the scope of the immunity, like justiciability and other limits on judicial competence, is an issue for judicial determination. ${ }^{248} \mathrm{~A}$ similar conclusion is warranted concerning Eleventh Amendment questions when a state appears in federal court. There are long lines of cases on both sides of the immunity issue, which involve such questions as implied con-

244. E.g., Federal Tort Claims Act, ch. 753, tit. IV, 60 Stat. 842 (1946) (codified as amended primarily at 28 U.S.C. $\$ \$ 1346(\mathrm{~b}), 2671-2680$ (1970 \& Supp. V 1975)); Tucker Act, ch. 359,24 Stat. 505 (1887) (codified as amended at 28 U.S.C. $\$ \S 1346,1491$ (1970 \& Supp. V 1975) and elsewhere in Title 28).

245. See Note, An Economic Analysis of Sovereign Immunity in Tort, $50 \mathrm{~S}$. CAL. L. REv. 515, 517 n.12 (1977) ("the federal government has, in gencral, consented to be sued").

246. See, e.g., 28 U.S.C. $\$ 1346(a)(1970)$ (concurrent jurisdiction of district courts and Court of Claims); $i d$. $\$ 1346(\mathrm{~b})$ (exclusive jurisdiction of district courts of suits under Federal Tort Claims Act). There had been at least a partial legislative waiver in Fidelity, with respect to both the federal government and the Indians, but the waiver was limited to the District Court for the Eastern District of Oklahoma, the successor to the territorial court for Indian Territory. Act of Apr. 26, 1906, ch. 1876, § 18, 34 Stat. 134 (waiver); Oklahoma Enabling Act, ch. 3335, $\$ \S 13-20,34$ Stat. 275 (1906) (establishing succession from territorial court to district court). It is not absolutely clear from the statutes whether the waiver was to devolve on the federal courts or the state courts after statehood. Compare id. $\$ \S 13,16$ (federal courts) with id. $\S 19$ (state courts). But the Fidelity Court appeared to assume that the original judgment would have been valid had it been entered by the Oklahoma federal court. See 309 U.S. at 513. This was the court in which the Government sued on the bond and in which the receiver intervened and counterclaimed on his judgment from the bankruptcy court. Thus the only question in the second suit was whether to give effect to the prior judgment as establishing the claim or to require instead that the receiver prove his claim from scratch. The Court chose the second alternative, but its attempt to explain why the waiver was to be viewed as effective only in the Oklahoma court is, in the context of a prior final judgment, unconvincing. The Court held that the waiver was conditioned on permitting the Indians to try their lawsuits close to home, 309 U.S. at 513, but the Court failed to take into account the fact that the Indians were the plaintiffs in the original action. On the other hand, the Indians did not choose that forum, since the decree was entered in an ongoing bankruptcy proceeding. Such delicate questions might well be crucial to an appeal of the bankruptcy decree, but in light of the discussion at pp. 188-90 supra, it is difficult to see why those questions should survive a final judgment. The Court did not attempt to balance finality against sovereign immunity but merely asserted that "without Iegislative action the doctrine of immunity should prevail." 309 U.S. at 515 .

247. 370 U.S. 530, 552.58, 584 (1962) (plurality opinion). There was a majority of the Court on this point. See id. at 585-89 (Clark, J., joined by Warren, C.J., concurring in result).

248. Jackson v. Irving Trust Co., 311 U.S. 494 (1941) (determination in prior suit that partnership not "enemy" within meaning of Trading with the Enemy Act, and that partnership therefore entitled to sue Alien Property Custodian under Act, may not be attacked by Government in suit to set aside decree); United States v. Eastport S.S. Corp., 255 F.2d 795, 802-05 (2d Cir. 1958) (Court of Claims determination that it had jurisdiction, in face of Government assertion that administrative procedure provided exclusive mode of redress for claimant, binding on Government; subsequent action barred by Government's failure to assert compulsory counterclaim in Court of Claims action); see pp. 1939.1 \& notes 139.42 supra. 
sent to suit. ${ }^{249}$ The absence of a blanket ban on suits, taken with the problems inherent in determining whether to imply consent to suit, establishes that the question of Eleventh Amendment immunity is again one to be resolved judicially..$^{250}$

The holding in Fidelity therefore fails to recognize the extent of judicial power, and it follows that it should be rejected. Yet it is also bad law for another reason-a reason that illustrates the essential insensitivity of the voidness doctrine to the interests it purports to advance.

In Fidelity, somebody made a mistake. The Government's counsel did not plead immunity in the first action and did not appeal the decree, and as a result two sovereign entities suffered a money judgment. Whether one reads the Supreme Court's voidness language literally or whether one agrees with Professor Dobbs that the case stands for the proposition that "the public treasury should not be raided by res judicata," ${ }^{251}$ the operative fact is that the Government and the Indians were allowed to avoid the consequences of a mistake of counsel that would have bound anyone else. But the American doctrine of sovereign immunity-at least with respect to money judgmentsstands squarely on protecting the integrity of the public fisc. ${ }^{252}$ The

249. E.g., Parden v. Terminal Ry., 377 U.S. 184, 192 (1964) (operation of railroad by state implies consent to suit under Federal Employers' Liability Act). See Note, $A$ Practical View of the Eleventh Amendment-Lower Court Interpretations and the Supreme Court's Reaction, 61 GEo. L.J. 1473, 1498 (1973) ("The single most overwhelming fact about Eleventh Amendment cases is their complete confusion.")

250. Cf. United States v. United Mine Workers, 330 U.S. 258, 309 (1947) (Frankfurter, J., concurring in result) (issues of jurisdiction "peculiarly fit for judicial determination").

The situation might well be different if a state court judgment against the United States were called into question. The United States has waived immunity to certain suits in state courts, e.g., 28 U.S.C. $\$ 2410$ (1970) (actions affecting property on which United States has a lien), but the waivers have been in no way as comprehensive as the waivers for suits in federal court, for the general tort and contract waivers are restricted to federal courts. 28 U.S.C. $\$ 1346(b)(1970)$ (district courts have exclusive jurisdiction of Tort Claims suits); see id. $\$ \S 1346(a), 1491$ (jurisdiction of suits "not sounding in tort" in district courts and Court of Claims). One may therefore regard state courts as on notice that they may be acting beyond their power when they adjudicate claims against the United States, that as far as the federal government is concerned "the judicial system" means only the federal judicial system. Cf. $i d$. $\$ 2414$ (district court judgments against United States to be paid "on settlements by the General Accounting Office"; state court judgments against United States to be paid on settlements "after certification by the Attorney General that it is in the interest of the United States to pay the same"). The arguments of this Note imply, however, that it would be inappropriate to invoke voidness to defeat a state judgment against the United States where the purported jurisdictional base was at all colorable.

251. Bootstrap (pt. 2), supra note 79, at 1259 .

252. See Land v. Dollar, 330 U.S. 731, 738 (1947) (suit is against sovereign if "judgment sought would expend itself on the public treasury or domain, or interfere with the public administration"); $c j$. Edelman v. Jordan, 415 U.S. 651, 663-68 (1974) (test for whether suit proscribed by Eleventh Amendment). See generally H.ART \& WECHSLER 1362-77. 
holding in Fidelity thus flies in the face of other cases where mistakes of governmental officials have been held to bind the government to a monetary loss. ${ }^{253}$

Two recent cases illustrate the fundamental inconsistency in allowing sovereign immunity to survive and defeat a final judgment. Jordan $v$. Gilligan ${ }^{2 \tilde{4}}$ arose out of a legislative reapportionment suit in federal court in Ohio. After a plan had been finally approved by the district court, the successful plaintiffs filed an application for attorneys' fees; the Ohio Attorney General had had notice of the aplication, but did nothing and the application was granted without objection. The state refused to pay the judgment $t^{255}$ and the plaintiffs obtained a writ of fiere facias against one of the state's bank accounts. At this point the state finally ${ }^{253}$ moved, pursuant to Rule $60(\mathrm{~b}),{ }^{257}$ to vacate the award of fees on the ground that it was prohibited by the Eleventh Amendment and therefore void. The district court denied the motion, in part because the state's failure to act earlier created a res judicata barrier to its claim of Eleventh Amendment protec-

253. In United States v. National Exch. Bank, 270 U.S. 527 (1926) (Holmes, J.), a check drawn by the United States on itself in the amount of $\$ 47.50$ was fraudulently raised to $\$ 4750$, and the Government paid the higher amount to an innocent holder. When the crror was discovered the Government sought to recover from the endorsec bank, although a private drawee would have been barred from recovery because the drawer and drawee were the same. The Government argued that the integrity of the public fisc was at stake and that "the hand that drew and the hand that was to pay were not the same," $i d$. at 534, but the Court denied recovery because "[t]he United States does business on business terms." Id. Accord, Keck v. Browne, 314 Ky. 151, 234 S.W.2d 183 (1950). See also United States v. Hadden, 192 F.2d 327 (6th Cir. 1951) (absent clear contrary statutory intent, Government suit to recover money paid by mistake must be ruled by general law of restitution). It would appear to follow that if a "mistake" has become embodicd in a final judgment there is even less reason to permit the Government to retrieve its error, and the Government has indeed been held bound by procedural errors of its counsel. E.g., United States v. Eastport S.S. Corp., 255 F.2d 795 (2d Cir. 1958) (failure to assert compulsory counterclaim in prior suit in Court of Claims bars later suit for damages); cf. In re 73rd Precinct Station House, 329 F. Supp. 1175 (S.D.N.Y. 1971) (remanding action to state court because Government's removal petition untimely, Government waived right to remove, and action not within original jurisdiction of district courts). But cf. White v. Adler, 289 N.Y. 34, 44, 43 N.E.2d 798, 802 (1942) (liability created by state should not be extinguished by application of rule of merger where mistake by state official led to suit on less than full obligation).

254. 500 F.2d 701 (6th Cir. 1974), cert. denied, 421 U.S. 991 (1975).

255. Id. at 704. The State of Ohio was not a named defendant in the original action, but the Governor was, and the Attorney General had managed the defense. The judgment for fees was entered against the State, but at no point was the fact that it was not formally a party deemed crucial to the power vel non of the district court to enter judgment against the state. See id. at 704-05 \& n.3.

256. It was over eight months after the judgment for the fees was entered. $I d$. at 704 .

257. Fed. R. Civ. P. 60(b); see note 45 supra. 
tion. ${ }^{258}$ But the Sixth Gircuit reversed and held the judgment void..59 The court remarked that the state's Eleventh Amendment rights could, under Ohio law, be waived only by the legislature, ${ }^{260}$ and concluded that the state's delay in attacking the judgment was therefore immaterial. ${ }^{261}$

If the courts of the United States could under no circumstances entertain proceedings against a state, then it might be possible to regard Jordan as a legitimate holding of an absolute lack of judicial power. But the federal courts are not so restricted, ${ }^{262}$ and the proceeding for fees was ancillary to a reapportionment proceeding over which the court had unquestioned jurisdiction. ${ }^{263}$ It is therefore difficult to see how the decision in Jordan can be maintained on grounds of lack of judicial power, and this difficulty is compounded by a comparison with In re Four Seasons Securities Laws Litigation, ${ }^{264}$ which also involved negligence in the Ohio Attorney General's office.

Four Seasons was one phase of complicated litigation charging violations of the securities laws. Numerous actions were consolidated and transferred to the Western District of Oklahoma, where the consolidated action was certified as a class action. Ohio was a member of a plaintiff class in the consolidated action and was plaintiff both in a related suit in its own courts and in an untransferred suit in the Southern District of Ohio. Settlement negotiations began in the consolidated action, and "[v]arious attorneys for the State of Ohio, including the Attorney General, participated in one or more of these discussions ...."265 An agreement was reached, apparently founded in part on the assumption that Ohio would opt out as a class member and proceed with the pending suits in the Ohio courts. Notice of the settlement reached the Attorney General's office, but, due to a misunderstanding among the lawyers there, Ohio failed to opt out. When it received notice of entry of judgment it did not appeal, but

258. See 500 F.2d at 710. The other bases for the district court's holding are not given; presumably it felt there was no immunity to begin with.

259. Id. at 704, 710. The court relied on Edelman v. Jordan, 415 U.S. 651 (1974), which denied, on Eleventh Amendment grounds, "restitution" of welfare benefits withheld in contravention of federal regulations.

260. $500 \mathrm{~F} .2 \mathrm{~d}$ at 708 .

261. Id. at 710. The court also held that res judicata was not a bar to a 60(b) attack. $I d$. For a discussion of $60(\mathrm{~b})$ attacks arguing that jurisdiction is no more relevant to 60(b) attacks than it is to other attacks, see p. 224 infra.

262. See pp. 217-18 supra.

263. Baker v. Carr, 369 U.S. 186, 198-204 (1962).

264. 502 F.2d 834 (10th Cir.), cert. denied, 419 U.S. 1034 (1974). The full history of the litigation is set out in two opinions of the district court. 59 F.R.D. 667 (W.D. Okla. 1973), rev'd, 502 F.2d 834 (10th Cir.), cert. denied, 419 U.S. 1034 (1974); 58 F.R.D. 19 (IV.D. Okla. 1972).

265. 59 F.R.D. at 673 . 
instead filed a motion to vacate pursuant to Rule 60 (b). The district court granted the motion; the court cited the reasonable explanations for the negligence of Ohio's counsel and the possibility that the state's interests were not adequately protected by the class representatives during the final settlement negotiations. ${ }^{266}$ Neither factor alone was conclusive, but the court decided that "the totality of the evidence requires that Ohio be relieved from the operation of the judgment." ${ }^{20} \bar{t}$ The Tenth Circuit reversed. It read the lower court's opinion as addressing a due process issue, and it found that due process had been satisfied because Ohio had had " "both actual and constructive knowledge of the settlement and ... took no steps to object to [it] prior to the entry of the judgment." "268

The similarity between the circumstances of Jordan and Four Seasons is striking. Both cases involved neglect and delay by Ohio's counsel, which led to entry of a judgment against Ohio's financial interest. In Jordan the district court was held obligated to vacate because the judgment was "void," whereas the district court in Four Seasons was held to have abused its discretion in vacating despite a much lower degree of culpability on the part of counsel for Ohio than was evident in Jordan. ${ }^{269}$ Whatever view is taken of the proper balance to be struck between the need for finality in class actions and the liberal purpose of Rule 60 (b) to accomplish substantial justice, the analyses in Four Seasons, both in the court below and on appeal, are much more to the point than was the mechanical invocation of the voidness doctrine in Jordan. Ohio slept on its rights in Jordan, but the voidness doctrine, in the form of a highly controversial Eleventh Amendment claim, ${ }^{2 \pi 0}$ saved the day. In Four Seasons

266. Id. at 683 .

267. Id. (footnote omitted).

268. 502 F.2d at 844 (quoting Research Corp. v. Asgrow Seed Co., 425 F.2d 1059, 1061 (7th Cir. 1970)).

269. The delay was eight months in Jordan compared with less than a month in Four Seasons. In addition, the district court in Four Seasons found the negligence by Ohio's counsel understandable, if not excusable within the meaning of Rule $60(\mathrm{~b})(1)$. 59 F.R.D. at 679, 683.

270. There has been considerable disagreement among the circuits on the substantive issue under Edelman v. Jordan, 415 U.S. 651 (1974), of the taxability of attorneys' fees as costs in suits against states or state officials, and the position taken by the Sixth Circuit is a minority one. Accord, Skehan v. Board of Trustees, 501 F.2d 31, 44 (3d Cir. 1974) (barring fees on remand if college found to be state agency), vacated, 421 U.S. 983 (1975); Named Individual Members of San Antonio Conservation Soc'y v. Texas Highway Dep't, 496 F.2d 1017, 1026 (5th Cir. 1974) (barring fees under Edelman), cert. denied, 420 U.S. 926 (1975). Contra, Thonen v. Jenkins, 517 F.2d 3, 6-8 (4th Cir. 1975) (granting fecs); Souza v. Travisono, 512 F.2d 1137 (Ist Cir.), vacated, 423 U.S. 809 (1975); Jordan v. Fusari, 496 F.2d 646 (2d Cir. 1974) (Eleventh Amendment claim, waived as to damages, cannot bar claim for fees); Brandenburger v. Thompson, 494 F.2d 885, 888 (9th Cir. 1974) (granting fees against state official acting in official capacity). The question may have been temporarily mooted as a result of the decision in Alyeska Pipeline Serv. Co. v. Wilderness 
Ohio's counsel may well have been "lulled" into misunderstanding the nature of settlement negotiations, ${ }^{271}$ but there was no question of jurisdiction and the state lost. The mechanical nature of the application of the voidness doctrine is typical of the doctrine itself; it provides persuasive evidence that the doctrine not only fails to achieve the goals it sets for itself, but also produces random inequities along the way. Such a doctrine deserves finally to be laid to rest.

\section{Replacing Voidness}

\section{A. Jurisdiction as a Defense on the Merits}

The preceding discussion has indicated that the proper resolution of the tension between finality and justice is not served by treating questions of jurisdiction as questions of power. Instead of retaining a voidness doctrine that permits diversion of discussion to questions of power, courts should return to the principles enunciated in Stoll v. Gottlieb, ${ }^{272}$ Chicot County Drainage District v. Baxter State Bank, ${ }^{273}$ and Durfee v. Duke, ${ }^{274}$ and reject attacks on judgments based on an asserted want of subject-matter jurisdiction in the rendering court. The goal of justice in dispute resolution is adequately served by treating lack of jurisdiction over the subject matter as a defense on the merits, a defense in which the court has an independent interest and can address sua sponte. This approach recognizes and maintains the strong independent interest of the judiciary in preserving jurisdictional allocations, but it does not lose sight of the nature of judicial power. When a member of the judicial system has entered a judgment in proceedings conducted in accord with due process, and that judgment has become final, the judicial process has ended. The power to settle disputes is granted to the judicial system as a whole; which of its members has spoken is immaterial after final settlement.

The operational implications of treating jurisdiction as a defense accord well with this Note's theory of judicial power. ${ }^{275}$ It is a com-

Soc'y, 421 U.S. 240 (1975), restricting the general power of federal courts to grant attorneys' fees. See, e.g., Skehan v. Board of Trustees, 421 U.S. 983 (1975), vacaling and remanding 501 F.2d 31 (3d Cir. 1974). But the conflict is raging again since the passage of the Civil Rights Attorney's Fees Awards Act of 1976, Pub. L. No. 94-559, 90 Stat. 2641 (amending 42 U.S.C.A. $\$ 1988$ (West June, 1977 Pamph.)). Compare Skehan v. Board of Trustees, 46 U.S.L.W. 2045 (M.D. Pa. July 20, 1977) (denying fecs) with Finncy v. Hutto, 548 F.2d 740 (8th Cir. 1977) (granting fees) and Wade v. Mississippi Coop. Extension Serv., 424 F. Supp. 1242 (N.D. Miss. 1976) (granting fees).

271. 59 F.R.D. at 683 .

272. 305 U.S. 165 (1938).

273. 308 U.S. 371 (1940).

274. 375 U.S. 106 (1963).

275. There is one technical problem with this treatment. A dismissal of a claim "on the merits" operates as an adjudication in favor of defendant and invokes the rule 
monplace that a defense on the merits may not serve as a basis for an attack on a judgment. ${ }^{276}$ By contrast, Stoll, Chicot, and Durfee treat the question of a judgment's validity as an issue apart from the judgment itself; that is, an issue that might well be foreclosed by the judgment itself but one that, as Kalb and Fidelity show, need not be..27 This treatment will frequently lead to the same results as the defense-on-the-merits approach, but it does not give effect to the full implications of judicial power. A judgment of a member of the judicial system simply is valid unless there is some underlying due process violation.

of bar, SECOND RESTATEMENT $\$ 48$, comment a, but a dismissal for want of jurisdiction does not, id. $\$ 48.1(1)(a)$. It is clearly undesirable for a plaintiff who brought his claim in the wrong forum to be barred from then bringing it in an appropriate forum. But that would not happen under the proposal put forward here.

In order to determine what is barred by an adjudication for defendant, it is necessary to determine what claim was brought. But if one includes the jurisdiction of the forum as an element of the claim, which is the proposal being made here, then a claim arising out of the same transaction but brought in a different forum is to some extent a different claim than the original one. Thus, a state court dismissal of a patent claim on the ground that the jurisdiction over such a claim is exclusively federal extinguishes only the right to bring that claim in any state court. On the other hand, where jurisdictional language is used to withdraw substantive rights (for example, the legislative overruling of the Portal-to-Portal cases, discussed at HART \& WechSLER 322-24), a dismissal for "want of jurisdiction" extinguishes the entire substantive claim. The rules of claim preclusion, see note 119 supra, are easily flexible enough to handle this problem.

There is another and perhaps simpler way to analyze this problem, which leads to the same result. Claim preclusion deals with things that could have been litigated, and a dismissal for want of subject-matter jurisdiction is precisely a statement as to what could and could not have been litigated. Therefore, in order to determine what is precluded, one need only determine the basis for dismissal.

276. See F. JAMEs, supra note 1, at 570; First Restatement $\$ 47$, comment a; Second Restatement $\$ 47(\mathrm{~b})$. The existence of a meritorious defense, however, is a prerequisite to some forms of attack. See F. JAMEs, supra note 1, at 546.

277. The Court has used different modes of analysis in different cases, and its rules have been somewhat ad hoc. In Stoll and Durfee the emphasis was strongly on the issue preclusion aspects; the jurisdictional issues had been litigated thoroughly and there was therefore no justification for reopening them. Durfee v. Duke, 375 U.S. 106, 115 (1963); Stoll v. Gottlieb, 305 U.S. 165, 172 (1938). On the other hand, Chicot and the divorce cases-Sherrer and Coe-emphasize opportunity to litigate, which is the cornerstone of claim preclusion. Sherrer v. Sherrer, 334 U.S. 343, 351-52 (1948); Chicot County Lirainage Dist. v. Baxter State Bank, 308 U.S. 371, 378 (1940). It is likely that the issue preclusion rule is the correct interpretation of the Court's opinions in this area, if one may regard opinions spanning twenty-five years and a changing Court as susceptible to one "correct" interpretation. "Actually litigated" is the hallmark of issue preclusion, see SECOND REsTATEMENT $\$ 68$, and in the three cases raising the most serious policy implications-Durfee, Kalb, and Fidelily-the question of whether the issue had been litigated may have been decisive. See Durfee v. Duke, 375 U.S. 106, 113-14 \& n.12 (1963). Moreover, issue preclusion will occasionally be denied simply because the shape of the new litigation suggests that a redetermination would be appropriate. E.g., Henderson v. Bardahl Int'l Corp., 72 W'ash. 2d 109, 119, 491 P.2d 961, 967-68 (1967) (collateral estoppel denied to prevent "windfall" recovery). See SEcond Restatement \$ 68.1(b)(ii); pp. 206-07 \& notes 197-200 supra. Thus the Court's absolutist position in Kalb may be seen to fit, if perhaps somewhat uneasily, with modern views of issue preclusion. 


\section{B. Applying the Test: Federal Rule $60(b)(4)$}

Rule $60(b)(4)^{2 \pi 8}$ expressly incorporates the voidness doctrine into the Federal Rules, and it has been held that there is no room for discretion in applying that subsection. ${ }^{279}$ It will therefore be instructive to consider the defense-on-the-merits approach as applied to postjudgment motions to vacate, brought in the court that rendered the judgment, pursuant to Rule 60(b) or similar state practice. ${ }^{2 s 0}$ The institutional and philosophical bases of preclusion theory both incline toward granting such attacks favored status. Proceedings in the rendering court avoid intrasystem squabbling and eliminate the problem of having to choose between two outstanding determinations of an issue. But it does not follow that a 60(b) attack should automatically permit a reopening of the question of the rendering court's jurisdiction, for there is still a final judgment to contend with.

There is no reason that the criteria for reaching jurisdictional questions on 60 (b) motions should be any different from those for reaching any other defense. The first three subsections of Rule 60(b) are derived from equity practice ${ }^{2 s 1}$ and provide common and sensible reasons for reopening judgments-mistake, fraud, new evidence. They focus the inquiry where it belongs: why was the issue not raised before judgment? Moreover, $60(\mathrm{~b})(6)$, which permits "other reasons" to justify vacation of the judgment, provides sufficient flexibility to meet unforeseen circumstances. ${ }^{282}$ Hence if $60(\mathrm{~b})(4)$ is to be kept, the interpretation of "voidness" under the Rule can be limited to due process violations. Jordan and Four Seasons demonstrate the folly of a broader interpretation. ${ }^{283}$

The approach described in this Note, properly applied, should result in fewer successful attacks on judgments, in or out of the rendering court. The attacks that do succeed, however, will be more likely than at present to do so for reasons of fundamental justice.

278. FED. R. Civ. P. 60(b)(4). See note 45 supra.

279. See, e.g., Jordan v. Gilligan, 500 F.2d 701 (6th Cir. 1974). Cf. Heckathorn v. Heckathorn, 77 N.M. 369, 423 P.2d 410 (1967) (decided under N.M.R. Civ. P. 60(b)(4)).

280. E.g., Cal. Civ. Proc. Code $\S 473$ (West 1970); N.Y. Civ. Prac. Law Rule 5015 (McKinney Supp. 1975).

281. See 2 J. SroRY, supra note 33 , at $172-73$ (mistake, fraud, and accident).

282. This analysis applies equally as well to default judgments as to other judgments. Courts are "disposed to vacate default judgments if they are presented with any reasonable basis on which to do so." Sicgel, Practice Commentary C3215:24, in N.Y. Civ. Prac. LAW $\$ 3215$, at 880 (McKinney 1970). Given this policy, it is difficult to sec why a litigant who can show no such basis ought to be granted relief.

283. Professor Dobbs has advanced similar views concerning a $60(\mathrm{~b})$ attack. See Beyond Bootstrap, supra note 79, at 495-99. 